U.S. Department of the Interior

U.S. Geological Survey

\title{
Ground-Water, Surface-Water, and Water-Chemistry Data, Black Mesa Area, Northeastern Arizona-2003-04
}

Open-File Report 2005-1080

Prepared in cooperation with the

ARIZONA DEPARTMENT OF WATER RESOURCES and BUREAU OF INDIAN AFFAIRS

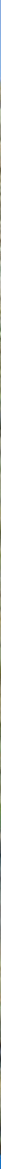


This page left blank intentionally. 


\section{Ground-Water, Surface-Water, and Water-Chemistry Data, Black Mesa Area, Northeastern Arizona-2003-04}

By Margot Truini, J.P. Macy, and T.J. Porter

Prepared in cooperation with

the BUREAU OF INDIAN AFFAIRS and the ARIZONA DEPARTMENT OF WATER RESOURCES

Open-File Report 2005-1080 


\section{U.S. Department of the Interior \\ Gale A. Norton, Secretary \\ U.S. Geological Survey \\ Charles G. Groat, Director}

U.S. Geological Survey, Reston, Virginia: 2005

For sale by U.S. Geological Survey, Information Services
Box 25286, Denver Federal Center
Denver, CO 80225
For more information about the USGS and its products:
Telephone: 1-888-ASK-USGS
World Wide Web: http://www.usgs.gov/

Any use of trade, product, or firm names in this publication is for descriptive purposes only and does not imply endorsement by the U.S. Government.

Although this report is in the public domain, permission must be secured from the individual copyright owners to reproduce any copyrighted materials contained within this report.

Suggested citation:

Truini, Margot, Macy, J.P., and Porter, T.J., 2005, Ground-water, surface-water, and water-chemistry data, Black Mesa area, northeastern Arizona_-2003-04: U.S. Geological Survey Open-File Report 2005-1080, 44 p. 


\section{Contents}

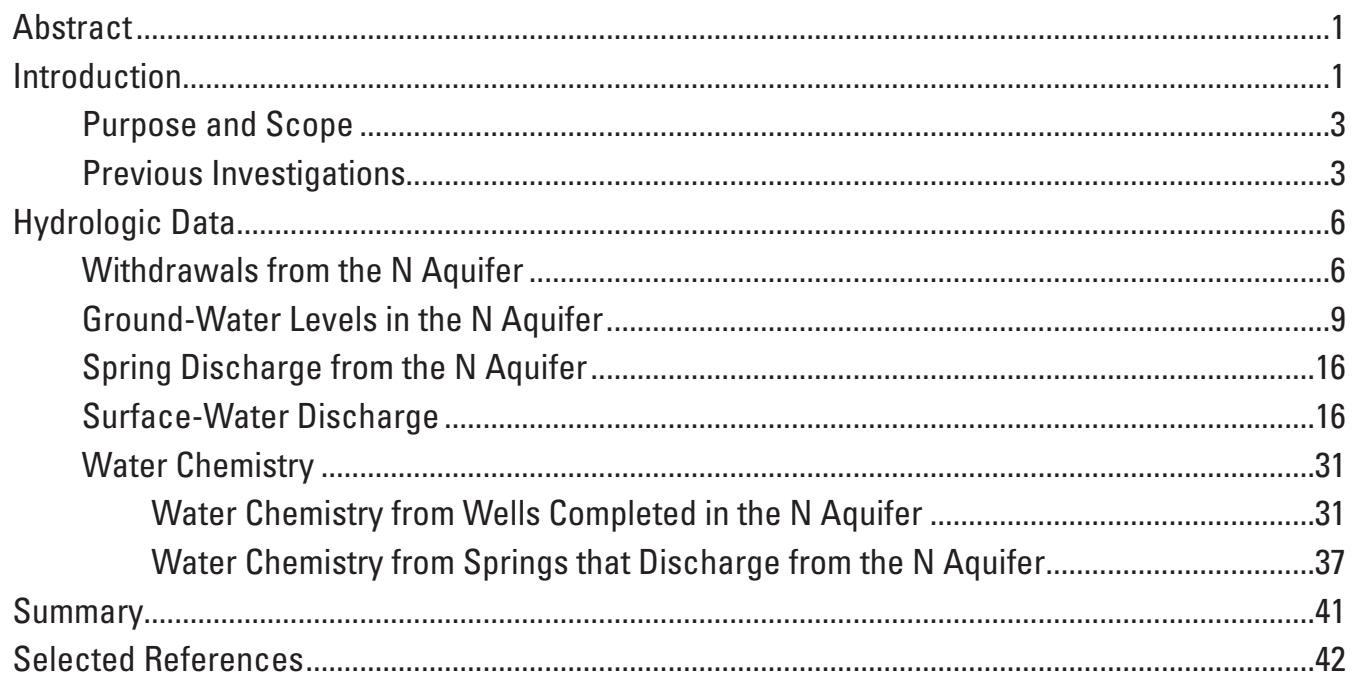

\section{Figures}

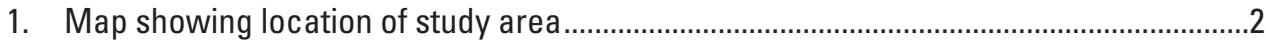

2. Diagram showing rock formations and hydrogeologic units of the

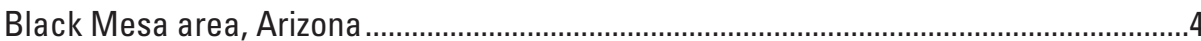

3. Graph showing withdrawals from the $\mathrm{N}$ aquifer, Black Mesa area,

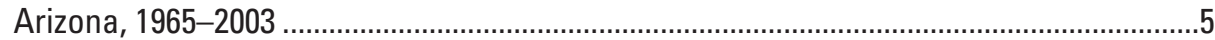

4. Map showing locations of well systems monitored for withdrawals from the $\mathrm{N}$ aquifer, Black Mesa area, Arizona, 2003 ................................................................7

5. Map showing water-level changes in $\mathrm{N}$ aquifer wells from the prestress period to 2004, Black Mesa area, Arizona .....................................................................1

6. Graph showing annual median water-level changes for observation wells completed in the N aquifer, Black Mesa area, Arizona, 1983-2004 ..............................15

7. Graphs showing observed water levels (1950-2004) in annual observation-well network, Black Mesa area, Arizona.

8. Graph showing observed water-level changes in continuous-record observation wells, BM1-BM6, Black Mesa area, Arizona ................................................21

9. Map showing surface-water and water-chemistry data-collection sites, Black Mesa area, Arizona, 2003-04.

10. Graph showing discharge from selected springs, Black Mesa area, Arizona, 1987-2004 


\section{Figures-Continued}

11. Graphs showing annual precipitation at Betatakin, Arizona, and streamflow characteristics at Moenkopi Wash (09401260), Laguna Creek (09379180), Dinnebito Wash (09401110), and Polacca Wash (09400568), Black Mesa area, Arizona.

A. Annual precipitation at Betatakin, Arizona, calendar years, 1976-2002 …....................30

B. Annual discharge for calendar years 1977-2003........................................................30

C. Median discharge for November, December, January, and February for water years 1977-2003...

12. Map showing water chemistry and distribution of dissolved solids in the $\mathrm{N}$ aquifer, Black Mesa area, Arizona, 2004 32

13. Graph showing dissolved-solids concentrations with linear trend lines for water from selected wells, Black Mesa area, Arizona, 1974-2004. .. .37

14. Graph showing dissolved-solids concentrations with linear trend lines for water from selected springs, Black Mesa area, Arizona, 1984-2004

15. Graph showing chloride concentrations with linear trend lines for water from selected springs, Black Mesa area, Arizona, 1982-2004.

\section{Tables}

1. Withdrawals from the $\mathrm{N}$ aquifer, Black Mesa area, Arizona, 1965-2003 ..........................5

2. Identification numbers and names of study wells, 2003-04, Black Mesa area, Arizona

3. Withdrawals from the $\mathrm{N}$ aquifer by well system, Black Mesa area, Arizona, 2003.

4. Flowmeter-test results for selected municipal wells that are completed in the $\mathrm{N}$ aquifer, Black Mesa area, Arizona, 2004

5. Water-level changes in wells completed in the $\mathrm{N}$ aquifer, Black Mesa area, Arizona, prestress period to 2004

6. Well-construction characteristics, depth to top of $\mathrm{N}$ aquifer, and type of data collected for wells in the monitoring program, Black Mesa area, Arizona, 2003-04

7. Median changes in water levels, 2003-04 and prestress period to 2004, Black Mesa area, Arizona.

8. Discharge measurements of selected springs, Black Mesa area, Arizona, 1952-2004

9. Discharge data, Moenkopi Wash at Moenkopi, Arizona (09401260), calendar year 2003

10. Discharge data, Laguna Creek at Dennehotso, Arizona (09379180), calendar year 2003

11. Discharge data, Dinnebito Wash near Sand Springs, Arizona (09401110), calendar year 2003

12. Discharge data, Polacca Wash near Second Mesa, Arizona (09400568), calendar year 2003 


\section{Tables-Continued}

13. Date that data collection began and drainage areas for streamflow-gaging stations, Black Mesa area, Arizona..

14. Physical properties and chemical analyses of water from selected industrial and municipal wells completed in the $\mathrm{N}$ aquifer, Black Mesa area, Arizona, 2004

15. Specific conductance and concentrations of selected chemical constituents in water from industrial and municipal wells completed in the $\mathrm{N}$ aquifer, Black Mesa area, Arizona, 1974-2004.

16. Physical properties and chemical analyses of water from selected springs that discharge from the $\mathrm{N}$ aquifer,Black Mesa area, Arizona, 2004 ....

17. Specific conductance and concentrations of selected chemical constituents in water from selected springs that discharge from the $\mathrm{N}$ aquifer, Black Mesa area, Arizona, 1948-2004.

\section{Conversion Factors and Datums}

\begin{tabular}{lcl}
\hline Multiply & By & To obtain \\
\hline inch (in.) & 2.54 & centimeter $(\mathrm{cm})$ \\
inch (in.) & 25.4 & millimeter $(\mathrm{mm})$ \\
foot (ft) & 0.3048 & meter $(\mathrm{m})$ \\
mile (mi) & 1.609 & kilometer $(\mathrm{km})$ \\
square mile ( $\left.\mathrm{mi}^{2}\right)$ & 2.590 & square kilometer $\left(\mathrm{km}^{2}\right)$ \\
acre-foot $(\mathrm{acre}-\mathrm{ft})$ & 0.001233 & cubic hectometer $\left(\mathrm{hm}^{3}\right)$ \\
cubic foot per second $\left(\mathrm{ft}^{3} / \mathrm{s}\right)$ & 0.02832 & cubic meter per second $\left(\mathrm{m}^{3} / \mathrm{s}\right)$ \\
gallon per minute $(\mathrm{gal} / \mathrm{min})$ & 0.06309 & liter per second $(\mathrm{L} / \mathrm{s})$ \\
gallon per day $(\mathrm{gal} / \mathrm{d})$ & 0.003785 & cubic meter per day $\left(\mathrm{m}^{3} / \mathrm{d}\right)$ \\
\hline
\end{tabular}

Temperature in degrees Celsius $\left({ }^{\circ} \mathrm{C}\right)$ may be converted to degrees Fahrenheit $\left({ }^{\circ} \mathrm{F}\right)$ as follows:

$$
\mathrm{F}=\left(1.8^{\circ} \mathrm{C}\right)+32
$$

Vertical coordinate information is referenced to the National Geodetic Vertical Datum of 1929 (NGVD 29) - a geodetic datum derived from a general adjustment of the first-order level nets of both the United States and Canada, formerly called Sea Level Datum of 1929; horizontal coordinate information is referenced to the North American Datum of 1927 (NAD 27). Altitude, as used in this report, refers to distance above or below NGVD 29. 


\section{ABBREVIATED WATER-QUALITY UNITS}

Chemical concentration and water temperature are given only in metric units. Chemical concentration in water is given in milligrams per liter $(\mathrm{mg} / \mathrm{L})$ or micrograms per liter $(\mu \mathrm{g} / \mathrm{L})$. Milligrams per liter is a unit expressing the solute mass (milligrams) per unit volume (liter) of water. One thousand micrograms per liter is equivalent to 1 milligram per liter. For concentrations less than 7,000 milligrams per liter, the numerical value is about the same as for concentrations in parts per million. Specific conductance is given in microsiemens per centimeter at 25 degrees Celsius $\left(\mu \mathrm{S} / \mathrm{cm}\right.$ at $25^{\circ} \mathrm{C}$ ). 


\title{
Ground-Water, Surface-Water, and Water-Chemistry Data, Black Mesa Area, Northeastern Arizona-2003-04
}

\author{
By Margot Truini, J.P. Macy, and T.J. Porter
}

\section{Abstract}

The $\mathrm{N}$ aquifer is the major source of water in the 5,400-square-mile area of Black Mesa in northeastern Arizona. Availability of water is an important issue in this area because of continued industrial and municipal use, a growing population, and precipitation of about 6 to 14 inches per year.

The monitoring program in the Black Mesa area has been operating since 1971 and is designed to determine the long-term effects of ground-water withdrawals from the $\mathrm{N}$ aquifer for industrial and municipal uses. The monitoring program includes measurements of (1) ground-water pumping, (2) ground-water levels, (3) spring discharge, (4) surface-water discharge, (5) ground-water chemistry, and (6) periodic testing of ground-water withdrawal meters.

In 2003, total ground-water withdrawals were 7,240 acre-feet, industrial withdrawals were 4,450 acrefeet, and municipal withdrawals were 2,790 acre-feet. From 2002 to 2003, total withdrawals decreased by 10 percent, industrial withdrawals decreased by 4 percent, and municipal withdrawals decreased by 20 percent. Flowmeter testing was completed for 24 municipal wells in 2004. The median difference between pumping rates for the permanent meter and a test meter for all the sites tested was -2.9 percent. Values ranged from -10.9 percent at Forest Lake NTUA 1 to +7.8 percent at Rough Rock NTUA 2. From 2003 to 2004, water levels declined in 6 of 12 wells in the unconfined part of the aquifer, and the median change was -0.1 foot. Water levels declined in 7 of 11 wells in the confined part of the aquifer, and the median change was -2.7 feet.

From the prestress period (prior to 1965) to 2003, the median water-level change for 26 wells was -23.2 feet. Median water-level changes were -6.1 feet for 14 wells in the unconfined parts of the aquifer and -72.1 feet for 12 wells in the confined part.

Discharges were measured once in 2003 and once in 2004 at four springs. Discharge stayed the same at Pasture Canyon Spring, increased 9 percent at Moenkopi Spring, decreased 26 percent at an unnamed spring near Dennehotso, and decreased 50 percent at Burro Spring. For the past 12 years, discharges from the four springs have fluctuated; however, an increasing or decreasing trend is not apparent.

Continuous records of surface-water discharge have been collected from 1976 to 2003 at Moenkopi Wash, 1996 to 2003 at Laguna Creek, 1993 to 2003 at Dinnebito Wash, and 1994 to 2003 at Polacca Wash. Median flows for November, December, January, and February of each water year were used as an index of ground-water discharge to those streams. Since 1995, the median winter flows have decreased for Moenkopi Wash, Dinnebito Wash, and Polacca Wash. Since the first continuous record of surface-water discharge in 1997 , there is no consistent trend in the median winter flow for Laguna Creek.

In 2004, water samples were collected from 12 wells and 4 springs and analyzed for selected chemical constituents.

Dissolved-solids concentrations ranged from 100 to 649 milligrams per liter. Water samples from 11 of the wells and from all the springs had less than 500 milligrams per liter of dissolved solids. There are no appreciable time trends in the chemistry of water samples from 7 wells and 2 springs; increasing trends in dissolved-solids and chloride concentrations were evident from the more than 10 years of data for 2 springs.

\section{Introduction}

The Black Mesa study area includes about 5,400 $\mathrm{mi}^{2}$ in northeastern Arizona (fig. 1) and has a diverse topography that includes flat plains, mesas, and incised drainages. Black Mesa is about 2,000 $\mathrm{mi}^{2}$, is bounded by 2,000-foot cliffs on the north and northeast sides, and slopes gradually down in elevation to the south and southwest. Availability of water is an important issue in the study area because of continued ground-water withdrawals, a growing population, and precipitation that averages about 6 to 14 in. per year (U.S. Department of Agriculture, 1999). 


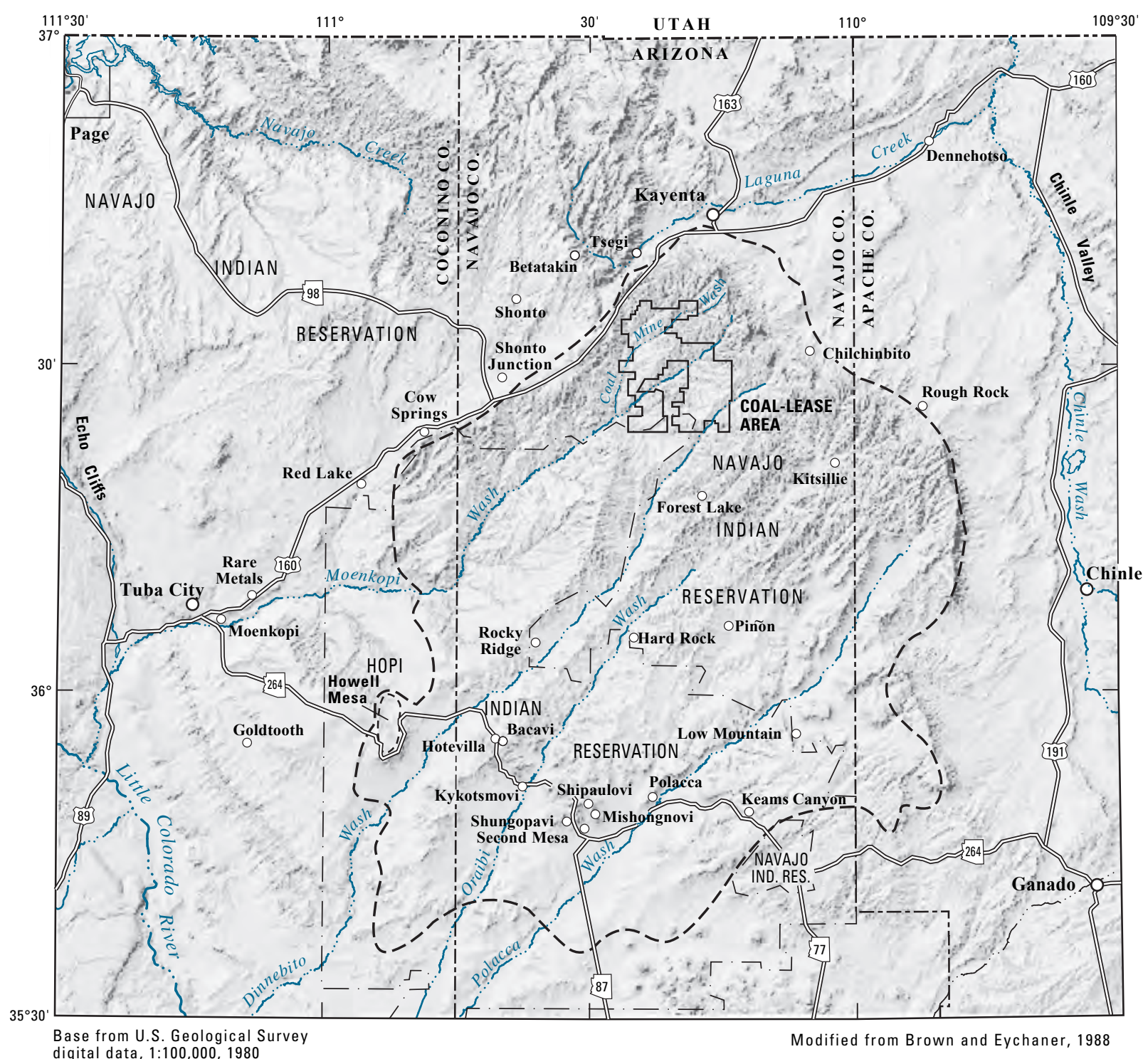
digital data, 1:100,000, 1980 Lambert Conformal Conic projection Standard parallels $29^{\circ} 30^{\prime}$ and $45^{\circ} 30^{\prime}$, central meridian $-111^{\circ} 30^{\prime}$
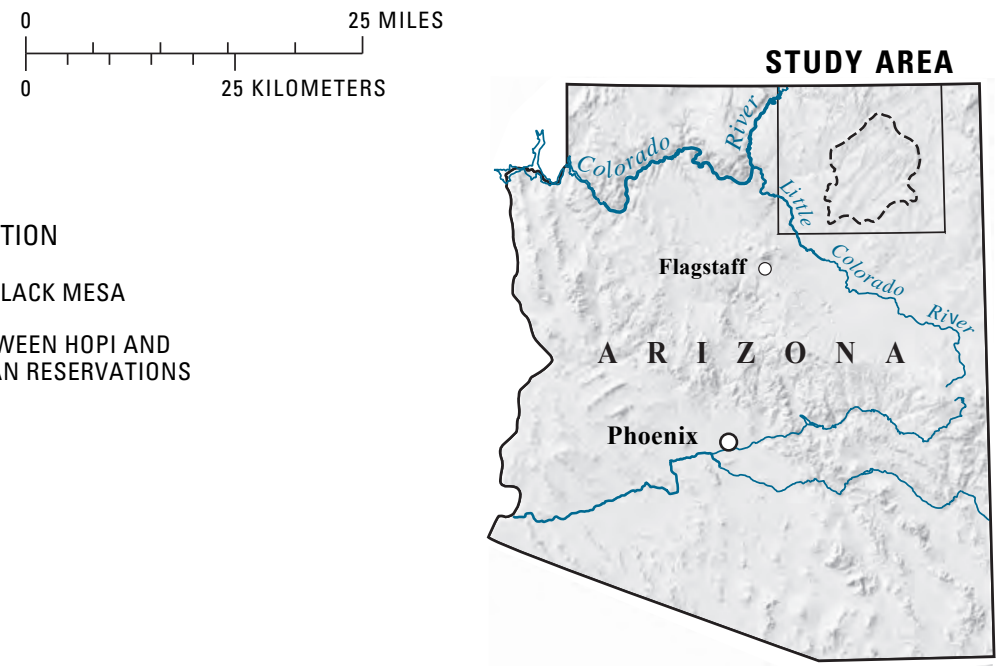

Figure 1. Location of study area. 
The $\mathrm{N}$ aquifer is the major source of water for industrial and municipal uses in the Black Mesa area. It consists of three formations - the Navajo Sandstone, the Kayenta Formation, and the Lukachukai Member ${ }^{1}$ of the Wingate Sandstone- that are hydraulically connected and function as a single aquifer (fig. 2). Within the Black Mesa study area, Peabody Western Coal Company (PWCC) is the principal industrial water user, and the Navajo Nation and Hopi Tribe are the principal domestic and municipal water users.

Withdrawals from the $\mathrm{N}$ aquifer in the Black Mesa area have been increasing during the last 33 years (table 1 and fig. 3). PWCC began operating a strip mine in the northern part of the mesa in 1968. The quantity of water pumped by PWCC increased from about 100 acre-ft in 1968 to a maximum of 4,740 acre-ft in 1982. About 4,450 acre-ft of water was pumped in 2003 by PWCC. Withdrawals for municipal use from the $\mathrm{N}$ aquifer increased from an estimated 250 acre-ft in 1968 to 3,360 acre-ft in 2002, and decreased in 2003 to 2,530 acre-ft. The period before appreciable groundwater withdrawals began for mining or municipal purposes (about 1965), is referred to in this report as the prestress period.

The Navajo Nation and the Hopi Tribe have been concerned about the long-term effects of withdrawals from the $\mathrm{N}$ aquifer on available water supplies, on stream and spring discharge, and on ground-water chemistry. In 1971, these concerns led to the establishment of a monitoring program of the water resources in the Black Mesa area by the U.S. Geological Survey (USGS) in cooperation with the Arizona Department of Water Resources (ADWR). In 1983, the Bureau of Indian Affairs (BIA) joined the cooperative effort. Since 1983, the Navajo Tribal Utility Authority (NTUA); PWCC; the Hopi Tribe; and the Western Navajo Agency, Chinle Agency, and Hopi Agency of the BIA have assisted in the collection of hydrologic data.

\section{Purpose and Scope}

This report presents results of ground-water, surfacewater, and water-chemistry monitoring in the Black Mesa area from January 2003 to September 2004. The monitoring is designed to determine the effects of industrial and municipal pumpage from the $\mathrm{N}$ aquifer on ground-water levels, stream and spring discharge, and ground-water chemistry. Continuous and periodic data are collected for ground water and surface water. Ground-water data include pumpage, water levels, spring discharges, and water chemistry. Surface-water data include discharges at four continuous-record streamflowgaging stations. Flowmeter testing included comparing the pumpage measured by permanent meters at 31 wells to that measured by a calibrated mechanical flowmeter.

\footnotetext{
${ }^{1}$ The name Lukachukai Member was formerly abandoned by Dubiel (1989) and is used herein for report continuity in the monitoring program as it relates to that part of the Wingate Sandstone included in the $\mathrm{N}$ aquifer.
}

\section{Previous Investigations}

Twenty-one progress reports on the monitoring program for the Black Mesa area have been prepared by the USGS (U.S. Geological Survey, 1978; G.W. Hill, hydrologist, written commun., 1982, 1983; Hill, 1985; Hill and Whetten, 1986; Hill and Sottilare, 1987; Hart and Sottilare, 1988, 1989; Sottilare, 1992; Littin, 1992, 1993; Littin and Monroe, 1995a, 1995b, 1996, 1997; Littin and others, 1999; Truini and others, 2000; Thomas and Truini, 2000; Thomas, 2002a, 2002b; and Truini and Thomas, 2004). Most of the data from the monitoring program are contained in these reports. Streamdischarge and periodic water-quality data from Moenkopi Wash collected before the 1982 water year were published by the USGS (1963-64a, b; 1965-74a, b; and 1976-83). Streamdischarge data from water years 1983 to 2003 for Moenkopi Wash and other streams in the Black Mesa area were published in White and Garrett (1984, 1986, 1987, and 1988), Wilson and Garrett $(1988,1989)$, Boner and others (1989, 1990, 1991, 1992), Smith and others (1993, 1994, 1995, 1996, 1997), Tadayon and others (1998, 1999, 2000, 2001), McCormack and others $(2002,2003)$, and Fisk and others (2004). Before the monitoring program, a large data-collection effort in the 1950s resulted in a compilation of well and spring data for the Navajo and Hopi Indian Reservations (Davis and others, 1963).

Many interpretive studies have been done in the Black Mesa area. Cooley and others (1969) made the first comprehensive evaluation of the regional hydrogeology of the Black Mesa area. Eychaner (1983) developed a twodimensional numerical model of ground-water flow in the $\mathrm{N}$ aquifer. Brown and Eychaner (1988) recalibrated the model using a finer grid and revised estimates of selected aquifer characteristics. GeoTrans (1987) also developed a two-dimensional model of the $\mathrm{N}$ aquifer in the 1980s. In the late 1990s, HSIGeoTrans and Waterstone Environmental Hydrology and Engineering (1999) developed a detailed threedimensional numerical model of the $\mathrm{D}$ and $\mathrm{N}$ aquifers.

Kister and Hatchett (1963) made the first comprehensive evaluation of the chemistry of water from wells and springs in the Black Mesa area. HSIGeoTrans (1993) evaluated the major-ion and isotopic chemistry of the $\mathrm{D}$ and $\mathrm{N}$ aquifers. Lopes and Hoffmann (1997) analyzed ground-water ages, recharge, and hydraulic conductivity of the $\mathrm{N}$ aquifer using geochemical techniques. Zhu and others (1998) estimated ground-water recharge using isotopic data and flow estimates from the model developed by GeoTrans (1987). Zhu (2000) estimated recharge again using the same isotopic data, but added numerical flow and transport modeling to the method. Truini and Longsworth (2003) described the hydrogeology of the $\mathrm{D}$ aquifer and movement and ages of ground water using geochemical and isotopic analyses. 


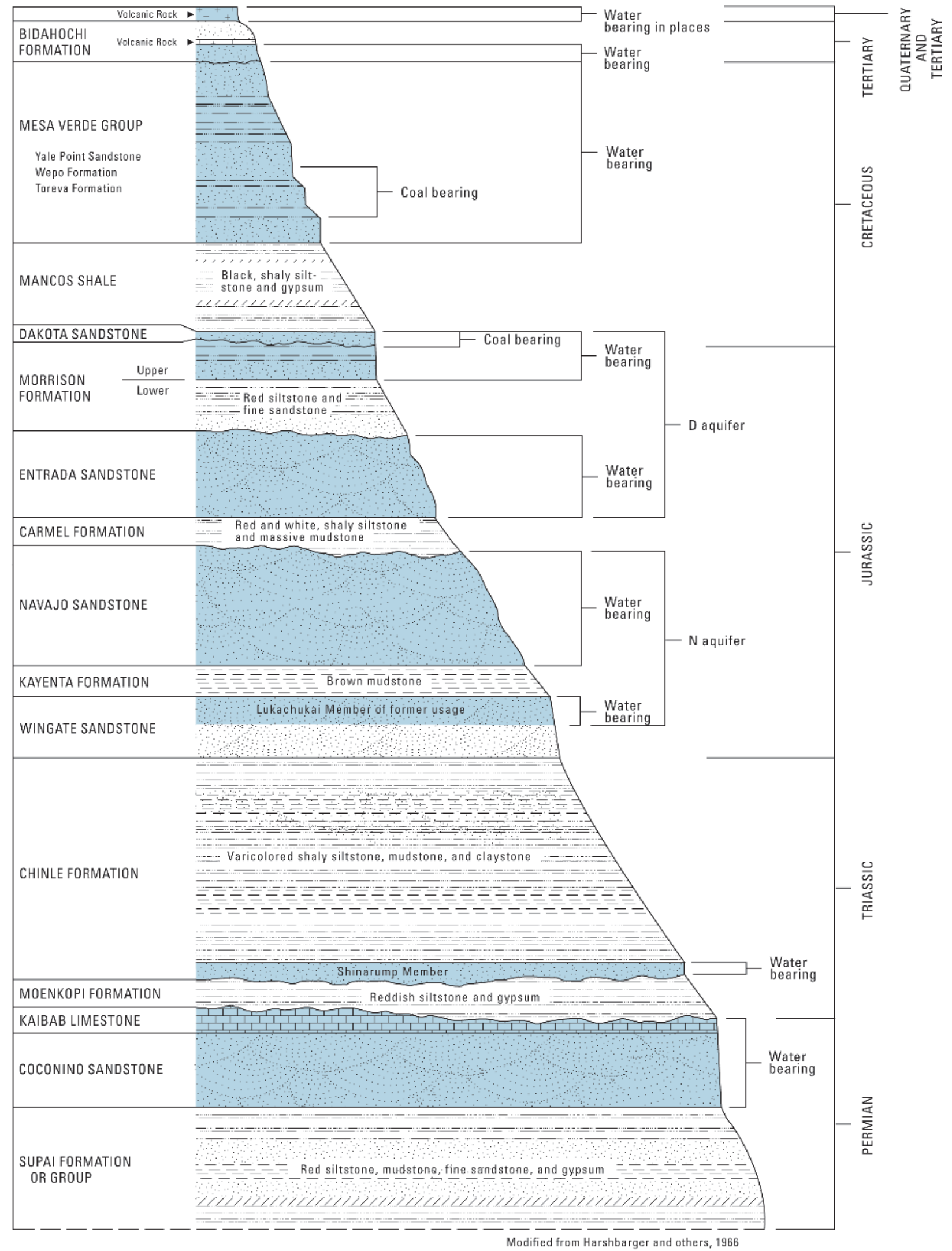

Figure 2. Rock formations and hydrogeologic units of the Black Mesa area, Arizona (not to scale). 
Table 1. Withdrawals from the $\mathrm{N}$ aquifer, Black Mesa area, Arizona, 1965-2003

[Values are rounded to nearest 10 acre-feet. Data for 1965-79 from Eychaner (1983). Total withdrawals in Littin and Monroe (1996) were for the confined part of the aquifer]

\begin{tabular}{|c|c|c|c|c|c|c|c|c|c|}
\hline Year & Industrial $^{1}$ & \multicolumn{2}{|c|}{ Municipal $^{2,3}$} & $\begin{array}{c}\text { Total } \\
\text { withdrawals }\end{array}$ & Year & Industrial $^{1}$ & \multicolumn{2}{|c|}{ Municipal $^{2,3}$} & $\begin{array}{c}\text { Total } \\
\text { withdrawals }\end{array}$ \\
\hline 1965 & 0 & 50 & 20 & 70 & 1984 & 4,170 & 1,070 & 1,400 & 6,640 \\
\hline 1967 & 0 & 120 & 50 & 170 & 1986 & 4,480 & 970 & 1,260 & 6,710 \\
\hline 1968 & 100 & 150 & 100 & 350 & 1987 & 3,830 & 1,130 & 1,280 & 6,240 \\
\hline 1971 & 1,900 & 340 & 150 & 2,390 & 1990 & 3,430 & 1,170 & 1,210 & 5,810 \\
\hline 1972 & 3,680 & 370 & 250 & 4,300 & 1991 & 4,020 & 1,140 & 1,300 & 6,460 \\
\hline 1973 & 3,520 & 530 & 300 & 4,350 & 1992 & 3,820 & 1,180 & 1,410 & 6,410 \\
\hline 1974 & 3,830 & 580 & 360 & 4,770 & 1993 & 3,700 & 1,250 & 1,570 & 6,520 \\
\hline 1979 & 3,500 & 860 & 930 & 5,290 & 1998 & 4,030 & 1,440 & 1,590 & 7,060 \\
\hline 1980 & 3,540 & 910 & 880 & 5,330 & 1999 & 4,210 & 1,420 & 1,480 & 7,110 \\
\hline 1981 & 4,010 & 960 & 1,000 & 5,970 & 2000 & 4,490 & 1,610 & 1,640 & 7,740 \\
\hline 1982 & 4,740 & 870 & 960 & 6,570 & 2001 & 4,530 & 1,490 & 1,660 & 7,680 \\
\hline \multirow[t]{2}{*}{1983} & 4,460 & 1,360 & 1,280 & 7,100 & 2002 & 4,640 & 1,500 & 1,860 & 8,000 \\
\hline & & & & & 2003 & 4,450 & 1,350 & 1,440 & 7,240 \\
\hline
\end{tabular}

${ }^{1}$ Metered pumpage from the confined part of the aquifer by Peabody Western Coal Company.

${ }^{2}$ Does not include withdrawals from the wells equipped with windmills.

${ }^{3}$ Includes estimated pumpage, 1965-73, and metered pumpage, 1974-79, at Tuba City; metered pumpage at Kayenta and estimated pumpage at Chilchinbito, Rough Rock, Piñon, Keams Canyon, and Kykotsmovi before 1980; metered and estimated pumpage furnished by the Navajo Tribal Utility Authority and the Bureau of Indian Affairs and collected by the U.S. Geological Survey, 1980-85; and metered pumpage furnished by the Navajo Tribal Utility Authority, the Bureau of Indian Affairs, various Hopi Village Administrations, and the U.S. Geological Survey, 1986-2000.

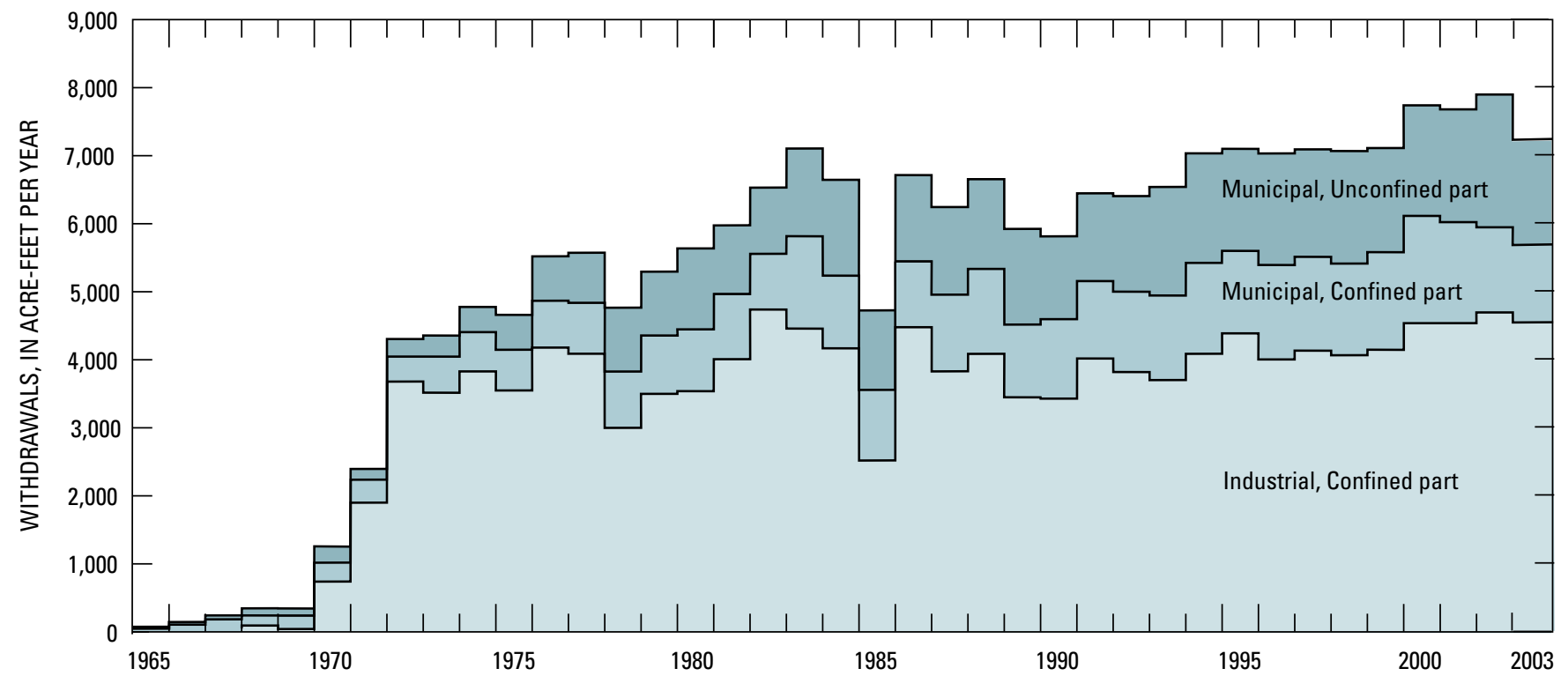

Figure 3. Withdrawals from the N aquifer, Black Mesa area, Arizona, 1965-2003. 


\section{Hydrologic Data}

In 2003-04, the Black Mesa monitoring program included metering and estimating ground-water withdrawals, measuring depth to ground water, measuring discharge in streams and springs, collecting and analyzing water samples from wells and springs, and periodic testing of flowmeters for accuracy. Ground-water withdrawals from 36 well systems, water levels at 6 observation wells, and surface-water discharge at 4 sites were monitored continuously during this period. Continuous recorders at three of the six observation wells were upgraded for telemetry, and the water-level data from these wells are available on the World Wide Web (http://waterdata.usgs.gov/az/nwis/rt). Annual measurements were made of discharge at 4 springs and ground-water levels at 26 wells. Spring discharges and ground-water levels were measured between March and May 2004. Ground-water samples were collected from 12 wells and 4 springs in
March-May 2004 and analyzed for chemical constituents. Identification information for the 51 wells used for water-level measurements and water-quality sampling is shown in table 2 .

\section{Withdrawals from the $\mathbf{N}$ Aquifer}

Withdrawals from the $\mathrm{N}$ aquifer are separated into three categories: (1) industrial withdrawals from the confined part of the aquifer, (2) municipal withdrawals from the confined part of the aquifer, and (3) municipal withdrawals from the unconfined parts of the aquifer (table 1 and fig. 3 ). The industrial category includes eight wells in the well field of PWCC in northern Black Mesa (fig. 4). The BIA, NTUA, and Hopi Tribe operate about 70 municipal wells that are combined into 28 well systems (fig. 4). Withdrawals from the $\mathrm{N}$ aquifer were compiled primarily on the basis of metered data (tables 1 and 3 ).

Table 2. Identification numbers and names of study wells, 2003-04, Black Mesa area, Arizona

[Dashes indicate no data]

\begin{tabular}{|c|c|c|c|c|c|}
\hline $\begin{array}{l}\text { U.S. Geological Survey } \\
\text { identification number }\end{array}$ & Common name or location & $\begin{array}{l}\text { Bureau of } \\
\text { Indian Affairs } \\
\text { site number }\end{array}$ & $\begin{array}{l}\text { U.S. Geological Survey } \\
\text { identification number }\end{array}$ & Common name or location & $\begin{array}{l}\text { Bureau of } \\
\text { Indian Affairs } \\
\text { site number }\end{array}$ \\
\hline 355023110182701 & Keams Canyon PM2 & --- & 363130110254501 & Peabody 8 & -- \\
\hline 355034110183001 & Keams Canyon PM3 & --- & 362406110563201 & White Mesa Arch & $1 \mathrm{~K}-214$ \\
\hline 355215110375001 & Kykotsmovi PM2 & --- & 362418109514601 & Rough Rock PM5 & --- \\
\hline 355236110364501 & Kykotsmovi PM3 & --- & 362647110243501 & Peabody 4 & --- \\
\hline 355428111084601 & Goldtooth & $3 \mathrm{~A}-28$ & 362823109463101 & Rough Rock & $10 \mathrm{R}-119$ \\
\hline 355518110400301 & Hotevilla PM1 & --- & 362936109564101 & BM observation well 1 & $8 \mathrm{~T}-537$ \\
\hline 355638110060401 & Low Mountain PM2 & --- & 363013109584901 & Sweetwater Mesa & $8 \mathrm{~K}-443$ \\
\hline 355648110475501 & Howell Mesa & $6 \mathrm{H}-55$ & 363103109445201 & Rough Rock & 9Y-95 \\
\hline 360418110352701 & Rocky Ridge PM2 & --- & 363232109465601 & Rough Rock & $9 Y-92$ \\
\hline 360527110122501 & Piñon NTUA 1 & --- & 363309110420501 & Shonto & $2 \mathrm{~K}-300$ \\
\hline 360614110130801 & Piñon PM6 & --- & 363423110305501 & Shonto Southeast & $2 \mathrm{~T}-502$ \\
\hline 360734111144801 & Tuba City & 3T-333 & 363558110392501 & Shonto PM2 & --- \\
\hline 360904111140201 & Tuba City NTUA 1 & 3T-508 & 363727110274501 & Long House Valley & $8 \mathrm{~T}-510$ \\
\hline 360918111080701 & Tuba City Rare Metals 2 & --- & 363850110100801 & BM observation well 2 & 8T-538 \\
\hline 360924111142201 & Tuba City NTUA 3 & --- & 361933110565001 & Red Lake PM 1 & -- \\
\hline 360953111142401 & Tuba City NTUA 4 & $3 \mathrm{~T}-546$ & 364226110171701 & Kayenta West & $8 \mathrm{~T}-541$ \\
\hline 361225110240701 & BM observation well 6 & --- & 364248109514601 & Northeast Rough Rock & $8 \mathrm{~A}-180$ \\
\hline 361737110180301 & Forest Lake NTUA 1 & $4 \mathrm{~T}-523$ & 364338110154601 & BM observation well 3 & $8 \mathrm{~T}-500$ \\
\hline
\end{tabular}




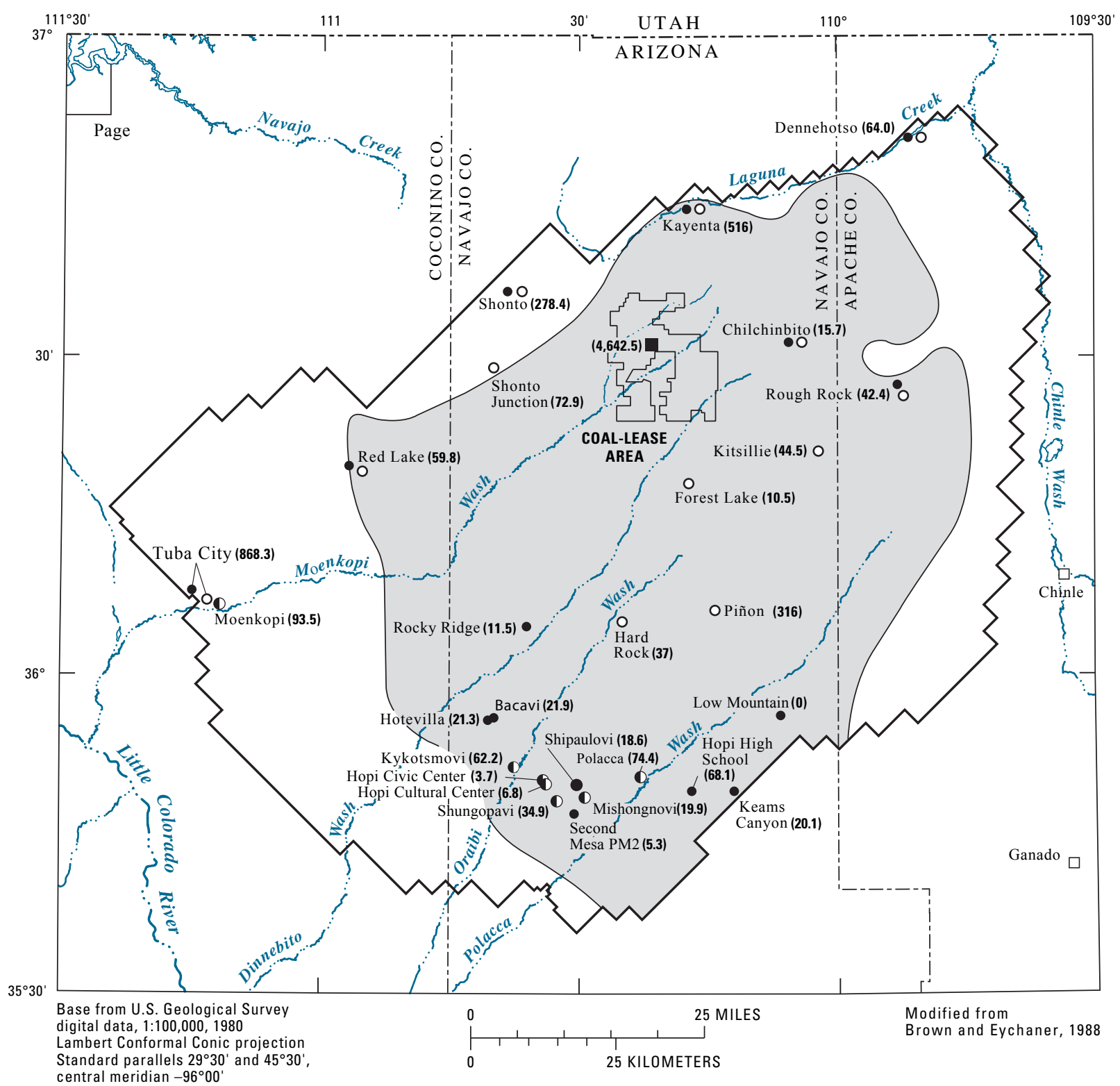

EXPLANATION

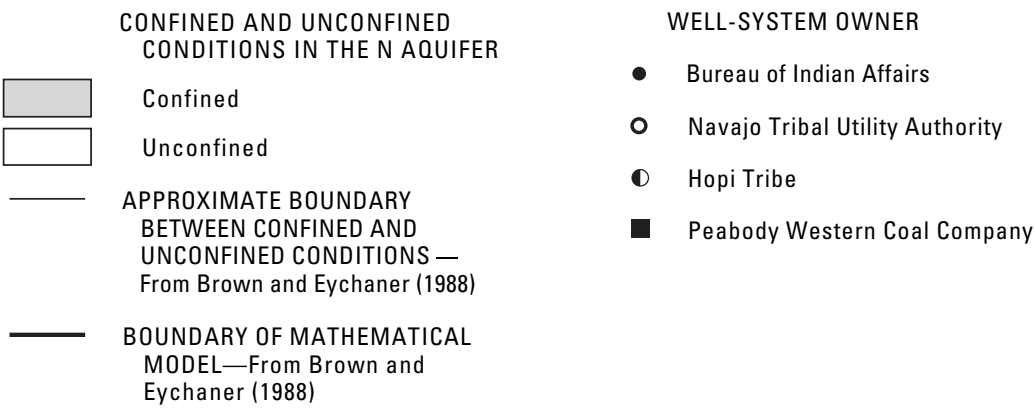

Figure 4. Locations of well systems monitored for withdrawals from the $\mathrm{N}$ aquifer, Black Mesa area, Arizona, 2003. 
Table 3. Withdrawals from the $\mathrm{N}$ aquifer by well system, Black Mesa area, Arizona, 2003

[Withdrawals, in acre-feet, are from flowmeter measurements. BIA, Bureau of Indian Affairs; NTUA, Navajo Tribal Utility Authority; USGS, U.S. Geological Survey; Peabody, Peabody Western Coal Company; Hopi, Hopi Village Administrations]

\begin{tabular}{|c|c|c|c|c|}
\hline \multirow{2}{*}{$\begin{array}{c}\text { Well system } \\
\text { (one or more wells) }\end{array}$} & \multirow[b]{2}{*}{ Owner } & \multirow[b]{2}{*}{ Source of data } & \multicolumn{2}{|c|}{ Withdrawals } \\
\hline & & & Confined aquifer & Unconfined aquifer \\
\hline Chilchinbito & BIA & USGS/BIA & 3.9 & \\
\hline Dennehotso & BIA & USGS/BIA & & 22.6 \\
\hline Hopi High School & BIA & USGS/BIA & 68.1 & \\
\hline Hotevilla & BIA & USGS/BIA & 21.3 & \\
\hline Kayenta & BIA & USGS/BIA & 45.4 & \\
\hline Low Mountain & BIA & USGS/BIA & ${ }^{1} 0$ & \\
\hline Piñon & BIA & USGS/BIA & ${ }^{1} 0$ & \\
\hline Red Lake & BIA & USGS/BIA & & 8.4 \\
\hline Rocky Ridge & BIA & USGS/BIA & 11.5 & \\
\hline Rough Rock & BIA & USGS/BIA & 34.3 & \\
\hline Chilchinbito & NTUA & USGS/NTUA & 11.8 & \\
\hline Dennehotso & NTUA & USGS/NTUA & & 41.4 \\
\hline Forest Lake & NTUA & USGS/NTUA & 10.2 & \\
\hline Hard Rock & NTUA & USGS/NTUA & 37.0 & \\
\hline Kayenta & NTUA & USGS/NTUA & 470.5 & \\
\hline Kitsillie & NTUA & USGS/NTUA & 44.5 & \\
\hline Piñon & NTUA & USGS/NTUA & 316 & \\
\hline Red Lake & NTUA & USGS/NTUA & & 51.4 \\
\hline Rough Rock & NTUA & USGS/NTUA & 8.1 & \\
\hline Shonto & NTUA & USGS/NTUA & & 117.7 \\
\hline Kykotsmovi & Hopi & USGS/Hopi & 62.2 & \\
\hline Mishongnovi & Hopi & USGS/Hopi & 19.9 & \\
\hline Moenkopi & Hopi & USGS/Hopi & & 93.5 \\
\hline Polacca & Hopi & USGS/Hopi & 374.4 & \\
\hline Shipaulovi & Hopi & USGS/Hopi & 18.6 & \\
\hline Shungopovi & Hopi & USGS/Hopi & 34.9 & \\
\hline
\end{tabular}

${ }^{1}$ Well taken out of service.

${ }^{2}$ Industrial pumpage.

${ }^{3}$ Estimated. Well PM4 not metered. Annual pumpage from PM4 was estimated as 40 acre-feet on the basis of previous metered data and a per capita consumption of 40 gallons per day. Pumping from the remaining wells (PM5 and PM6) may include some water from the D aquifer. 
Withdrawals from wells equipped with windmills are not measured in this monitoring program. About 270 windmills in the Black Mesa area withdraw water from the D and $\mathrm{N}$ aquifers, and estimated total withdrawals by the windmills are about 65 acre-ft/yr (HSIGeoTrans, Inc. and Waterstone Environmental Hydrology and Engineering, Inc., 1999). This amount is less than 1 percent of the total annual withdrawal from the $\mathrm{N}$ aquifer.

In 2003, the total ground-water withdrawal from the $\mathrm{N}$ aquifer was about 7,240 acre-ft (table 1 ), which is about a 10-percent decrease from the total withdrawal in 2002. Withdrawals for municipal use from the confined part of the aquifer totaled 1,350 acre-ft, which is about a 10-percent decrease from 2002. Withdrawals for municipal use from the unconfined parts of the aquifer totaled 1,440 acre-ft, which is about a 23-percent decrease from 2002. Withdrawals for industrial use totaled 4,450 acre-ft, which is a 4-percent decrease from 2002.

Withdrawals from the $\mathrm{N}$ aquifer have been increasing since the 1970s (table 1 and fig. 3). Total withdrawals increased by about 12 percent per year from the mid-1960s to 2003 - from the mid-1960s to 1979 , the increase was 28 percent per year. Municipal withdrawals increased by about 20 percent per year in the 1970s, by about 4 percent per year in the 1980 s, by about 2 percent per year in the 1990 s, and decreased by about 2 percent per year from 2000 to 2003 .

In the 1970s, industrial withdrawals were about 70 percent of the total withdrawals each year. With the increase in municipal withdrawals during the last 30 years, industrial withdrawals, as a percentage of total withdrawals, have declined to an average of about 60 percent per year in the 1990s through 2003.

In an effort to improve and ensure the accuracy of ground-water withdrawal data, a quality-assurance program was begun in 1985 for withdrawal data from industrial and municipal wells completed in the $\mathrm{N}$ aquifer. Nearly all industrial and municipal wells in the study area are equipped with totalizing flowmeters to measure ground-water withdrawals. The flowmeters on the municipal wells are tested about every 5 years by measuring pumpage with a calibrated mechanical flowmeter and comparing the measured pumpage to the metered pumpage. For the purpose of this study, the allowable difference between the discharge measured by the permanent totalizing flowmeter and the test meter is 10 percent.

Flowmeter testing was done on approximately one-third of the wells ( 31 wells were visited and 24 wells were tested) during June 2004 (table 4). Most of the remaining municipal wells were tested in 2003 (Truini and Thomas, 2004). The median percent difference between pumping rates for the permanent meter and the test meter for all the sites tested was -2.9 percent. Values ranged from -10.9 percent at Forest Lake NTUA 1 to +7.8 percent at Rough Rock NTUA 2 (table 4). Only the value for Forest Lake NTUA 1 exceeded the 10-percent allowable difference.

\section{Ground-Water Levels in the N Aquifer}

Ground water in the $\mathrm{N}$ aquifer is under confined conditions in the central part of the study area and under unconfined or water-table conditions around the periphery (fig. 5). The ground water generally moves radially from the recharge areas near Shonto to the southwest towards Tuba City, the south towards the Hopi Reservation, and the east towards Rough Rock and Dennehotso (Eychaner, 1983).

Ground-water levels are measured each year and compared with levels from previous years to determine changes over time. Only water levels from municipal and stock wells that are not considered recently pumped, influenced by nearby pumping, or blocked or obstructed are used for comparison. During May and June 2004, water levels in 26 of the 34 wells that are used for observation met these criteria (table 5). Six of the 26 wells are continuous-recording observation wells, and water levels were measured manually in these wells six times between May 2003 and June 2004. Water levels in 23 of the 26 wells in 2004 were compared with water levels in 2003. Water levels in the remaining 3 wells could not be compared because of obstructions in the well, effects of pumping, or other conditions that prevented an accurate water level to be measured in 2003 and (or) 2004. Kitsillie NTUA 2 was added to the observation-well network this year because Forest Lake NTUA 1 has been obstructed for the last few years, leaving a gap in water-level data for the northern part of Black Mesa.

The wells used for water-level measurements are distributed throughout the study area (fig. 5). Although all the wells are completed in the $\mathrm{N}$ aquifer, characteristics of the wells vary considerably. Construction dates range from 1934 to 1999 , depths range from $107 \mathrm{ft}$ near Dennehotso to $3,535 \mathrm{ft}$ near PWCC, and depths to the top of the $\mathrm{N}$ aquifer range from 0 to $2,617 \mathrm{ft}$ (table 6 ).

From 2003 to 2004, water levels declined in 13 of the 23 wells for which comparisons could be made (table 5). The median water-level change in the 23 wells was $-0.2 \mathrm{ft}$ (table 7). From 2003 to 2004, water levels declined in 6 of the 12 wells in the unconfined parts of the aquifer. The median water-level change was $-0.1 \mathrm{ft}$. Water-level changes ranged from $-30.8 \mathrm{ft}$ at 9 Y-95 in Rough Rock to $+6.2 \mathrm{ft}$ at Tuba City NTUA 1. In the confined area, water levels declined in 7 of 11 wells from 2003 to 2004 . The median water-level change was $-2.7 \mathrm{ft}$. Water-level changes ranged from -14.6 ft at Keams Canyon PM 2 to $+4.0 \mathrm{ft}$ at Kykotsmovi PM 1 (tables 5 and 7).

Annual median water-level changes for the water-level network wells from 1983 to 2004 are shown in figure 6 . Annual median changes before 1983 are not shown because there were insufficient water-level data to compute median values. For wells in the confined area, the annual median water-level change was $-1.8 \mathrm{ft}$, and there was no appreciable trend in the annual water-level changes from 1983 to 2004. For wells in unconfined areas, the annual median water-level change was $+0.2 \mathrm{ft}$, and there is no appreciable trend from 1983 to 2004. 
Table 4. Flowmeter-test results for selected municipal wells that are completed in the N aquifer, Black Mesa area, Arizona, 2004

\begin{tabular}{|c|c|c|c|c|c|c|}
\hline \multirow[b]{2}{*}{ Well name } & \multirow[b]{2}{*}{$\begin{array}{l}\text { Date tested } \\
\text { or visited }\end{array}$} & \multicolumn{2}{|c|}{$\begin{array}{c}\text { Pumping rate } \\
\text { (gallons per minute) }\end{array}$} & \multirow[b]{2}{*}{$\begin{array}{c}\text { Percent } \\
\text { difference }^{2}\end{array}$} & \multirow{2}{*}{\multicolumn{2}{|c|}{$\begin{array}{l}\text { Name and number } \\
\text { of permanent meter }\end{array}$}} \\
\hline & & $\begin{array}{c}\text { Permanent } \\
\text { meter }\end{array}$ & Test meter ${ }^{1}$ & & & \\
\hline \multicolumn{7}{|c|}{ Navajo Tribal Utility Authority (NTUA) } \\
\hline Chilchinbito NTUA1 & 06-08-04 & 51 & 51 & -0.2 & Sensus & 62569678 \\
\hline Dennehotso NTUA 2 & 06-08-04 & 98 & 101 & -4.1 & Rockwell & 1306471 \\
\hline Forest Lake NTUA 1 & 06-09-04 & 41 & 46 & -10.9 & Hersey & 6049985 \\
\hline Hard Rock NTUA 1 & 06-10-04 & $\left({ }^{3}\right)$ & $\left({ }^{3}\right)$ & $\left({ }^{3}\right)$ & $\left({ }^{3}\right)$ & $\left({ }^{3}\right)$ \\
\hline Hard Rock NTUA 2 & 06-14-04 & 110 & 110 & -1.2 & Sensus & 1469178 \\
\hline Kayenta NTUA 3 & 06-08-04 & 140 & 133 & 4.0 & Sensus & 1385421 \\
\hline Kayenta NTUA 4 & 06-08-04 & 252 & 253 & -1.7 & Sensus & 24673169 \\
\hline Kayenta NTUA 5 & 06-08-04 & $\left({ }^{3}\right)$ & $\left({ }^{3}\right)$ & $\left({ }^{3}\right)$ & $\left({ }^{3}\right)$ & $\left({ }^{3}\right)$ \\
\hline Kayenta NTUA 6 & 06-08-04 & 140 & 153 & -9.2 & Sensus & 1412051 \\
\hline Kayenta NTUA 7 & 06-08-04 & $\left({ }^{3}\right)$ & $\left({ }^{3}\right)$ & $\left({ }^{3}\right)$ & $\left({ }^{3}\right)$ & $\left({ }^{3}\right)$ \\
\hline Kitsillie NTUA 1 & 06-10-04 & 29 & 30 & -2.8 & Sensus & 53189191 \\
\hline Kitsillie NTUA 2 & 06-10-04 & 72 & 74 & -3.8 & Sensus & 1451526 \\
\hline Piñon NTUA 1 & 06-09-04 & 100 & 101 & -1.9 & Sensus & 1442466 \\
\hline Shonto Junction NTUA 2 & 06-09-04 & 98 & 95 & 2.0 & Brooks & $9504 \mathrm{HC} 090486$ \\
\hline Shonto NTUA 1 & 06-09-04 & 54 & 57 & -5.6 & Rockwell & 28945149 \\
\hline Tuba City NTUA 1 & 06-02-04 & $\left({ }^{4}\right)$ & $\left({ }^{4}\right)$ & $\left({ }^{4}\right)$ & $\left({ }^{4}\right)$ & $\left({ }^{4}\right)$ \\
\hline Tuba City NTUA 2 & 06-02-04 & 183 & 173 & 4.9 & Sparling & 129709 \\
\hline Tuba City NTUA 3 & 06-02-04 & 159 & 161 & -2.6 & Sensus & 46571 \\
\hline Tuba City NTUA 4 & 06-02-04 & 177 & 188 & -7.0 & Sparling & 126447 \\
\hline Tuba City NTUA 5 & 06-02-04 & 199 & 204 & -3.6 & Sparling & 126189 \\
\hline Tuba City NTUA 6 & 06-02-04 & $\left({ }^{5}\right)$ & $\left({ }^{5}\right)$ & $\left({ }^{5}\right)$ & $\left({ }^{5}\right)$ & $\left({ }^{5}\right)$ \\
\hline
\end{tabular}

\footnotetext{
${ }^{1}$ Invensys $125-\mathrm{W}$ portable large meter tester (maximum flow rate of 300 gallons per minute).

${ }^{2}$ Percent difference $=((([$ average rate at the permanent meter] $/[$ average rate at the test meter] $) *$ accuracy coefficient] $)-100) / 100$. A positive difference indicates that the permanent meter is registering more pumpage than the test flowmeter, whereas a negative difference indicates that it is registering less.

${ }^{3}$ Well not in operation during quality-assurance visit.

${ }^{4}$ Well not tested because test meter could not be connected.

${ }^{5}$ Well not tested because pumpage exceeded the maximum flow rate of the test meter.
} 


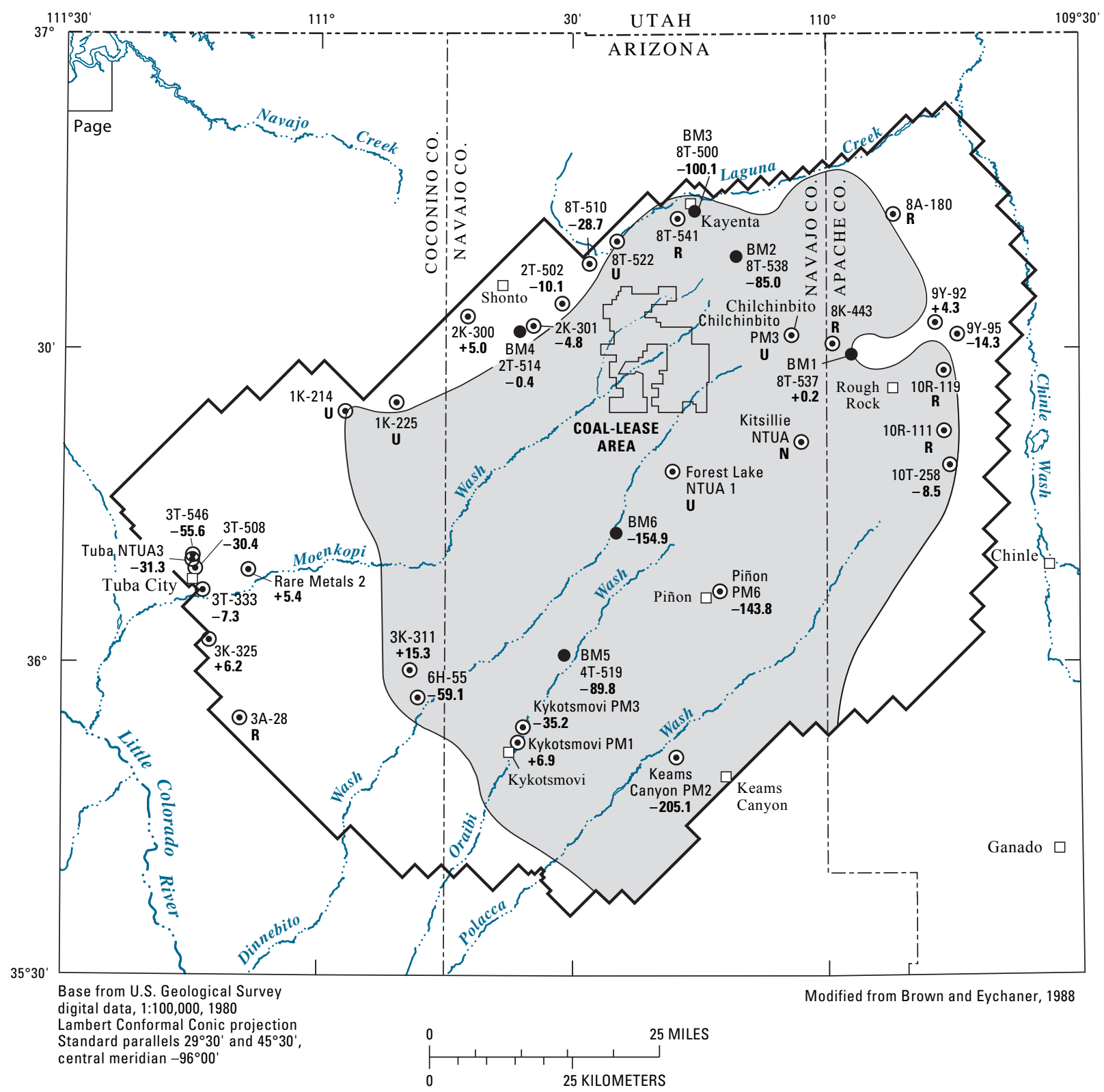

EXPLANATION

CONFINED AND UNCONFINED CONDITIONS IN THE N AQUIFER

Confined

Unconfined

APPROXIMATE BOUNDARY

BETWEEN CONFINED AND

UNCONFINED CONDITIONS -

From Brown and Eychaner (1988)

BOUNDARY OF MATHEMATICAL

MODEL-From Brown and

Eychaner (1988)
○ WELL IN WHICH DEPTH TO 2K-300 WATER WAS MEASURED
$\mathbf{+ 5 . 0}$ $2 \mathrm{~K}-300$, is Bureau of Indian Affairs site number; second entry, $+\mathbf{5 . 0}$, is change in

water level, in feet, between measurement made during the prestress period and measurement made during 2004. U, unable to measure. $\mathbf{R}$, recently pumping, and $\mathbf{N}$, new well
CONTINUOUS WATER-LEVEL RECORDING SITE (OBSERVATION WELL) MAINTAINED BY THE U.S. GEOLOGICAL SURVEY-First entry, BM2, is U.S. Geological Survey well number; second entry. 8T-538, is Bureau of Indian Affairs site number; third entry, -85.0, is change in water level, in feet, from simulated prestress period to 2004

Figure 5. Water-level changes in N aquifer wells from the prestress period to 2004, Black Mesa area, Arizona. 
Table 5. Water-level changes in wells completed in the $\mathrm{N}$ aquifer, Black Mesa area, Arizona, prestress period to 2004.

[Dashes indicate no data. Do., ditto; R, reported from driller's log]

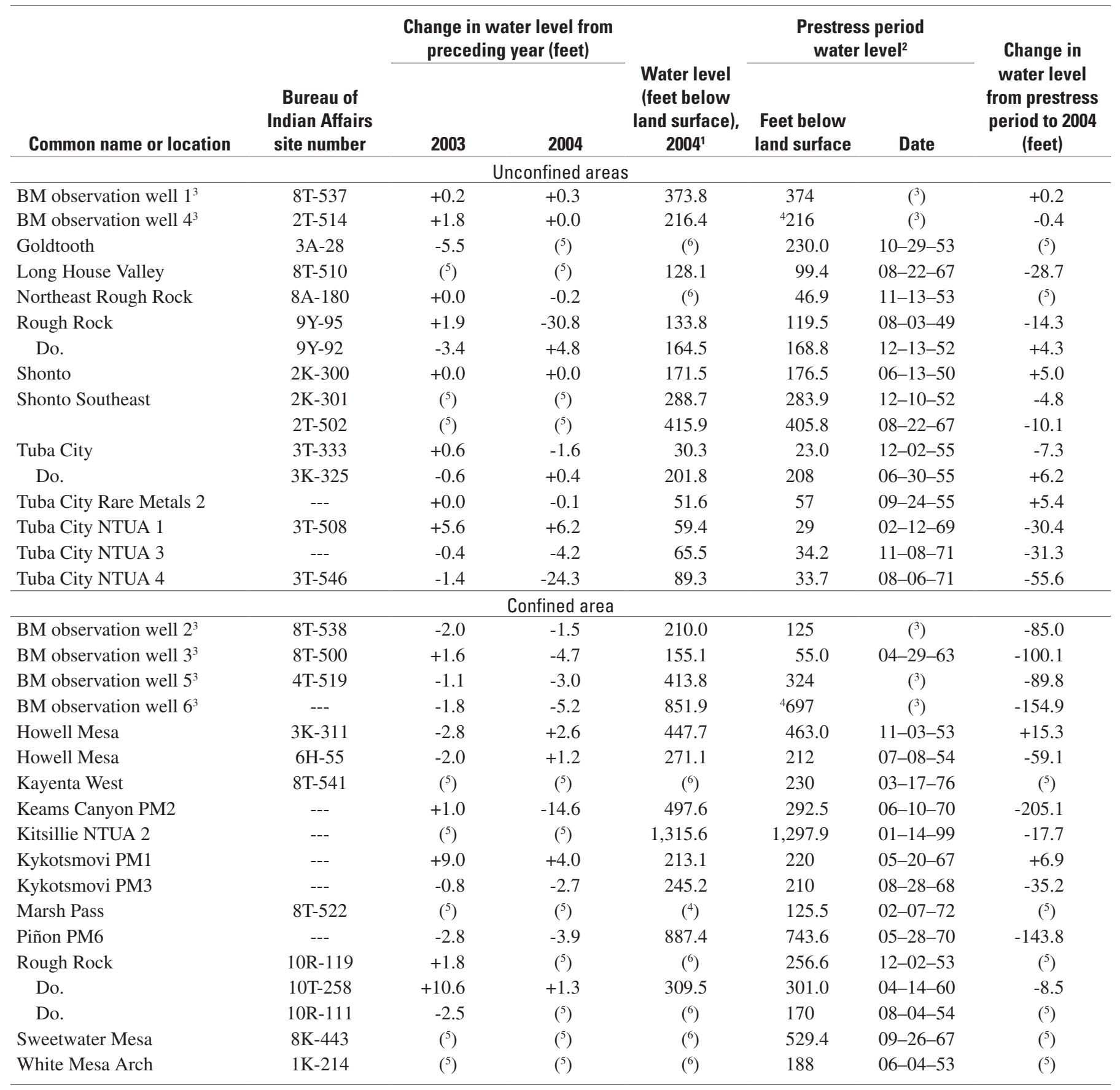

\footnotetext{
${ }^{1}$ Water level measured during May to June 2004.

${ }^{2}$ Prestress refers to the period of record before appreciable ground-water withdrawals for mining or municipal purposes-about 1965 . For wells that had no water-level measurement before 1965, the earliest water-level measurement is shown.

${ }^{3}$ Continuous recorder. Except for well BM3, prestress water levels were estimated from a ground-water model (Brown and Eychaner, 1988).

${ }^{4}$ Water level not measured because of obstruction in well, no access to well, or not visited.

${ }^{5} \mathrm{Can}$ not be determined because at least one of the water-level measurements is not available.

${ }^{6}$ Well recently pumped.
} 
Table 6. Well-construction characteristics, depth to top of $\mathrm{N}$ aquifer, and type of data collected for wells in the monitoring program, Black Mesa area, Arizona, 2003-04

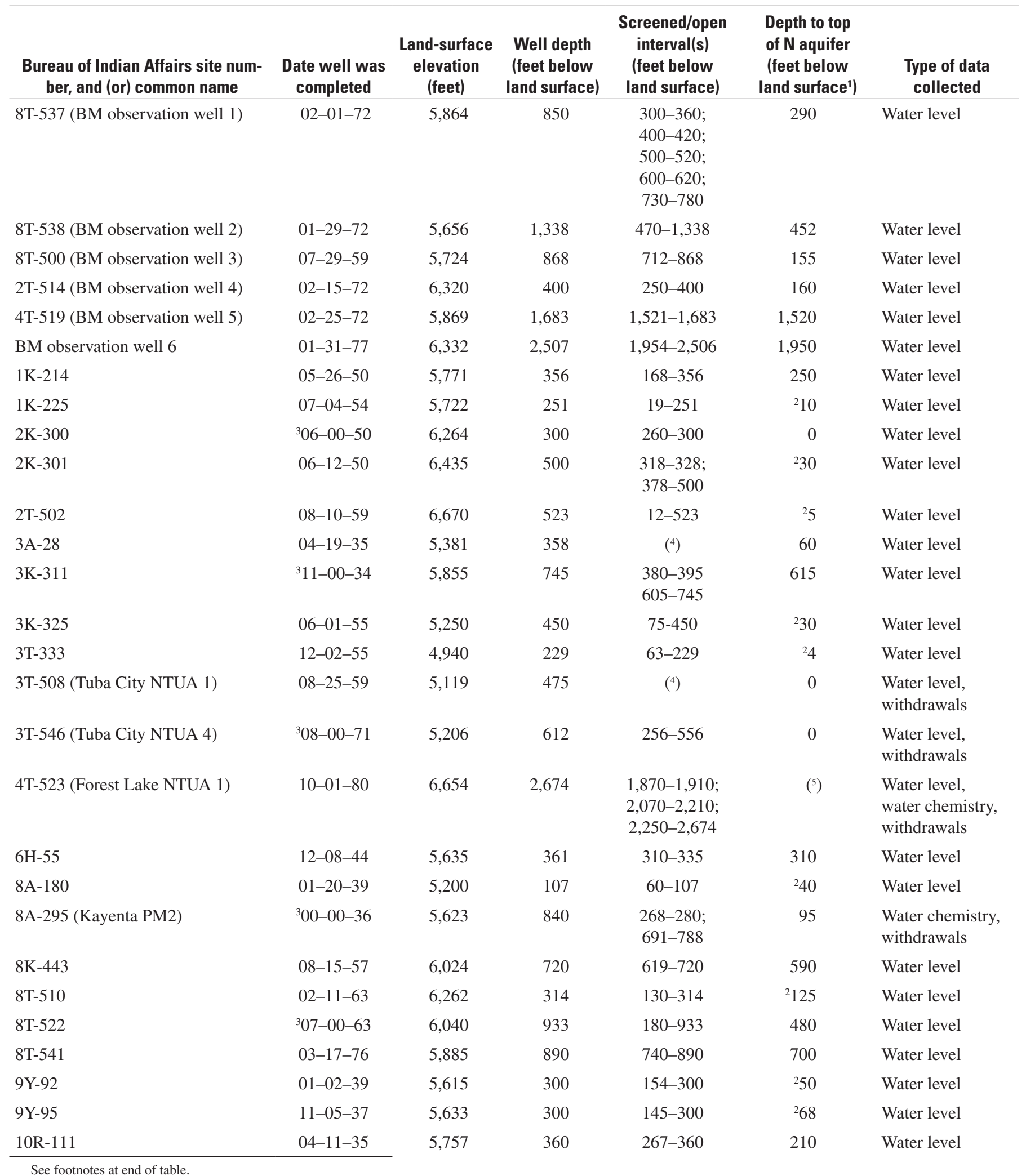


Table 6. Well-construction characteristics, depth to top of N aquifer, and type of data collected for wells in monitoring program, Black Mesa area, Arizona, 2003-04-Continued

\begin{tabular}{|c|c|c|c|c|c|c|}
\hline $\begin{array}{c}\text { Bureau of Indian Affairs site } \\
\text { number, and (or) common name }\end{array}$ & $\begin{array}{c}\text { Date well was } \\
\text { completed }\end{array}$ & $\begin{array}{c}\text { Land-surface } \\
\text { elevation } \\
\text { (feet) }\end{array}$ & $\begin{array}{l}\text { Well depth } \\
\text { (feet below } \\
\text { land surface) }\end{array}$ & $\begin{array}{c}\text { Screened/open } \\
\text { interval(s) } \\
\text { (feet below } \\
\text { land surface) }\end{array}$ & $\begin{array}{l}\text { Depth to top of } \\
\mathrm{N} \text { aquifer } \\
\text { (feet below } \\
\text { land surface') }\end{array}$ & $\begin{array}{l}\text { Type of data } \\
\text { collected }\end{array}$ \\
\hline 10R-119 & $01-09-35$ & 5,775 & 360 & (4) & 310 & Water level \\
\hline $10 \mathrm{~T}-258$ & $04-12-60$ & 5,903 & 670 & $465-670$ & 460 & Water level \\
\hline Keams Canyon PM2 & ${ }^{3} 05-00-70$ & 5,809 & 1,106 & $906-1,106$ & 900 & $\begin{array}{l}\text { Water level, } \\
\text { withdrawals }\end{array}$ \\
\hline Keams Canyon PM3 & ${ }^{3} 01-00-76$ & 5,806 & 1,090 & $931-1,090$ & 930 & Water chemistry \\
\hline Kykotsmovi PM1 & $02-20-67$ & 5,657 & 995 & $\begin{array}{l}655-675 \\
890-990\end{array}$ & 880 & $\begin{array}{l}\text { Water level, } \\
\text { withdrawals }\end{array}$ \\
\hline Kykotsmovi PM2 & $10-14-77$ & 5,717 & 1,160 & $950-1,160$ & 890 & $\begin{array}{l}\text { Water chemistry, } \\
\text { withdrawals }\end{array}$ \\
\hline Kykotsmovi PM3 & $08-07-68$ & 5,618 & 1,220 & $850-1,220$ & 840 & $\begin{array}{l}\text { Water level, } \\
\text { withdrawals }\end{array}$ \\
\hline Low Mountain PM2 & ${ }^{3} 04-00-72$ & 6,123 & 1,343 & $1,181-1,262$ & 1,153 & Water level \\
\hline Peabody 4 & ${ }^{3} 05-00-68$ & 6,229 & 3,535 & $2,029-3,458$ & 2,280 & $\begin{array}{l}\text { Water chemistry, } \\
\text { withdrawals }\end{array}$ \\
\hline Rocky Ridge PM2 & $06-26-63$ & 5,985 & 1,780 & $1,480-1,780$ & 1,442 & Water level \\
\hline Rough Rock PM5 & $06-27-64$ & 6,299 & 1,420 & $1,180-1,420$ & 1,156 & $\begin{array}{l}\text { Water chemistry, } \\
\text { withdrawals }\end{array}$ \\
\hline Second Mesa PM2 & ${ }^{3} 10-00-68$ & 5,777 & 1,090 & $740-1,090$ & 720 & $\begin{array}{l}\text { Water chemistry, } \\
\text { withdrawals }\end{array}$ \\
\hline Shonto PM2 & $05-05-61$ & 6,465 & 554 & $485-510$ & 0 & Water chemistry \\
\hline Tuba City NTUA 3 & ${ }^{3} 10-00-71$ & 5,176 & 442 & $142-442$ & 34 & $\begin{array}{l}\text { Water level, } \\
\text { withdrawals }\end{array}$ \\
\hline Tuba City Rare Metals 2 & ${ }^{3} 09-00-55$ & 5,108 & 705 & $100-705$ & 255 & Water level \\
\hline
\end{tabular}

${ }^{1}$ Depth to top of $\mathrm{N}$ aquifer from Eychaner (1983) and Brown and Eychaner (1988).

${ }^{2}$ All material between land surface and top of the $\mathrm{N}$ aquifer is unconsolidated—soil, alluvium, or dune sand.

${ }^{3} 00$, indicates month or day is unknown.

${ }^{4}$ Screened and (or) open intervals are unknown.

${ }^{5}$ Depth to top of $\mathrm{N}$ aquifer was not estimated. 
Table 7. Median changes in water levels, 2003-04 and prestress period to 2004, Black Mesa area, Arizona

\begin{tabular}{clcc}
\hline & Aquifer conditions & Number of wells & $\begin{array}{c}\text { Median change in } \\
\text { water level (feet) }\end{array}$ \\
\hline $2003-04$ & All & 23 & -0.2 \\
& Unconfined & 12 & -0.1 \\
& Confined & 11 & -2.7 \\
Prestress-2004 & All & 26 & -23.2 \\
& Unconfined & 14 & -6.1 \\
& Confined & 12 & -72.1 \\
\hline
\end{tabular}

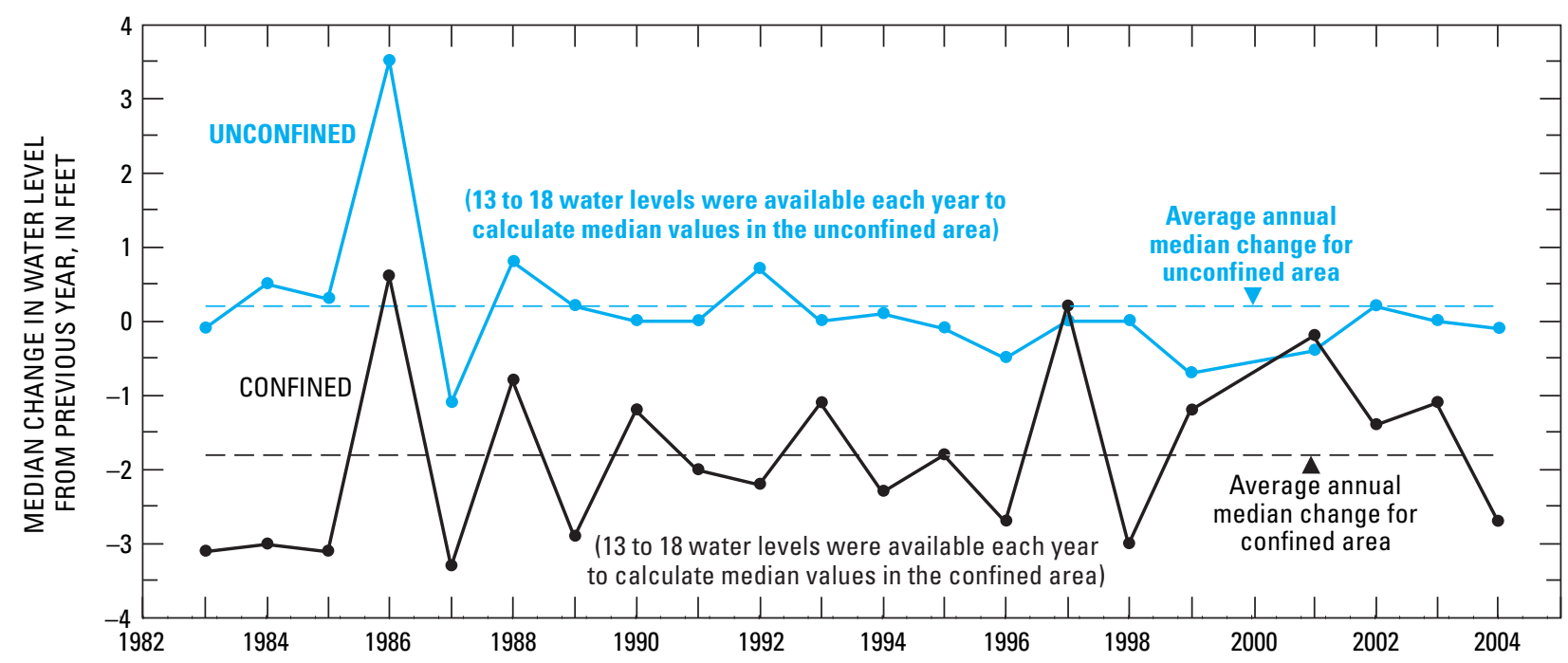

Figure 6. Annual median water-level changes for observation wells completed in the $\mathrm{N}$ aquifer, Black Mesa area, Arizona, 1983-2004. 
From the prestress period (prior to 1965) to 2004, the median water-level change in 26 wells was $-23.2 \mathrm{ft}$ (table 7). Water levels in 14 unconfined wells had a median change of $-6.1 \mathrm{ft}$. Water-level changes ranged from $-55.6 \mathrm{ft}$ at Tuba City NTUA 4 to $+6.2 \mathrm{ft}$ at $3 \mathrm{~K}-325$, which also is in Tuba City. Water levels in 12 confined wells had a median change of $-72.1 \mathrm{ft}$. Water-level changes ranged from -205.1 ft at Keams Canyon PM2 to $+15.3 \mathrm{ft}$ at 3K-311 (fig. 5 and tables 5 and 7).

The areal distribution of water-level changes from the prestress period to 2004 is shown in figure 5. Hydrographs of water levels in the annual observation-well network show the time trends of changes since the 1950s, 1960s, or 1970s (fig. 7). In most of the unconfined areas, water levels have changed only slightly. In the Tuba City area, however, water levels in three wells have declined about 30 to $56 \mathrm{ft}$ (fig. 5). Water levels have declined in most of the confined area; however, the magnitudes of declines are variable. Larger declines have occurred near the municipal pumping centers (wells Piñon PM6, Keams Canyon PM2, BM3) or near PWCC wells (BM6). Smaller declines have occurred away from the pumping centers (well 10T-258; fig. 5).

Hydrographs for the Black Mesa observation wells show continuous water-level changes since about 1963 (fig. 8). Water levels in the two wells in the unconfined areas (BM1 and BM4) have had small seasonal or year-to-year variation and have had small long-term changes since 1972. Water levels in wells in the confined area, except BM3, also have had little seasonal variation; however, the water levels have consistently declined in all these wells since the early to mid-1960s (fig. 8).

\section{Spring Discharge from the $\mathbf{N}$ Aquifer}

Ground water in the $\mathrm{N}$ aquifer discharges from many springs around the margins of Black Mesa, and four of these springs are monitored for discharge. Three springs are in the western or southwestern part of the Black Mesa area, and one is in the northeastern part (fig.9). Discharges from Moenkopi School Spring, the unnamed spring near Dennehotso, Pasture Canyon Spring, and Burro Spring are measured annually and compared to discharges from previous years to determine changes over time (fig. 10). Discharge was measured in March-April 2004 at the four springs (table 8). Measurements have been made from the same location at each of the spring sites. Measurements at Burro Spring, Moenkopi School Spring, and Pasture Canyon Spring are made volumetrically, and measurements at the unnamed spring near Dennehotso are made with a flume. The measurements may not reflect the total discharge at each site because some ground water may rise to the land surface downgradient from the measuring point.

In 2004, measured discharges were $0.2 \mathrm{gal} / \mathrm{min}$ from Burro Spring, $12.2 \mathrm{gal} / \mathrm{min}$ from Moenkopi School Spring, $12.6 \mathrm{gal} / \mathrm{min}$ from the unnamed spring near Dennehotso, and $30.6 \mathrm{gal} / \mathrm{min}$ from Pasture Canyon Spring. From 2003 to 2004 , discharge decreased by 50 percent at Burro Spring, increased by 9 percent for Moenkopi School Spring, decreased by 26 percent for the unnamed spring near Dennehotso, and stayed about the same for Pasture Canyon Spring. For the consistent periods of record at all four springs, the discharges have fluctuated but long-term trends are not apparent (fig. 10).

\section{Surface-Water Discharge}

Surface-water discharge in the study area includes ground-water discharge to streams and direct or shallow subsurface runoff of rainfall or snowmelt. Ground water discharges to some channel reaches at a fairly constant rate throughout the year; however, the amount of discharge that results in surface flow is affected by seasonal fluctuations in water uptake by plants and in evapotranspiration (Thomas, 2002a). In contrast, the amount of rainfall or snowmelt runoff varies widely throughout the year. In the winter and spring, the amount and timing of snowmelt runoff is a result of the temporal variation in snow accumulation, air temperatures, and rate of snowmelt. Although most rainfall runoff is in the summer, rainfall can result in surface-water runoff throughout the year. The amount and timing of rainfall runoff depend on the intensity and duration of thunderstorms in the summer and cyclonic storms in the fall, winter, and spring.

Continuous surface-water discharge data have been collected at selected streams each year since the monitoring program began in 1971 to provide information about groundwater discharge and runoff from rainfall and snowmelt. In this study, the total discharge in streams is roughly separated into ground-water discharge and runoff so that the temporal trends in ground-water discharge can be monitored.

In 2003, continuous discharge data were collected at four streamflow-gaging stations (tables 9-12). Data collection at these stations began in July 1976 (Moenkopi Wash), July 1996 (Laguna Creek), June 1993 (Dinnebito Wash), and April 1994 (Polacca Wash; fig. 9 and table 13). In August of 2004, a continuous-recording gage was installed at Pasture Canyon Spring downstream from the discharge-measuring point for the spring. The annual average discharges at the four gaging stations vary considerably during their periods of record (fig. $11 B$ ), and no long-term trends are apparent.

The ground-water discharge component of total flow at the four streamflow-gaging stations was estimated by computing the median flow for four winter monthsNovember, December, January, and February (fig. 11C). The 120 consecutive daily mean flows for those four months were used to compute the median flow. Ground-water discharge is assumed to be constant throughout the entire year, and the median winter flow is assumed to represent this constant annual ground-water discharge. Most flow during the winter is ground-water discharge; rainfall and snowmelt runoff are minimal. Most of the precipitation in the winter falls as snow, and the cold temperatures prevent appreciable snowmelt. 
UNCONFINED AREA

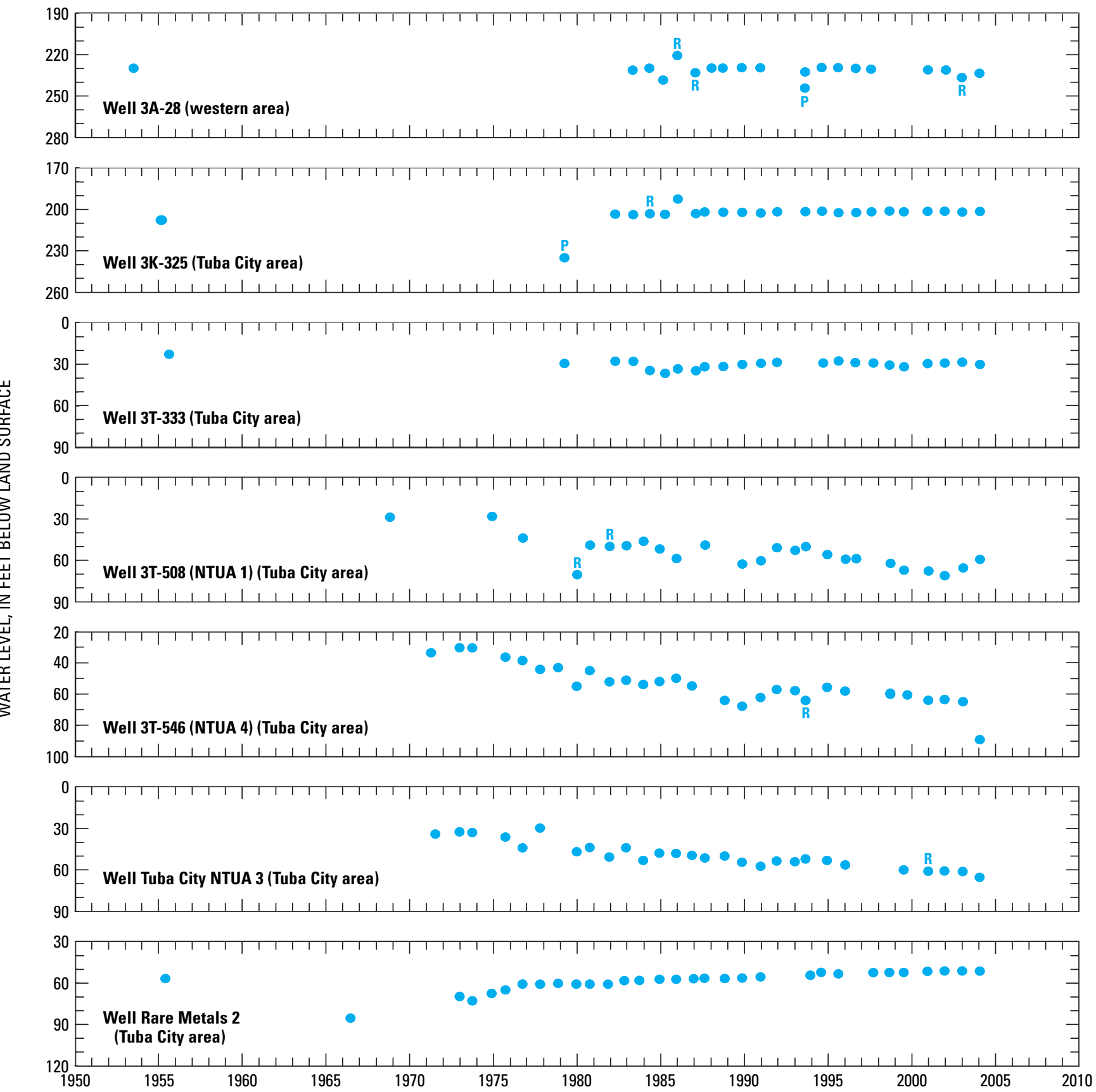

Figure 7. Observed water levels (1950-2004) in annual observation-well network, Black Mesa area, Arizona.

$P$, pumping, $R$, recently pumping. 
UNCONFINED AREA
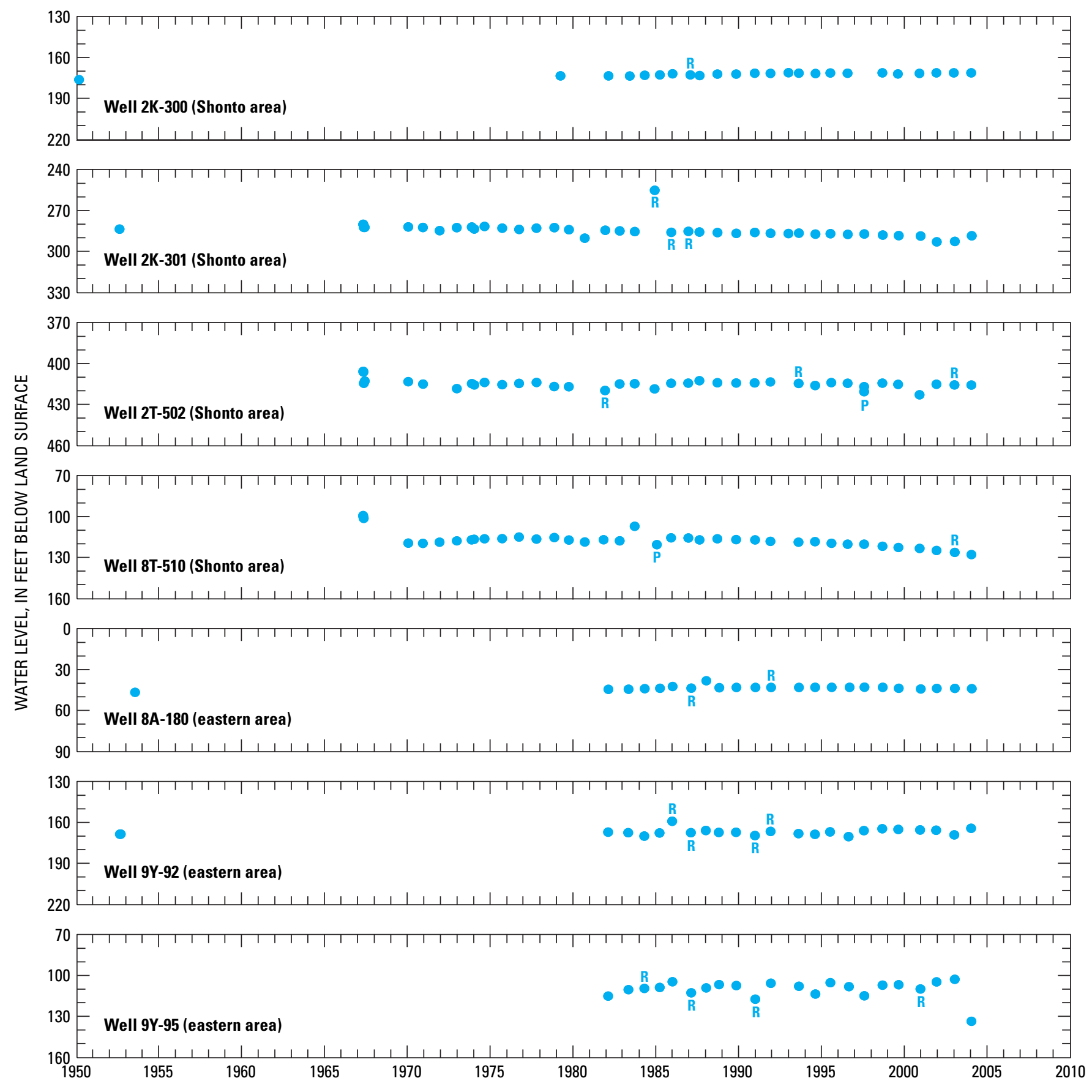

Figure 7. Continued. 
CONFINED AREA
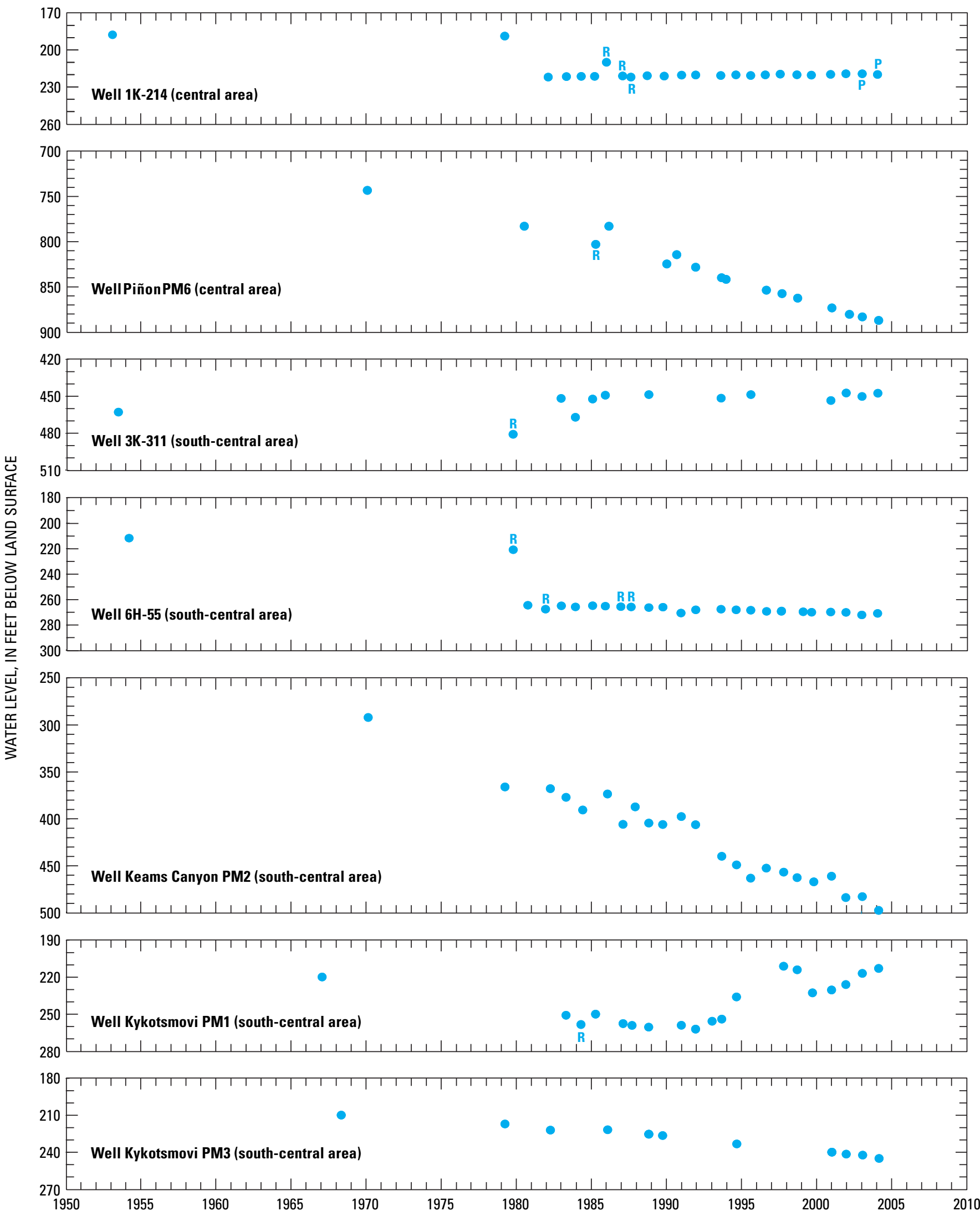

Figure 7. Continued. 
CONFINED AREA
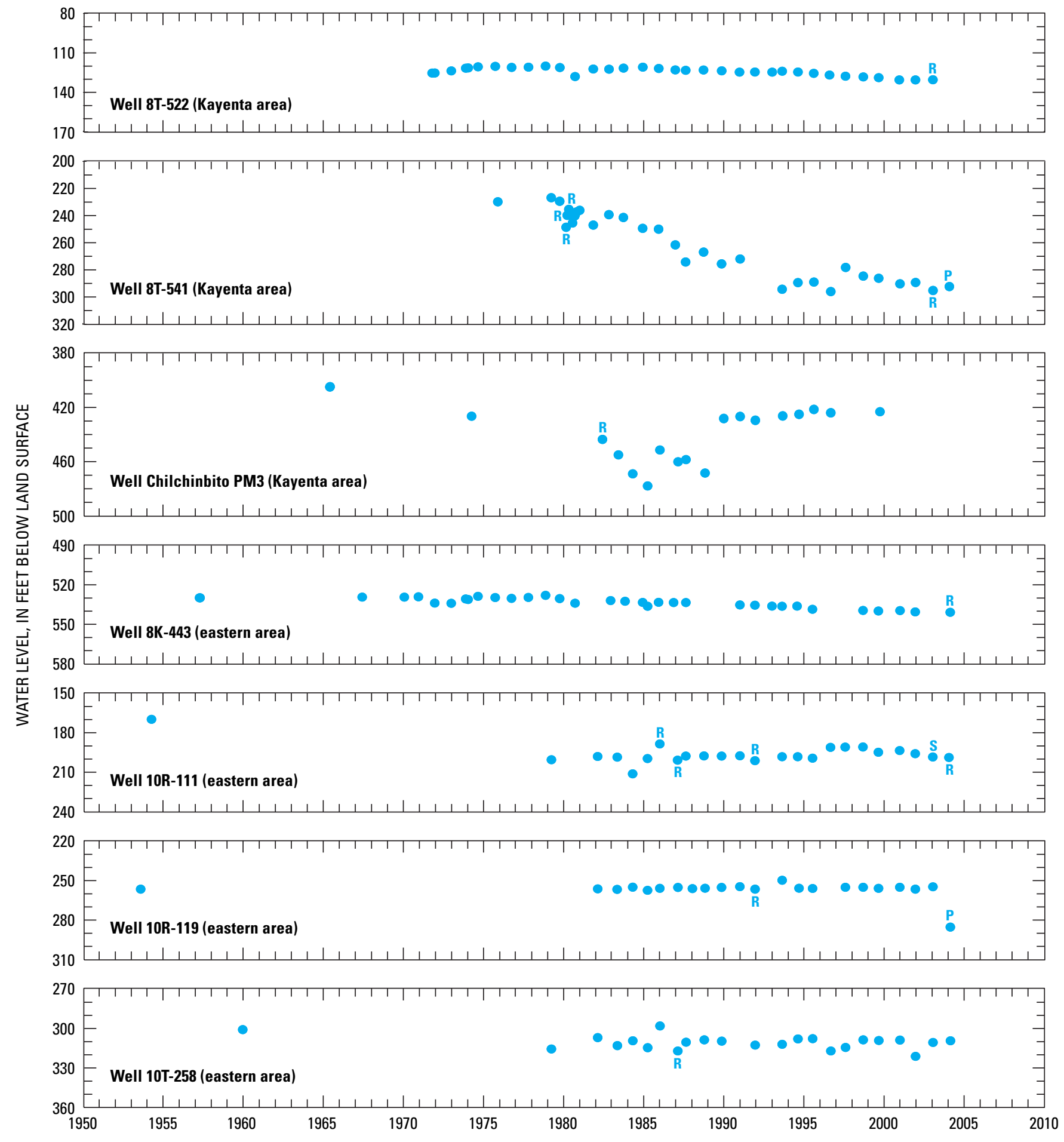

Figure 7. Continued. 


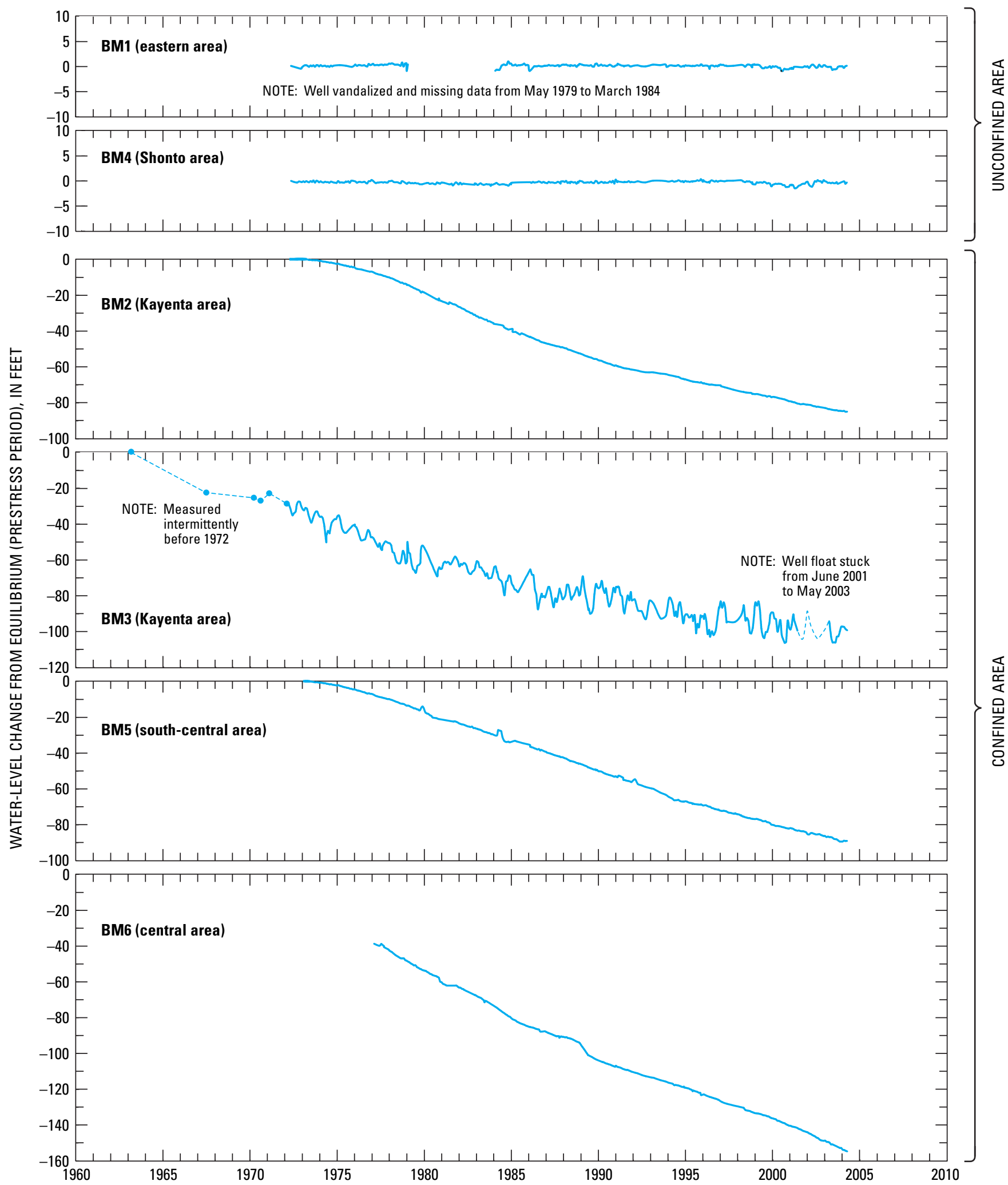

Figure 8. Observed water-level changes in continuous-record observation wells, BM1-BM6, Black Mesa area, Arizona. 


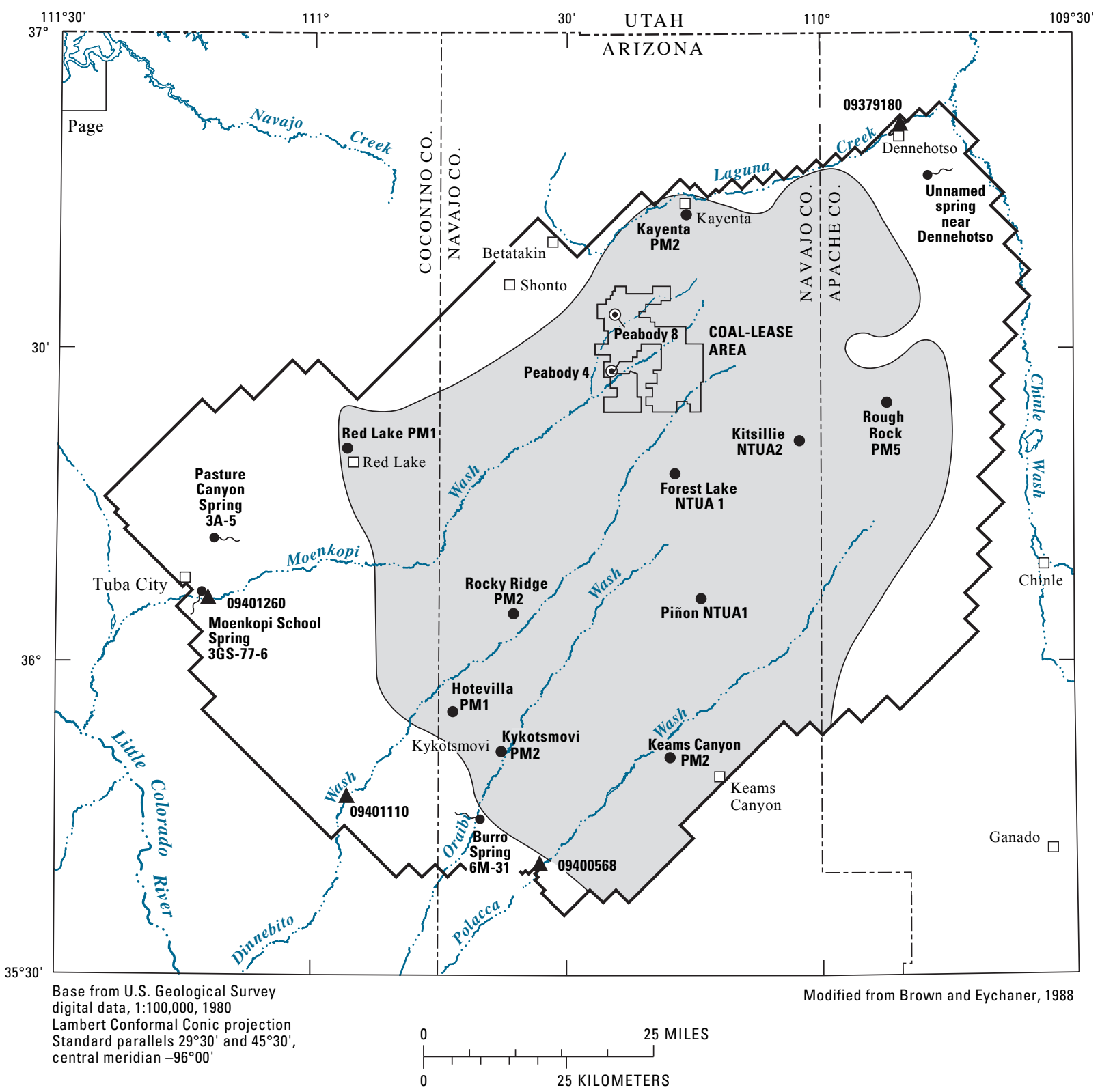

EXPLANATION

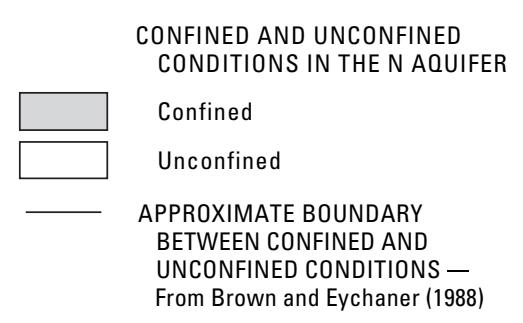

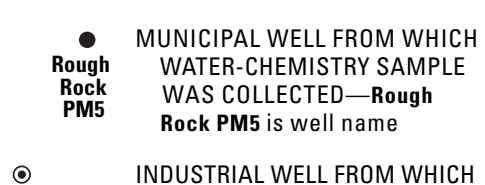

Peabody 8 WATER-CHEMISTRY SAMPLE

WAS COLLECTED-Peabody 8

is well number

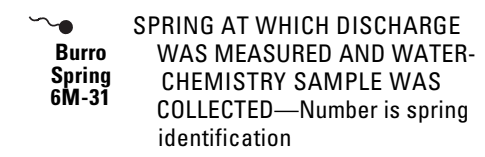

- StreamfloW-gaging Station

09401260 OPERATED BY THE U.S. GEOLOGICAL SURVEY-Number is station identification

Figure 9. Surface-water and water-chemistry data-collection sites, Black Mesa area, Arizona, 2003-04. 


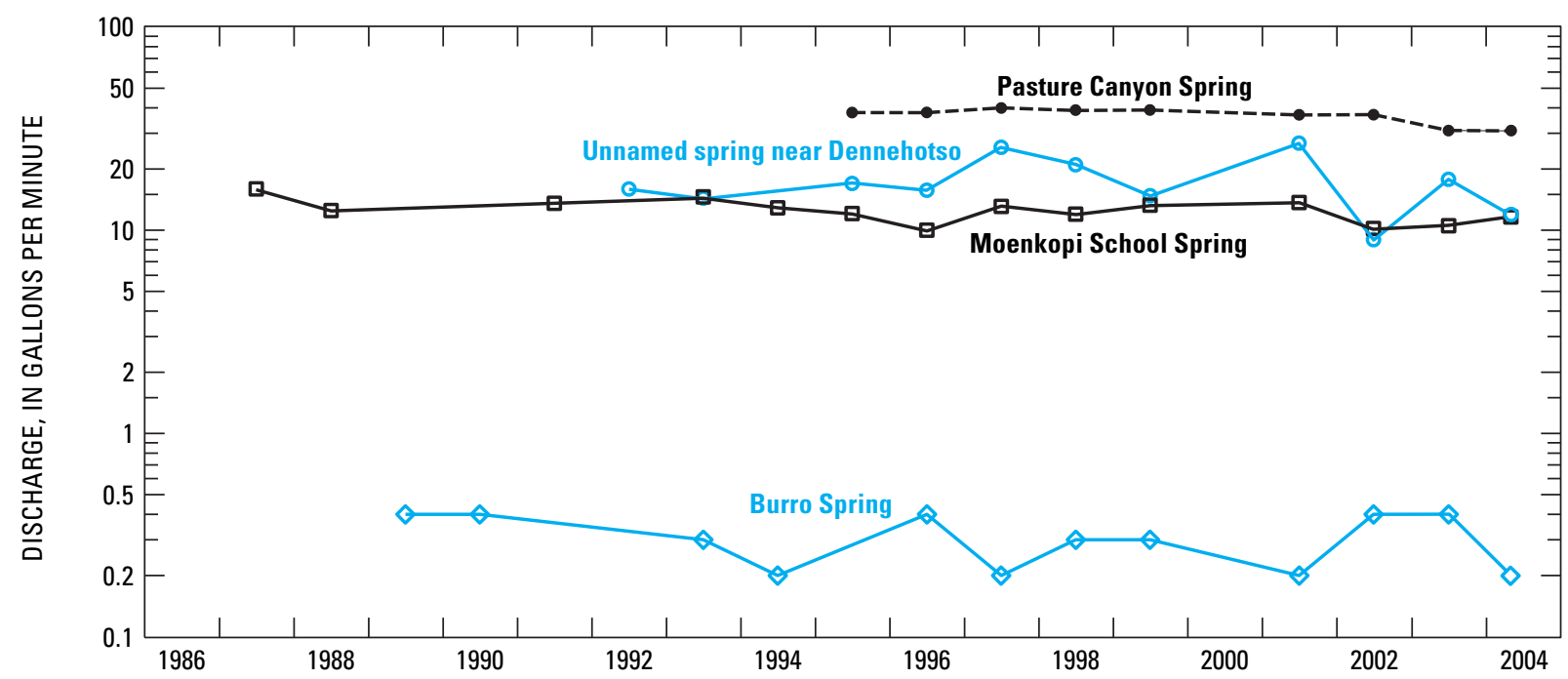

Figure 10. Discharge from selected springs, Black Mesa area, Arizona, 1987-2004. Data from earlier measurements at Moenkopi School Spring, the unnamed spring near Dennehotso, and Pasture Canyon Spring are not shown because different measuring locations were used. 
Table 8. Discharge measurements of selected springs, Black Mesa area, Arizona, 1952-2004

[All the measured discharges do not represent the total discharge from the springs]

\begin{tabular}{|c|c|c|c|c|c|c|c|}
\hline $\begin{array}{l}\text { Bureau of } \\
\text { Indian Affairs } \\
\text { site number }\end{array}$ & Rock formation(s) & $\begin{array}{c}\text { Date of } \\
\text { measurement }\end{array}$ & $\begin{array}{c}\text { Discharge } \\
\text { (gallons per } \\
\text { minute) }\end{array}$ & $\begin{array}{c}\text { Bureau of } \\
\text { Indian Affairs } \\
\text { site number }\end{array}$ & Rock formation(s) & $\begin{array}{c}\text { Date of } \\
\text { measurement }\end{array}$ & $\begin{array}{c}\text { Discharge } \\
\text { (gallons per } \\
\text { minute) }\end{array}$ \\
\hline \multicolumn{4}{|c|}{ Moenkopi School Spring ${ }^{1}$} & \multicolumn{4}{|c|}{ Pasture Canyon Spring $^{1}$} \\
\hline \multirow[t]{15}{*}{$3 \mathrm{GS}-77-6$} & \multirow[t]{15}{*}{ Navajo Sandstone $^{2}$} & $05-16-52$ & 40 & \multirow[t]{12}{*}{$3 \mathrm{~A}-5$} & \multirow[t]{12}{*}{$\begin{array}{l}\text { Navajo Sandstone, } \\
\text { alluvium }\end{array}$} & $11-18-88$ & ${ }^{6} 211$ \\
\hline & & $04-22-87$ & ${ }^{3} 16$ & & & 03-24-92 & ${ }^{6} 233$ \\
\hline & & $11-29-88$ & ${ }^{3} 12.5$ & & & $10-12-93$ & ${ }^{6} 211$ \\
\hline & & $02-21-91$ & ${ }^{3} 13.5$ & & & $12-04-95$ & 738 \\
\hline & & 04-07-93 & ${ }^{3} 14.6$ & & & $12-16-96$ & ${ }^{7} 38$ \\
\hline & & $12-07-94$ & ${ }^{3} 12.9$ & & & $12-17-97$ & ${ }^{7} 40$ \\
\hline & & $12-04-95$ & ${ }^{3} 12.1$ & & & $12-10-98$ & ${ }^{7} 39$ \\
\hline & & $12-16-96$ & ${ }^{3} 10$ & & & $12-21-99$ & 739.0 \\
\hline & & $12-17-97$ & ${ }^{3} 13.1$ & & & $06-12-01$ & ${ }^{7} 37.0$ \\
\hline & & $12-08-98$ & ${ }^{3} 12.0$ & & & $06-19-02$ & 737.0 \\
\hline & & $12-13-99$ & ${ }^{3} 13.3$ & & & $05-01-03$ & 730.9 \\
\hline & & $03-12-01$ & ${ }^{3} 13.7$ & & & $04-26-04$ & ${ }^{7} 30.6$ \\
\hline & & $06-19-02$ & ${ }^{3} 10.2$ & \multicolumn{4}{|c|}{ Burro Spring ${ }^{1}$} \\
\hline & & $05-01-03$ & ${ }^{3} 11.2$ & \multirow[t]{17}{*}{$6 \mathrm{M}-31$} & \multirow[t]{17}{*}{ Navajo Sandstone } & $12-15-89$ & 0.4 \\
\hline & & 03-29-04 & ${ }^{3} 12.2$ & & & $12-13-90$ & .4 \\
\hline & \multicolumn{3}{|c|}{ Unnamed spring near Dennehotso ${ }^{4}$} & & & 03-18-93 & .3 \\
\hline \multirow[t]{14}{*}{$8 \mathrm{~A}-224$} & Navajo Sandstone & $10-06-54$ & ${ }^{5} 1$ & & & $12-08-94$ & .2 \\
\hline & & $06-27-84$ & ${ }^{5} 2$ & & & $12-17-96$ & .4 \\
\hline & & $11-17-87$ & ${ }^{5} 5$ & & & $12-30-97$ & .2 \\
\hline & & 03-26-92 & 16 & & & $12-08-98$ & .3 \\
\hline & & $10-22-93$ & 14.4 & & & $12-07-99$ & .3 \\
\hline & & $12-05-95$ & 17 & & & $04-02-01$ & .2 \\
\hline & & $12-19-96$ & 15.7 & & & 04-04-02 & .4 \\
\hline & & $12-31-97$ & 25.6 & & & 04-30-03 & .4 \\
\hline & & $12-14-98$ & 21.0 & & & 04-06-04 & ${ }^{8} .2$ \\
\hline & & $12-15-99$ & 14.8 & & & & \\
\hline & & $03-14-01$ & 26.8 & & & & \\
\hline & & $07-15-02$ & 9.0 & & & & \\
\hline & & $05-01-03$ & 17.1 & & & & \\
\hline & & 04-01-04 & 12.6 & & & & \\
\hline
\end{tabular}

${ }^{1}$ Volumetric discharge measurement.

${ }^{2}$ Tongue in the Kayenta Formation.

${ }^{3}$ Discharge measured at water-quality sampling site and at a different point than the measurement in 1952.

${ }^{4}$ Flume discharge measurement.

${ }^{5}$ Discharge measured at a different point than later measurements.

${ }^{6}$ Discharge measured in an irrigation ditch about 0.25 mile below water-quality sampling point.

${ }^{7}$ Discharge measured at water-quality sampling point about 20 feet below upper spring on west side of canyon.

${ }^{8}$ Discharge is approximate because the container used for the volumetric measurement was not calibrated. 
Table 9. Discharge data, Moenkopi Wash at Moenkopi, Arizona (09401260), calendar year 2003 [e, estimated. Dashes indicate no data]

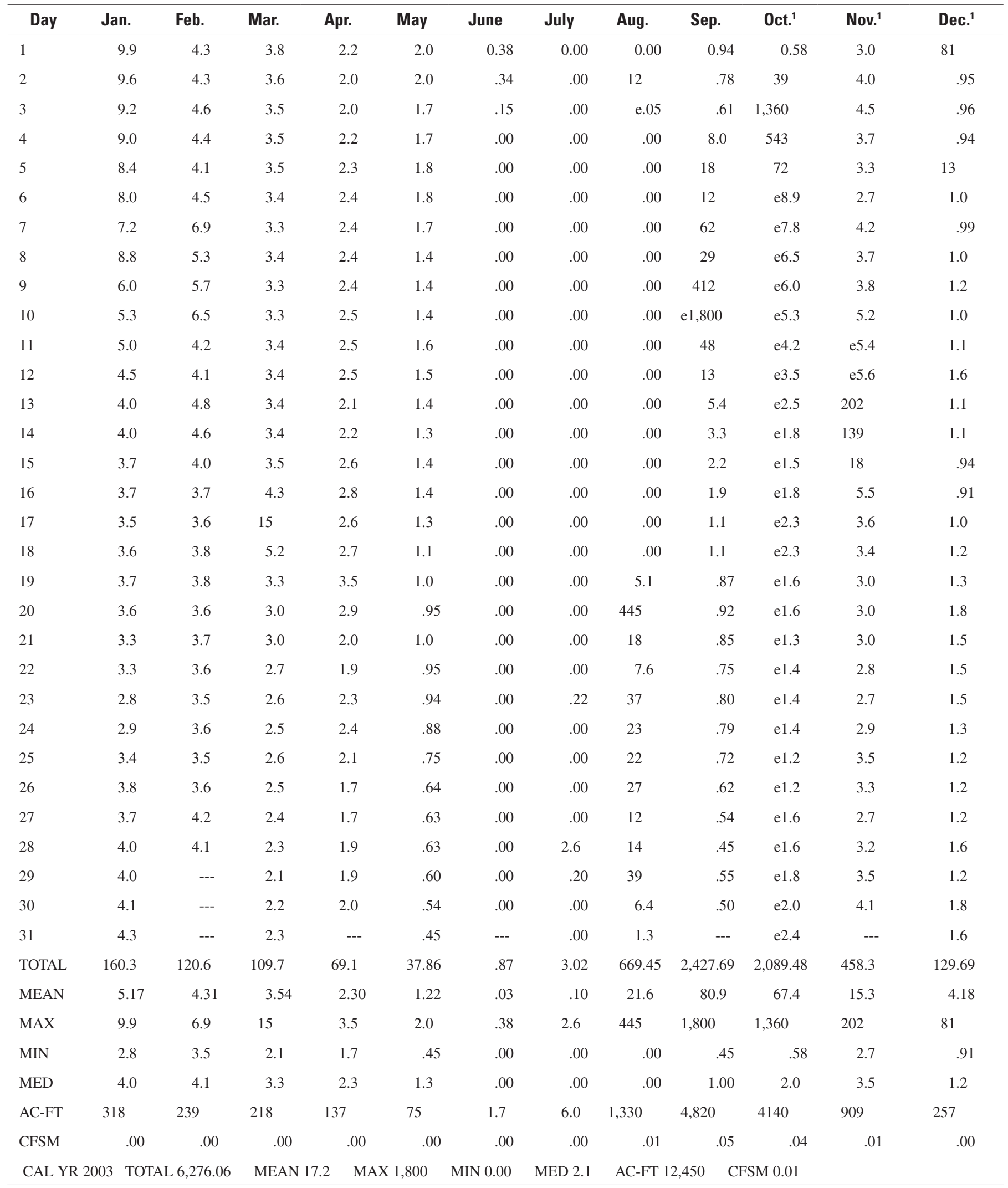


Table 10. Discharge data, Laguna Creek at Dennehotso, Arizona (09379180), calendar year 2003

[e, estimated. Dashes indicate no data]

\begin{tabular}{|c|c|c|c|c|c|c|c|c|c|c|c|c|}
\hline Day & Jan. & Feb. & Mar. & Apr. & May & June & July & Aug. & Sep. & Oct. ${ }^{1}$ & Nov. $^{1}$ & Dec. $^{1}$ \\
\hline 1 & 0.00 & $\mathrm{e} 0.80$ & 1.0 & 0.00 & 0.00 & 0.00 & 0.00 & e5.0 & 0.37 & 0.00 & 0.00 & 0.14 \\
\hline 2 & .00 & e. 50 & 1.3 & .00 & .00 & .00 & .00 & e30 & .08 & .00 & .00 & .17 \\
\hline 4 & e. 20 & e.04 & 1.2 & .00 & .00 & .00 & .00 & e20 & .02 & e92 & .00 & 1.5 \\
\hline 5 & e. 15 & .01 & 1.0 & .00 & .00 & .00 & .00 & 3.9 & 30 & e25 & .00 & 1.7 \\
\hline 7 & $\mathrm{e} 2.0$ & .00 & .60 & .00 & .00 & .00 & .00 & e.00 & e45 & $\mathrm{e} 2.3$ & .00 & 1.8 \\
\hline 8 & e1.0 & .00 & 1.3 & .00 & .00 & .00 & .00 & .00 & e. 10 & .51 & .00 & 2.8 \\
\hline 9 & e 3.0 & .00 & .58 & .00 & .00 & .00 & .00 & .45 & e70 & .05 & .00 & 1.0 \\
\hline 10 & e 4.0 & .00 & .33 & .00 & .00 & .00 & .00 & .67 & 518 & .00 & .00 & .43 \\
\hline 14 & $\mathrm{e} 1.3$ & $\mathrm{e} 1.3$ & .00 & .00 & .00 & .00 & .00 & .00 & .00 & .00 & 25 & .22 \\
\hline 15 & e5.6 & e5.6 & .00 & .00 & .00 & .00 & .00 & .00 & .00 & .00 & 7.9 & .25 \\
\hline 16 & e3.7 & e3.7 & .00 & .00 & .00 & .00 & .00 & .12 & .00 & .00 & 3.2 & .01 \\
\hline 17 & e1.7 & e1.8 & .41 & .00 & .00 & .00 & .00 & .91 & .00 & .00 & 1.8 & .00 \\
\hline 18 & e. 63 & e.63 & e14 & .00 & .00 & .00 & .00 & e.05 & .00 & .00 & 1.3 & .00 \\
\hline 19 & e. 14 & e. 14 & 14 & .00 & .00 & .00 & .00 & .00 & .00 & .00 & 1.1 & .00 \\
\hline 20 & e. 50 & e1.0 & e14 & .00 & .00 & .00 & .00 & .00 & .00 & .00 & 1.0 & .00 \\
\hline 21 & e1.0 & e. 50 & e5.0 & .00 & .00 & .00 & .00 & .00 & .00 & .00 & .80 & .00 \\
\hline 28 & e. 80 & .60 & .05 & .00 & .00 & .00 & .00 & .43 & .00 & .00 & .00 & .74 \\
\hline 29 & e1.0 & --- & .00 & .00 & .00 & .00 & e 32 & .08 & .00 & .00 & .00 & e. 90 \\
\hline 30 & e1.1 & --- & e1.0 & .00 & .00 & .00 & e8.0 & .02 & .00 & .00 & .18 & .56 \\
\hline 31 & $\mathrm{e} 1.0$ & --- & e.05 & --- & .00 & --- & e15 & e.00 & --- & .00 & --- & .74 \\
\hline TOTAL & 56.52 & 18.64 & 69.63 & .00 & .00 & .00 & 55.00 & 99.31 & 707.41 & 534.86 & 198.66 & 22.68 \\
\hline MEAN & 1.82 & .67 & 2.25 & .00 & .00 & .00 & 1.77 & 3.20 & 23.6 & 17.3 & 6.62 & .73 \\
\hline MAX & 10 & 5.6 & 14 & .00 & .00 & .00 & 32 & 32 & 518 & 405 & 155 & 3.1 \\
\hline MIN & .00 & .00 & .00 & .00 & .00 & .00 & .00 & .00 & .00 & .00 & .00 & .00 \\
\hline MED & 1.0 & .26 & 1.0 & .00 & .00 & .00 & .00 & .12 & .00 & .00 & .03 & .22 \\
\hline AC-FT & 112 & 37 & 138 & .00 & .00 & .00 & 109 & 197 & 1,400 & 1,060 & 394 & 45 \\
\hline & .00 & .00 & .01 & .00 & .00 & .00 & .00 & .01 & .06 & .04 & .02 & .00 \\
\hline \multicolumn{2}{|c|}{ CAL YR 2003} & L $1,762.71$ & MEAN 4.83 & $\mathrm{M}$ & 518 & $\mathrm{~N} 0.00 \quad \mathrm{I}$ & D 0.00 & AC-FT 3,500 & \multicolumn{2}{|c|}{ CFSM 0.01} & & \\
\hline
\end{tabular}

${ }^{1}$ Month in which data are provisional, subject to revision. 
Table 11. Discharge data, Dinnebito Wash near Sand Springs, Arizona (09401110), calendar year 2003

[Dashes indicate no data. e, estimated]

\begin{tabular}{|c|c|c|c|c|c|c|c|c|c|c|c|c|}
\hline Day & Jan. & Feb. & Mar. & Apr. & May & June & July & Aug. & Sep. & Oct. ${ }^{1}$ & Nov. ${ }^{1}$ & Dec. ${ }^{1}$ \\
\hline 1 & 0.22 & 0.31 & 0.31 & 0.22 & 0.21 & 0.12 & 0.07 & 7.0 & 0.22 & 0.15 & 0.19 & 0.29 \\
\hline 3 & .34 & .25 & .31 & .22 & .17 & .10 & .07 & 11 & 41 & 375 & .21 & .31 \\
\hline 4 & .29 & .24 & .30 & .23 & .19 & .10 & .07 & 1.5 & 6.7 & 136 & .21 & .31 \\
\hline 6 & .63 & .23 & .27 & .25 & .22 & .10 & .06 & .15 & 13 & 3.7 & .23 & .37 \\
\hline 7 & .51 & .27 & .29 & .26 & .20 & .10 & .06 & .13 & 74 & .31 & .24 & .35 \\
\hline 8 & .40 & .30 & .29 & .26 & .19 & .10 & .06 & .11 & 36 & .26 & .24 & .38 \\
\hline 9 & .42 & .29 & .29 & .27 & .18 & .10 & .06 & .10 & 5.4 & .25 & .25 & .29 \\
\hline 13 & .28 & .87 & .28 & .23 & .23 & .10 & .06 & .09 & .70 & .21 & 112 & .33 \\
\hline 14 & .28 & .46 & .28 & .23 & .23 & .09 & .07 & .08 & .20 & .20 & 35 & .34 \\
\hline 15 & .28 & .39 & .30 & .25 & .22 & .09 & .06 & .10 & .18 & .21 & 3.9 & .28 \\
\hline 16 & .25 & .32 & .53 & .27 & .22 & .09 & .06 & .18 & .16 & .21 & .40 & .24 \\
\hline 17 & .25 & .30 & .46 & .24 & .21 & .09 & .06 & .13 & .13 & .21 & .28 & .28 \\
\hline 18 & .28 & .33 & .32 & .25 & .18 & .09 & .06 & .10 & .13 & .22 & .27 & .30 \\
\hline 19 & .27 & .30 & .29 & .37 & .18 & .09 & .06 & 4.2 & .14 & .23 & .27 & .32 \\
\hline 20 & .29 & .30 & .29 & .32 & .18 & .07 & .06 & 196 & .14 & .22 & .28 & .37 \\
\hline 21 & .29 & .28 & .27 & .25 & .18 & .07 & .06 & 7.7 & .13 & .23 & .27 & .39 \\
\hline 27 & .29 & .34 & .24 & .20 & .15 & .08 & 14 & 12 & .14 & .20 & .23 & .23 \\
\hline 28 & .29 & .37 & .22 & .19 & .14 & .08 & 25 & 5.7 & .14 & .22 & .23 & .27 \\
\hline 29 & .29 & --- & .23 & .18 & .14 & .08 & 27 & 1.5 & .14 & .22 & .25 & .29 \\
\hline 30 & .29 & --- & .25 & .18 & .13 & .07 & 24 & 7.7 & .13 & .18 & .27 & e. 35 \\
\hline 31 & .30 & --- & .25 & --- & .12 & --- & 14 & 1.4 & --- & .17 & --- & .32 \\
\hline TOTAL & 9.75 & 9.00 & 9.22 & 7.30 & 5.76 & 2.67 & 179.41 & 314.47 & 306.33 & 544.83 & 157.87 & 11.41 \\
\hline MEAN & .31 & .32 & .30 & .24 & .19 & .09 & 5.79 & 1.1 & 1.2 & 17.6 & 5.26 & .37 \\
\hline MAX & .63 & .87 & .53 & .37 & .23 & .12 & 62 & 196 & 100 & 375 & 112 & 1.7 \\
\hline MIN & .22 & .23 & .22 & .18 & .12 & .06 & .06 & .08 & .10 & .15 & .19 & .23 \\
\hline MED & .29 & .30 & .29 & .24 & .18 & .09 & .07 & .73 & .17 & .22 & .25 & .32 \\
\hline AC-FT & 19 & 18 & 18 & 14 & 11 & 5.3 & 356 & 624 & 608 & 1,080 & 313 & 23 \\
\hline CFSM & .00 & .00 & .00 & .00 & .00 & .00 & .01 & .02 & .02 & .04 & .01 & .00 \\
\hline CAL YR 2003 & $3 \quad \mathrm{TO}$ & L $1,558.02$ & MEAN 4.27 & MA & 375 & 0.06 & 0.25 & AC-FT 3,090 & CFSM & & & \\
\hline
\end{tabular}

${ }^{1}$ Month in which data are provisional, subject to revision. 
Table 12. Discharge data, Polacca Wash near Second Mesa, Arizona (09400568), calendar year 2003

[Dashes indicate no data]

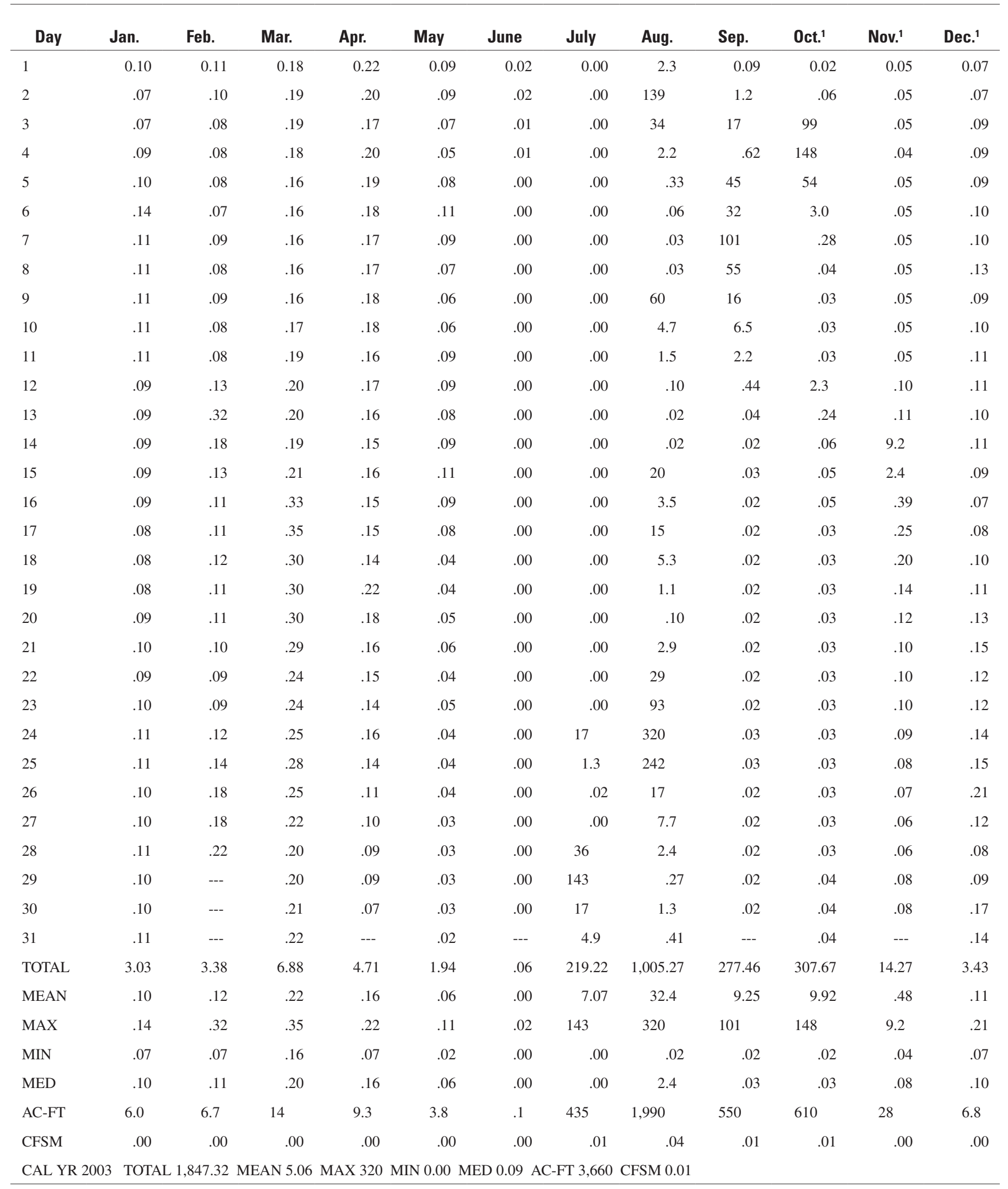

${ }^{1}$ Month in which data are provisional, subject to revision. 
Table 13. Date that data collection began and drainage areas for streamflow-gaging stations, Black Mesa area, Arizona

\begin{tabular}{lccc}
\hline \multicolumn{1}{c}{ Station name } & Station number & Date data collection began & $\begin{array}{c}\text { Drainage area } \\
\text { (square miles) }\end{array}$ \\
\hline Moenkopi Wash at Moenkopi & 09401260 & July 1976 & 1,629 \\
Laguna Creek at Dennehotso & 09379180 & July 1996 & 414 \\
Dinnebito Wash near Sand Springs & 09401110 & June 1993 & 473 \\
Polacca Wash near Second Mesa & 09400568 & April 1994 & 905 \\
\hline
\end{tabular}


A. Annual precipitation at Betatakin, Arizona, calendar years 1976-2002 (National Weather Service)

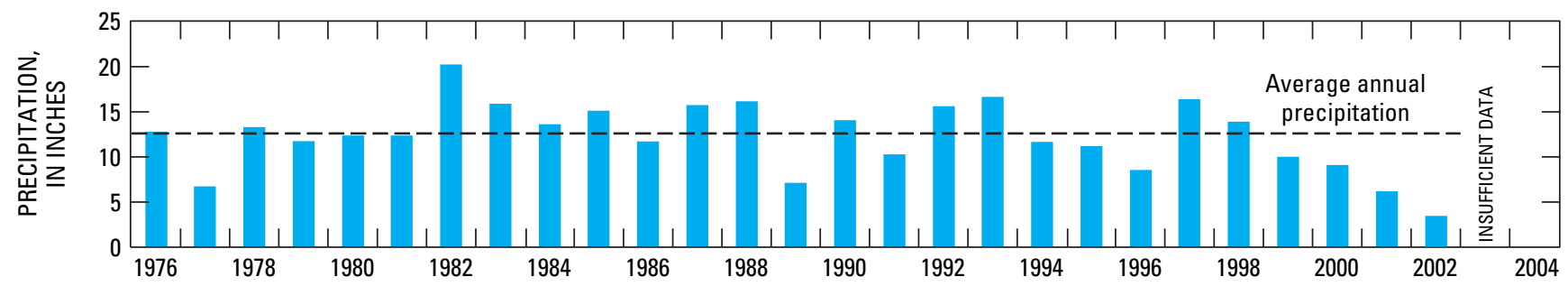

B. Annual average discharge for calendar years 1977-2003

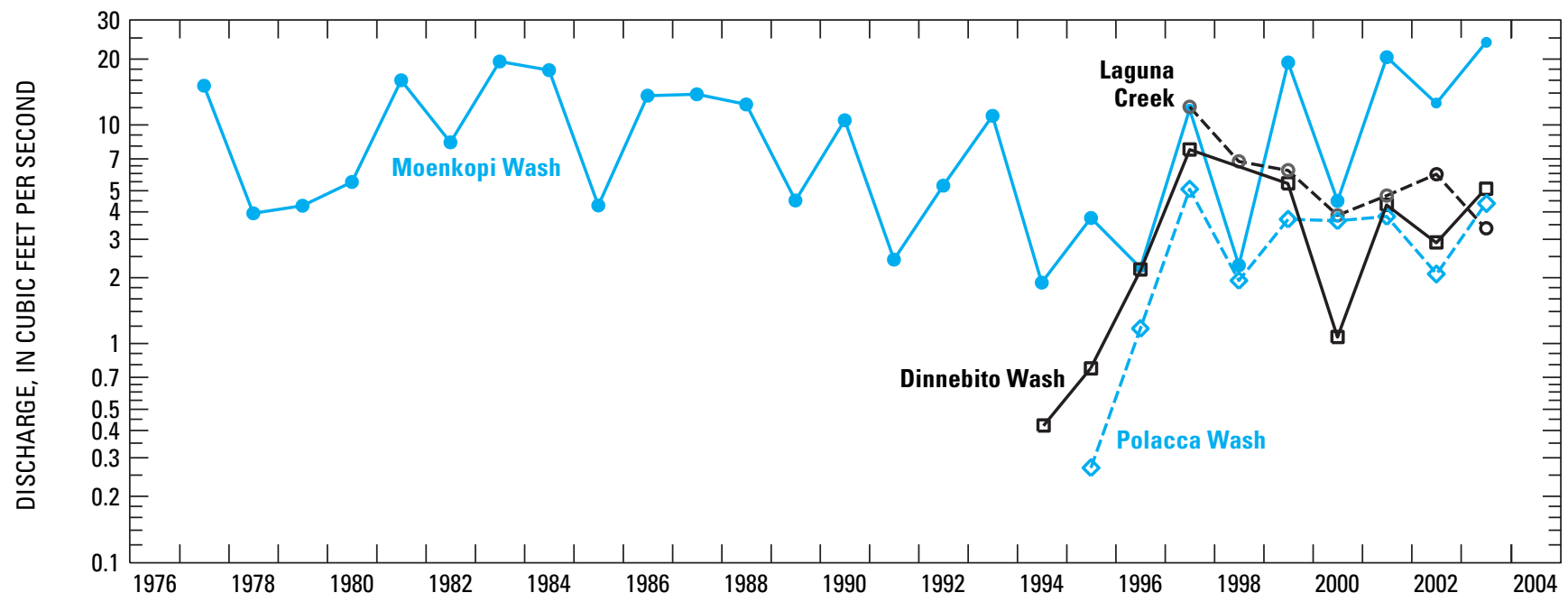

C. Median discharge for November, December, January, and February for water years 1977-2003

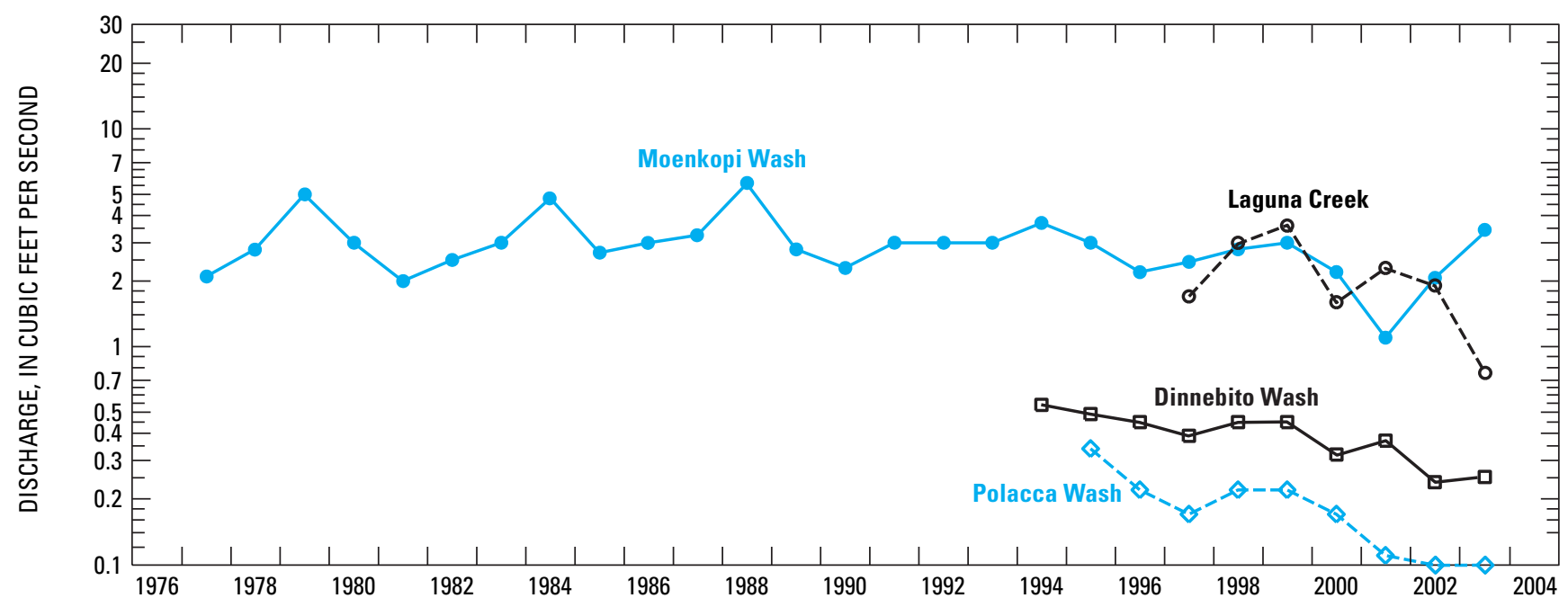

Figure 11. Annual precipitation at Betatakin, Arizona, and streamflow characteristics at Moenkopi Wash (09401260), Laguna Creek (09379180), Dinnebito Wash (09401110), and Polacca Wash (09400568), Black Mesa area, Arizona. A, Annual precipitation at Betatakin, Arizona, calendar years 1976-2002 (National Weather Service); B, Annual discharge for calendar years 1977-2003; $\boldsymbol{C}$, Median discharge for November, December, January, and February for water years 1977-2003. 
Also, evapotranspiration from streams is at a minimum during the winter. During the summer, much of the flow in streams evaporates or is transpired by plants. The median flow for November, December, January, and February, rather than the average flow, is used to estimate ground-water discharge because the median is less affected by occasional winter runoff.

The median flow for November, December, January, and February is an index of ground-water discharge rather than an absolute estimate of discharge. A more rigorous and accurate estimate would include detailed evaluations of streamflow hydrographs, flows into and out of bank storage, gain and loss of streamflow as it moves down the stream channel, and interaction of ground water in the $\mathrm{N}$ aquifer with ground water in the shallow alluvial aquifers in the stream valleys. The median winter flow, however, is useful as a consistent index for evaluating possible time trends in ground-water discharge.

Median winter flows were calculated for the 2003 water year; thus, daily mean flows for November and December 2002 (Truini and Thomas, 2004) were combined with daily mean flows for January and February 2003. These median winter flows were $3.45 \mathrm{ft}^{3} / \mathrm{s}$ for Moenkopi Wash, $0.75 \mathrm{ft}^{3} / \mathrm{s}$ for Laguna Creek, $0.25 \mathrm{ft}^{3} / \mathrm{s}$ for Dinnebito Wash, and $0.10 \mathrm{ft}^{3} / \mathrm{s}$ for Polacca Wash (fig. 11C). Since 1995, the median flows for Moenkopi Wash, Dinnebito Wash, and Polacca Wash have generally decreased; however, in 2003 flows for Moenkopi Wash and Dinnebito Wash increased, and flow for Polacca Wash remained constant (fig. 11C). Median flows for Laguna Creek are only available since 1997, and there is no consistent trend in these flows. Annual precipitation at Betatakin, about 15 miles west of Kayenta, has been less than average for 6 of the 9 years since 1995 (fig. 11A). Precipitation data for 2003 are incomplete.

\section{Water Chemistry}

Water samples are collected from selected wells and springs each year of the Black Mesa monitoring program. Field measurements are made and water samples are analyzed for major ions, nutrients, iron, boron, and arsenic. Samples are collected from 12 wells and 4 springs in each year of the program-from the same 8 wells every year and from the other 4 wells on a rotational basis. Since 1989, samples have been collected from the same 4 springs. Long-term data for specific conductance, total dissolved solids, chloride, and sulfate for the wells and springs sampled each year are shown in the report published for that year. Historical data for other constituents for all the wells and springs are available from the USGS water-quality database (http://waterdata.usgs.gov/az/ nwis/qw) or can be found in the past monitoring reports that are cited in the "Previous Investigations" section of this report.

\section{Water Chemistry from Wells Completed in the N Aquifer}

The primary types of water in the $\mathrm{N}$ aquifer are calcium bicarbonate and sodium bicarbonate. Calcium bicarbonate water generally is in the recharge areas of the northern and northwestern parts of the Black Mesa area, and sodium bicarbonate water is in the area that is downgradient to the south and east (Lopes and Hoffmann, 1997). In 2004, water samples were collected from 12 wells completed in the $\mathrm{N}$ aquifer (fig. 9). Sample analyses indicated primarily sodium bicarbonate water except for samples from Kayenta PM2 and Red Lake PM1, which are on the western edge of the confined part of the aquifer.

Rough Rock PM5 yielded an appreciably higher dissolved-solids concentration $(649 \mathrm{mg} / \mathrm{L})$ than did the other 11 sites (fig. 12 and table 14). Concentrations of dissolved solids in samples from the other 11 wells ranged from 100 at Red Lake PM1 to 429 mg/L at Keams Canyon PM 2 (fig. 12 and table 14). There is no apparent areal trend in dissolved solids concentrations.

There are no appreciable long-term trends in the chemistry of water samples from 7 wells having more than 10 years of data (table 15 and fig. 13). In the 7 wells, there are small year-to-year variations in concentrations of dissolved solids, chloride, and sulfate; however, increasing or decreasing trends are not apparent. The chemistry of water samples from the Forest Lake NTUA 1 well has varied considerably between 1982 and 2004 (table 15 and fig. 13). This variation may be from inconsistent purging volumes of this deep well $(2,674 \mathrm{ft})$ that has multiple screens throughout an interval of about $800 \mathrm{ft}$.

Constituents analyzed from the 12 well samples were compared to U.S. Environmental Protection Agency (USEPA) Primary and Secondary Drinking-Water Regulations (U.S. Environmental Protection Agency, 2002). Maximum Contaminant Levels (MCLs), which are the primary regulations, are legally enforceable standards that apply to public water systems. MCLs protect drinking-water quality by limiting the levels of specific contaminants that can adversely affect public health. Secondary Maximum Contaminant Levels (SMCLs) provide guidelines for the control of contaminants that may cause cosmetic effects (such as skin or tooth discoloration) or aesthetic effects (such as taste, odor, or color) in drinking water. The USEPA recommends compliance with SMCLs for public water systems; however, compliance is not required.

The concentrations of most of the analyzed constituents from the 12 wells sampled in 2004 were less than MCLs and SMCLs (table 14). The $\mathrm{pH}$, however, exceeded the SMCL maximum $\mathrm{pH}$ of 8.5 units in samples from 9 of the 12 wells. The dissolved-solids SMCL of $500 \mathrm{mg} / \mathrm{L}$ was exceeded in the sample from Rough Rock PM5 (649 mg/L). Samples from two wells, Keams Canyon PM3 (41 $\mu \mathrm{g} / \mathrm{L})$ and Rough Rock PM5 (48 $\mu \mathrm{g} / \mathrm{L}$ ), had arsenic concentrations that exceeded the MCL of $10 \mu \mathrm{g} / \mathrm{L}$ (http://www.epa.gov/safewater/mcl.html\#mcls). 


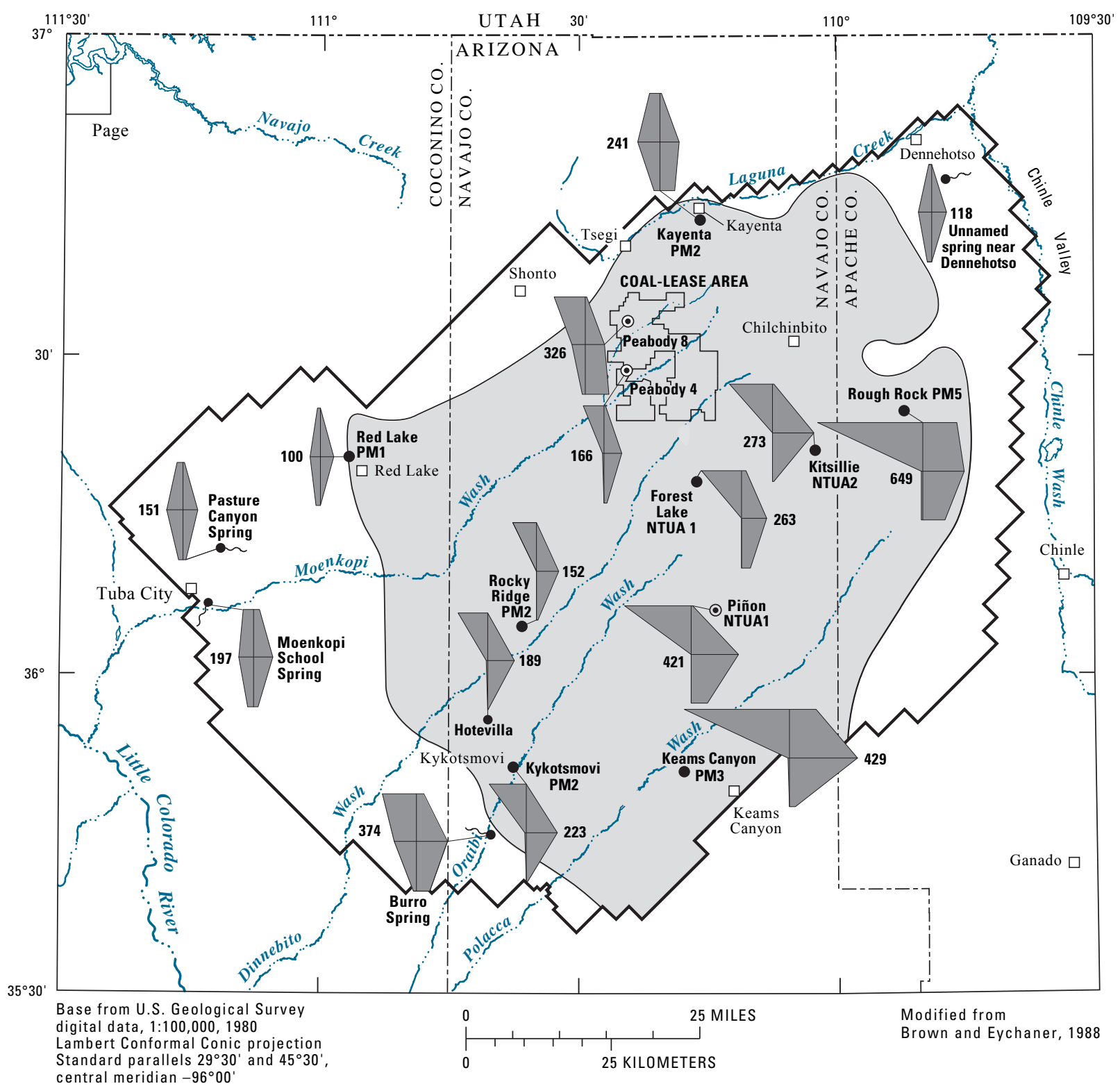

EXPLANATION

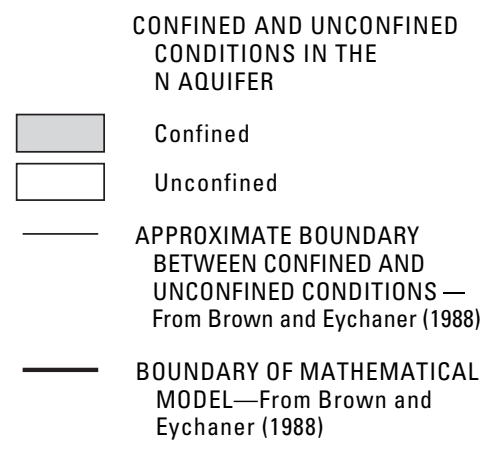

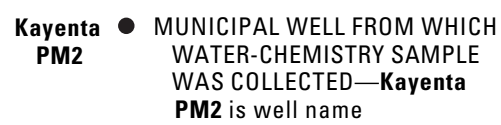

$\odot \quad$ INDUSTRIAL WELL FROM WHICH

Peabody 8 WATER-CHEMISTRY SAMPLE WAS COLLECTED

on SPRING AT WHICH DISCHARGE

Burro WAS MEASURED AND WATER-

Spring CHEMISTRY SAMPLE WAS

COLLECTED

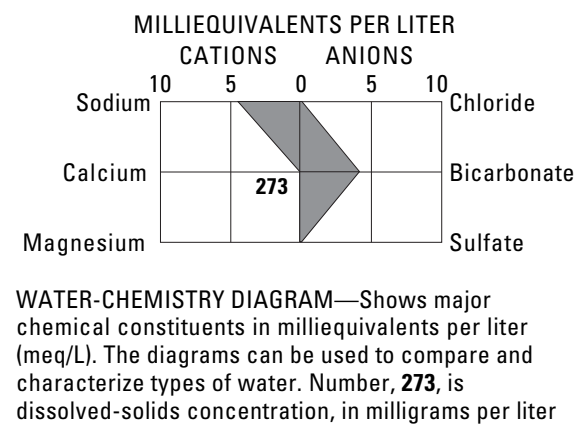

Figure 12. Water chemistry and distribution of dissolved solids in the N aquifer, Black Mesa area, Arizona, 2004. 
Table 14. Physical properties and chemical analyses of water from selected industrial and municipal wells completed in the $\mathrm{N}$ aquifer, Black Mesa area, Arizona, 2004

$\left[{ }^{\circ} \mathrm{C}\right.$, degrees Celsius; $\mu \mathrm{S} / \mathrm{cm}$, microsiemens per centimeter at $25^{\circ} \mathrm{C} ; \mathrm{mg} / \mathrm{L}$, milligrams per liter; $\mu \mathrm{g} / \mathrm{L}$, micrograms per liter; $<$, less than. Dashes indicate no data]

\begin{tabular}{|c|c|c|c|c|c|}
\hline Common well name & $\begin{array}{l}\text { U.S. Geological Survey } \\
\text { identification number }\end{array}$ & Date of sample & $\begin{array}{l}\text { Temperature, field } \\
\left({ }^{\circ} \mathrm{C}\right)\end{array}$ & $\begin{array}{c}\text { Specific } \\
\text { conductance, field } \\
(\mu \mathrm{S} / \mathrm{cm})\end{array}$ & $\begin{array}{c}\text { pH, field } \\
\text { (units) }\end{array}$ \\
\hline Forest Lake NTUA1 & 361737110180301 & 04-07-04 & 28.4 & 222 & 9.3 \\
\hline Hotevilla PM 1 & 355518110400301 & 04-05-04 & 24.3 & 258 & 9.6 \\
\hline Kayenta PM 2 & 364344110151201 & $03-30-04$ & 16 & 303 & 8.0 \\
\hline Keams Canyon PM 2 & 355023110182701 & $04-05-04$ & 19.5 & 945 & 9.1 \\
\hline Kitsillie NTUA 2 & 362043110030501 & $05-11-04$ & 28.7 & 367 & 9.7 \\
\hline Kykotsmovi PM 2 & 355215110375001 & 04-06-04 & 22 & 261 & 9.8 \\
\hline Piñon NTUA 1 & 360527110122501 & $04-08-04$ & 25.9 & 691 & 9.9 \\
\hline Rough Rock PM5 & 362418109514601 & $03-30-04$ & 21.5 & 653 & 8.8 \\
\hline Red Lake PM 1 & 361933110565001 & 03-29-04 & 17.1 & 131 & 8.3 \\
\hline Rocky Ridge PM 2 & 360418110352701 & 04-07-04 & 26.5 & 170 & 9.4 \\
\hline
\end{tabular}

\begin{tabular}{|c|c|c|c|c|c|}
\hline Common well name & $\begin{array}{c}\text { Alkalinity, field, } \\
\text { dissolved } \\
\text { (mg/L as } \mathrm{CaCO}_{3} \text { ) }\end{array}$ & $\begin{array}{c}\text { Nitrogen, } \mathrm{NO}_{2}+\mathrm{NO}_{3^{\prime}} \\
\text { dissolved } \\
(\mathrm{mg} / \mathrm{L} \text { as N})\end{array}$ & $\begin{array}{l}\text { Phosphorus, ortho, } \\
\text { dissolved } \\
\text { (mg/L as P) }\end{array}$ & $\begin{array}{c}\text { Calcium, } \\
\text { dissolved } \\
\text { (mg/L as Ca) }\end{array}$ & $\begin{array}{c}\text { Magnesium, } \\
\text { dissolved } \\
\text { (mg/L as } \mathrm{Mg} \text { ) }\end{array}$ \\
\hline Forest Lake NTUA1 & 130 & 0.59 & $<.02$ & 0.84 & 0.08 \\
\hline Hotevilla PM 1 & 143 & 1.1 & ${ }^{1} .02$ & .68 & .02 \\
\hline Kayenta PM 2 & 105 & .99 & $<.02$ & 45 & 7.0 \\
\hline Keams Canyon PM 2 & 354 & $<.06$ & $<.02$ & .84 & .16 \\
\hline Kitsillie NTUA 2 & 211 & 1.4 & ${ }^{1} .01$ & .53 & .01 \\
\hline Kykotsmovi PM 2 & 168 & 1.2 & .03 & .52 & .02 \\
\hline Peabody 4 & 92 & 1.03 & $<.02$ & 4.6 & .03 \\
\hline Peabody 8 & 102 & 1.7 & $<.02$ & 26 & 3.9 \\
\hline Piñon NTUA1 & 248 & 1.3 & ${ }^{1} .02$ & 1.2 & .19 \\
\hline Rough Rock PM 5 & 226 & 1.3 & ${ }^{1} .01$ & 2.2 & .3 \\
\hline Red Lake PM 1 & 72.4 & 1.35 & $<.2$ & 19 & 5.61 \\
\hline Rocky Ridge PM 2 & 116 & 1.31 & .02 & .43 & .012 \\
\hline
\end{tabular}


Table 14. Physical properties and chemical analyses of water from selected industrial and municipal wells completed in the $\mathrm{N}$ aquifer, Black Mesa area, Arizona, 2004-Continued

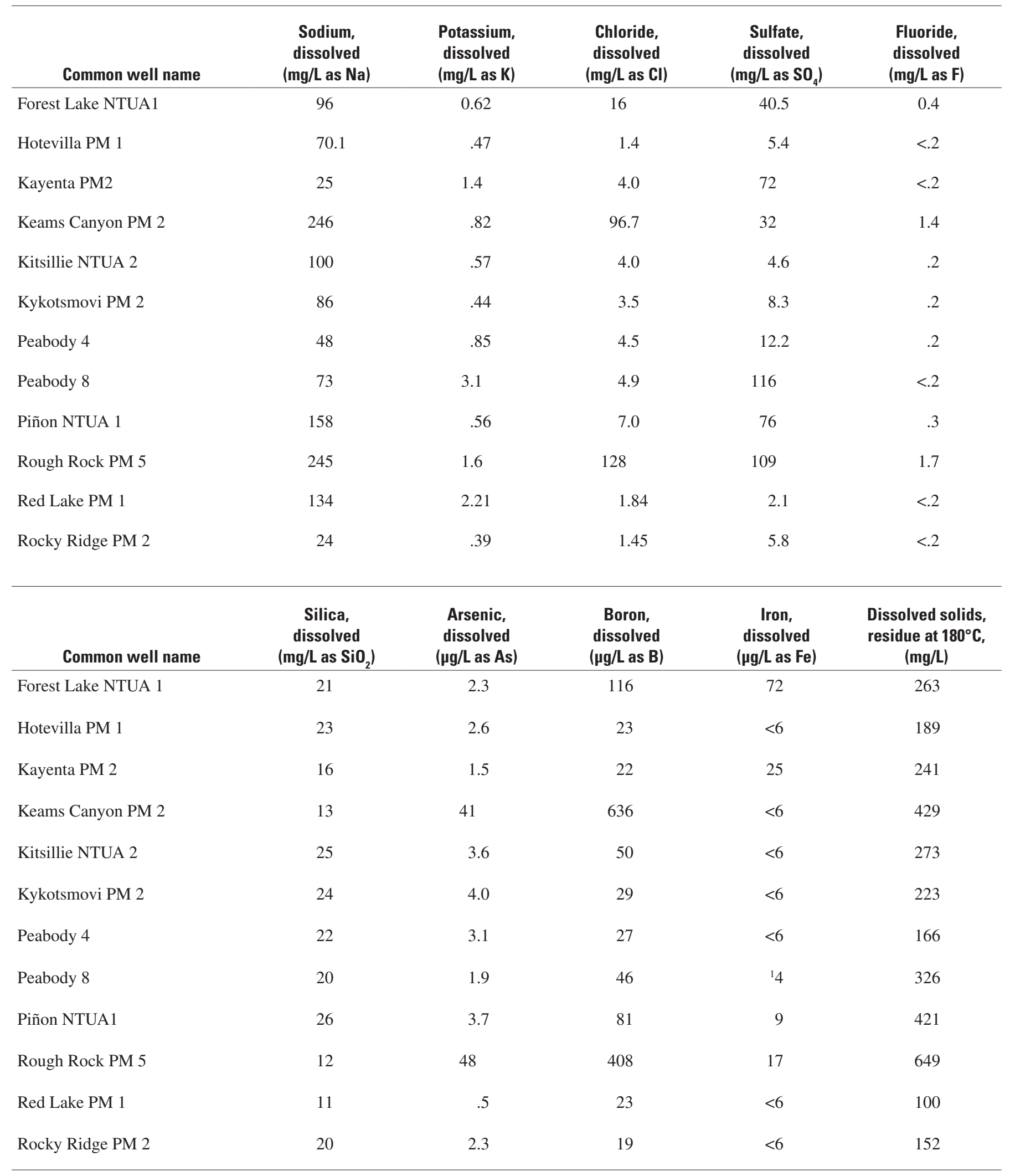

${ }^{1}$ Estimated value. 
Table 15. Specific conductance and concentrations of selected chemical constituents in water from industrial and municipal wells completed in the N aquifer, Black Mesa area, Arizona, 1974-2004

$\left[\mathrm{\mu S} / \mathrm{cm}\right.$, microsiemens per centimeter at $25^{\circ} \mathrm{C} ;{ }^{\circ} \mathrm{C}$, degrees Celsius; $\mathrm{mg} / \mathrm{L}$, milligrams per liter; $<$, less than. Dashes indicate no data]

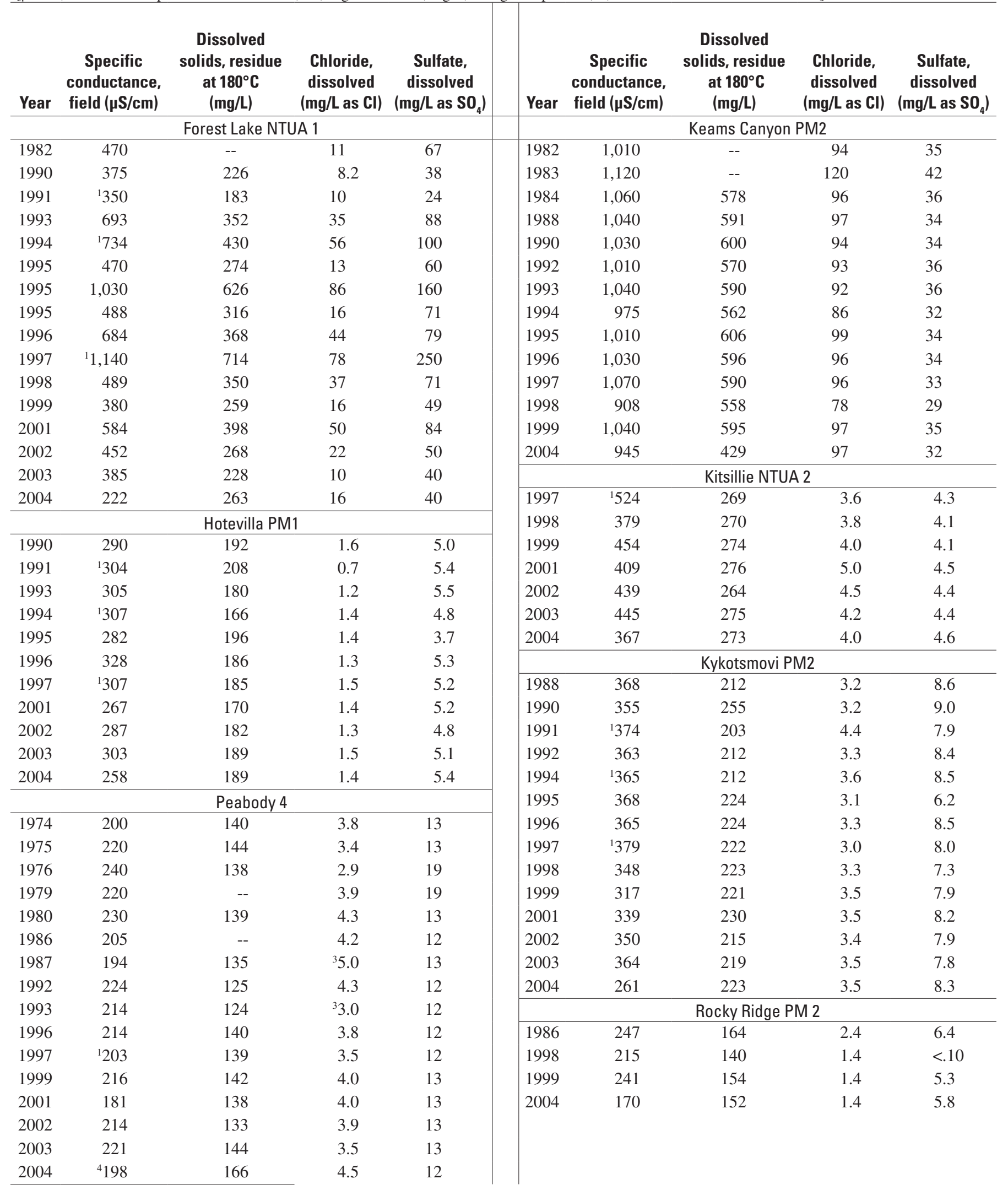

See footnotes at end of table. 
Table 15. Specific conductance and concentrations of selected chemical constituents in water from industrial and municipal wells completed in the N aquifer, Black Mesa area, Arizona, 1974-2004_Continued

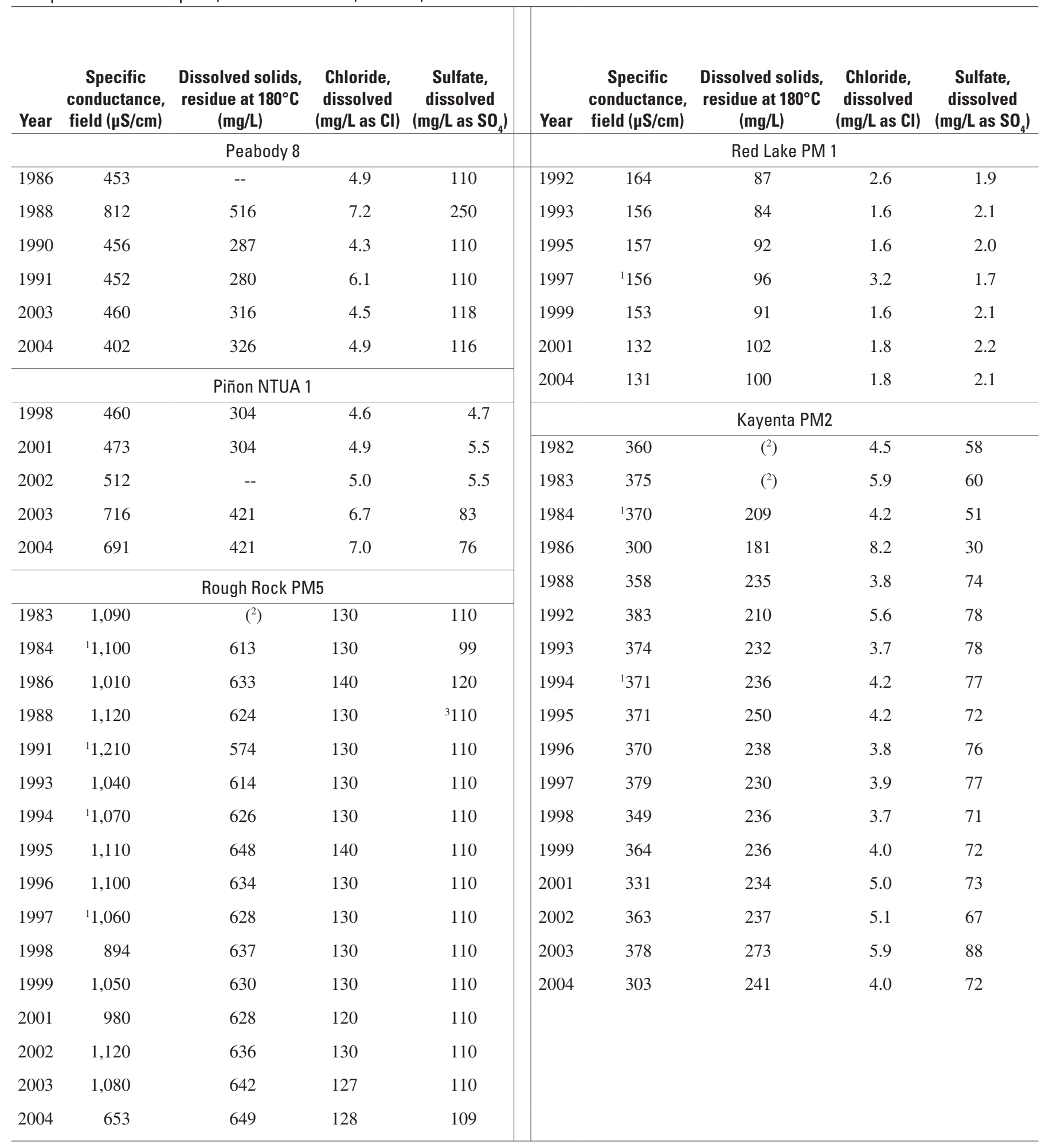

${ }^{1}$ Value is different in Black Mesa monitoring reports printed before 2000. The earlier reports showed values determined by laboratory analysis.

${ }^{2}$ Value is different in Black Mesa monitoring reports printed before 2000. The earlier reports showed values determined by the sum of constituents.

${ }^{3}$ Value is different in Black Mesa monitoring reports printed before 2000. The earlier reports applied a different rounding definition.

${ }^{4}$ Estimated lab value listed owing to questionable field measurement. 


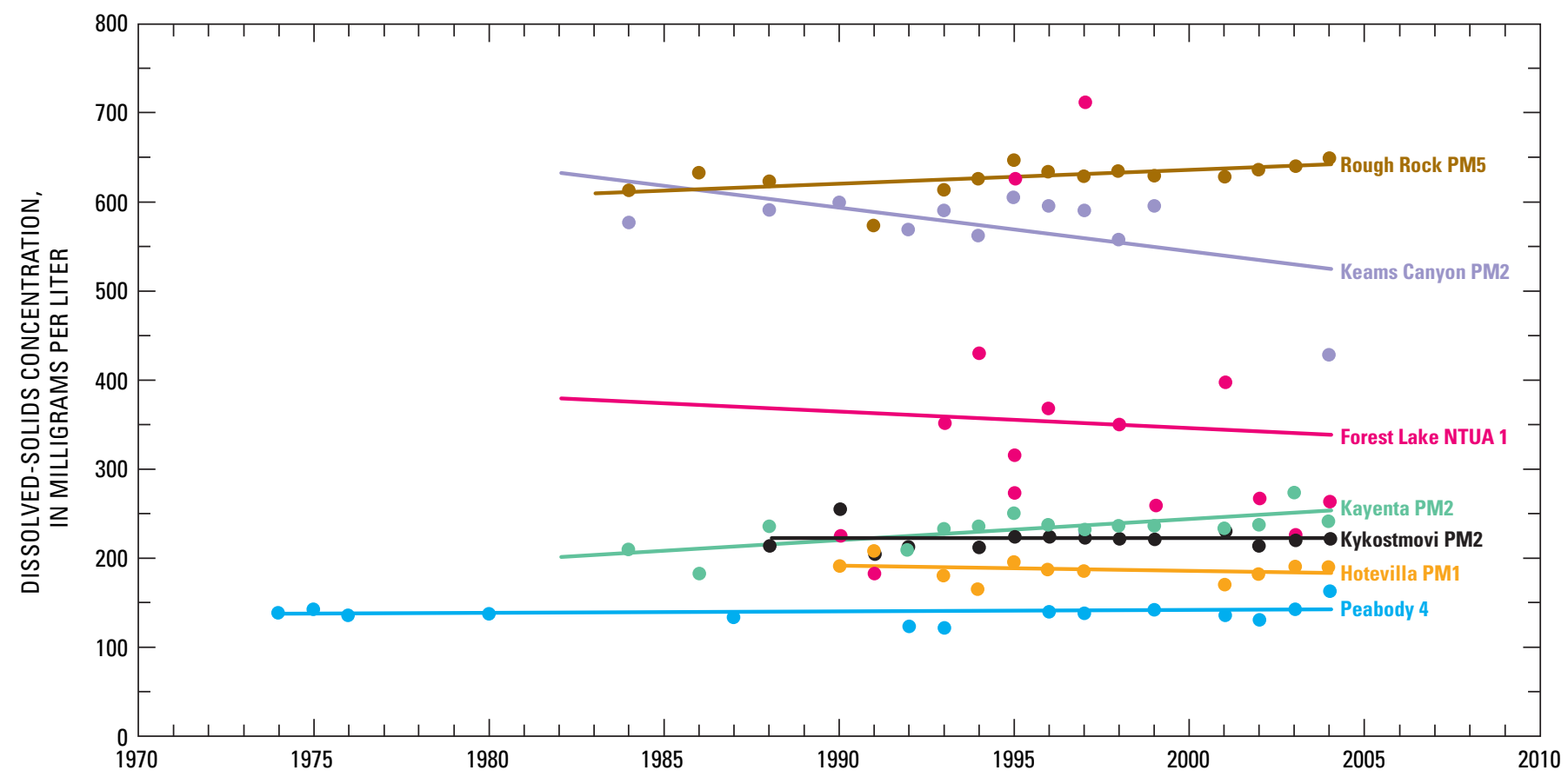

Figure 13. Dissolved-solids concentrations with linear trend lines for water from selected wells, Black Mesa area, Arizona, 1974-2004.

\section{Water Chemistry from Springs that Discharge from the N Aquifer}

In 2004, water samples were collected from four springs in the study area. Burro Spring is in the southern part of the study area, the unnamed spring near Dennehotso is in the northeastern part, and Moenkopi School Spring and Pasture Canyon Spring are in the western part (fig. 9). All the springs discharge water from unconfined parts of the $\mathrm{N}$ aquifer. At Burro Spring, samples are collected from a metal pipe that discharges from a holding tank. At Moenkopi School Spring, samples are collected from a horizontal metal pipe that is developed into the hillside. At the unnamed spring near Dennehotso, samples are collected from a cavity dug into the sand where the water discharges from the bedrock. At Pasture Canyon Spring, samples are collected from a pipe at the end of a channel and approximately 50 feet away from the spring.

Two water types were identified from the samples from the four springs. The unnamed spring near Dennehotso and
Pasture Canyon Spring yielded a calcium bicarbonate type water, and Burro Spring and Moenkopi School Spring yielded a calcium sodium bicarbonate type water (fig. 12). Samples from the unnamed spring near Dennehotso, Moenkopi School Spring, and Pasture Canyon Spring had low dissolved-solids concentrations that ranged from 117 to $196 \mathrm{mg} / \mathrm{L}$ (table 16). The sample from Burro Spring had a dissolved-solids concentration of $337 \mathrm{mg} / \mathrm{L}$. Concentrations of all the analyzed constituents in samples from the four springs were less than current USEPA MCLs and SMCLs (U.S. Environmental Protection Agency, 2002).

No long-term trends, since the mid-1980s, are apparent in concentrations of dissolved solids, chloride, and sulfate in water samples from the unnamed spring near Dennehotso and Pasture Canyon Spring (table 17 and fig. 14). There may be an increasing trend in concentrations of dissolved solids and chloride at Burro Spring and Moenkopi School Spring (figs. 14 and 15; table 17). 
Table 16. Physical properties and chemical analyses of water from selected springs that discharge from the $\mathrm{N}$ aquifer,

Black Mesa area, Arizona, 2004

$\left[{ }^{\circ} \mathrm{C}\right.$, degree Celsius; $\mu \mathrm{S} / \mathrm{cm}$, microsiemens per centimeter at $25^{\circ} \mathrm{C} ; \mathrm{mg} / \mathrm{L}$, milligrams per liter; $\mu \mathrm{g} / \mathrm{L}$, micrograms per liter; $<$, less than. Dashes indicate no data; e, estimated]

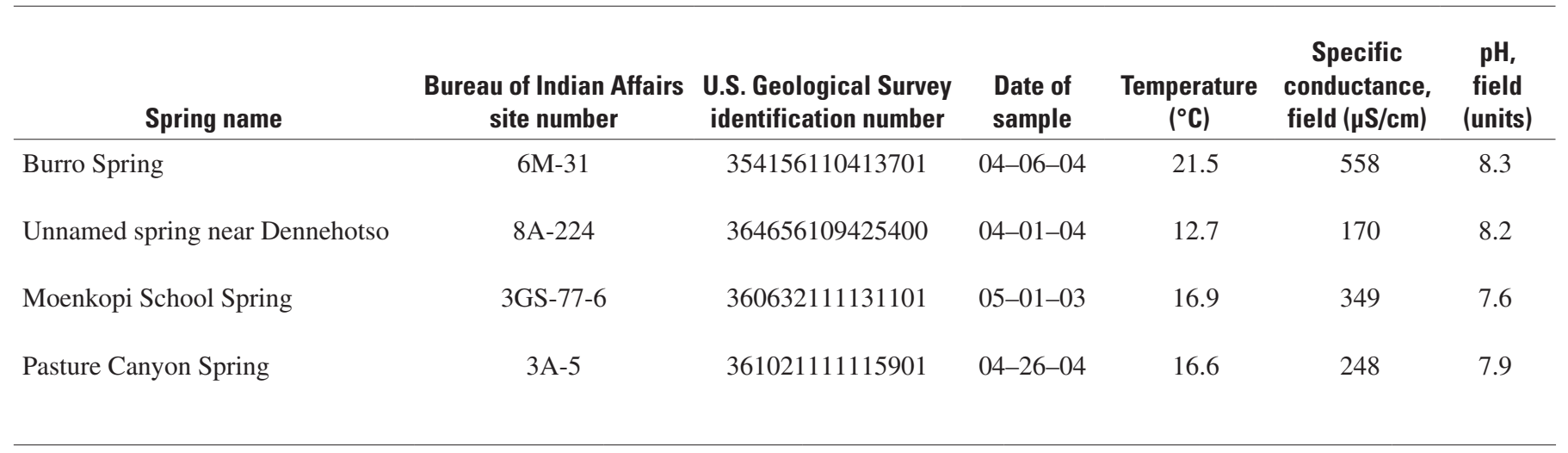

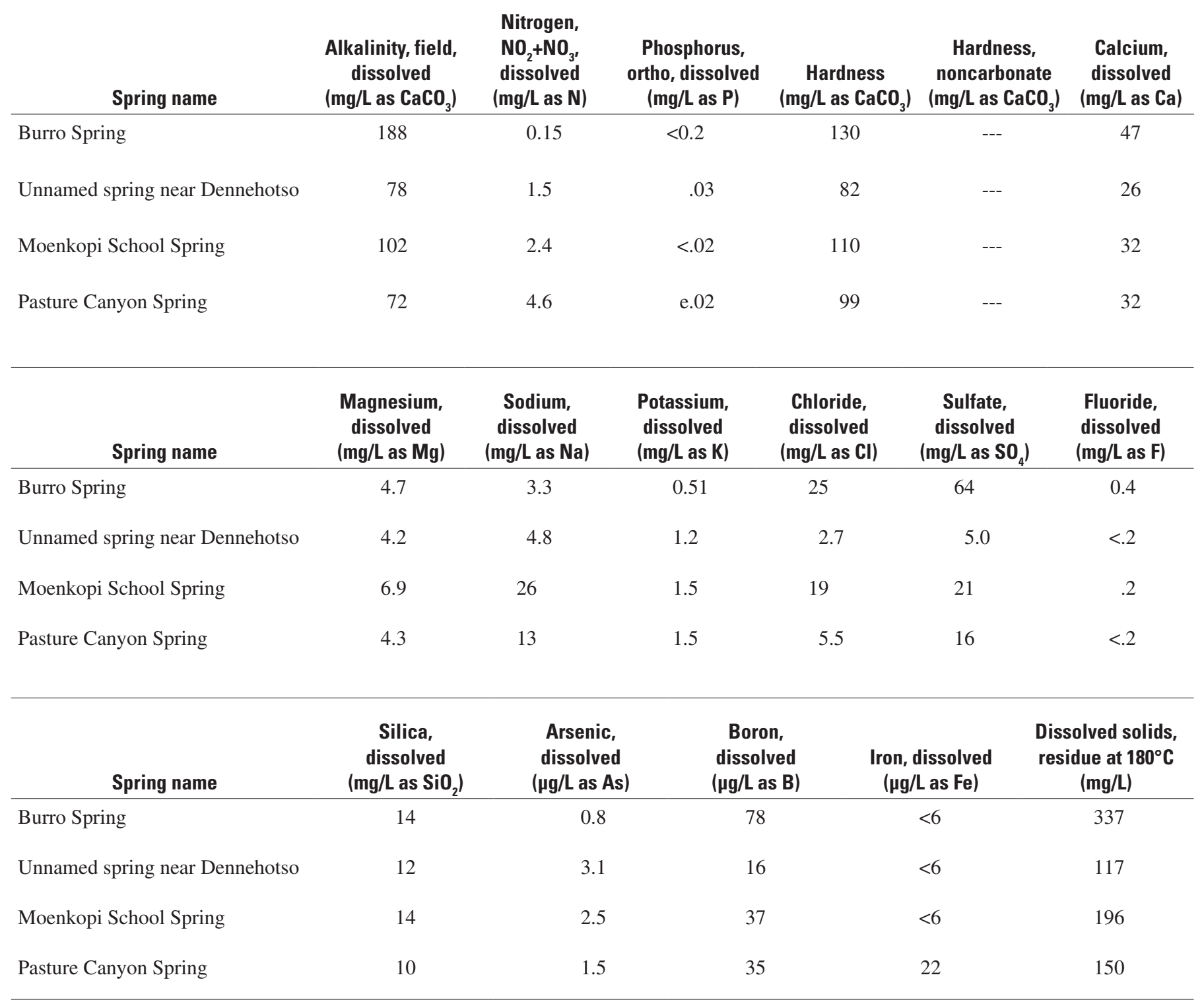


Table 17. Specific conductance and concentrations of selected chemical constituents in water from selected springs that discharge from the $\mathrm{N}$ aquifer, Black Mesa area, Arizona, 1948-2004

$\left[\mu \mathrm{S} / \mathrm{cm}\right.$, microsiemens per centimeter at $25^{\circ} \mathrm{C} ; \mathrm{mg} / \mathrm{L}$, milligrams per liter; ${ }^{\circ} \mathrm{C}$, degrees Celsius. Dashes indicate no data]

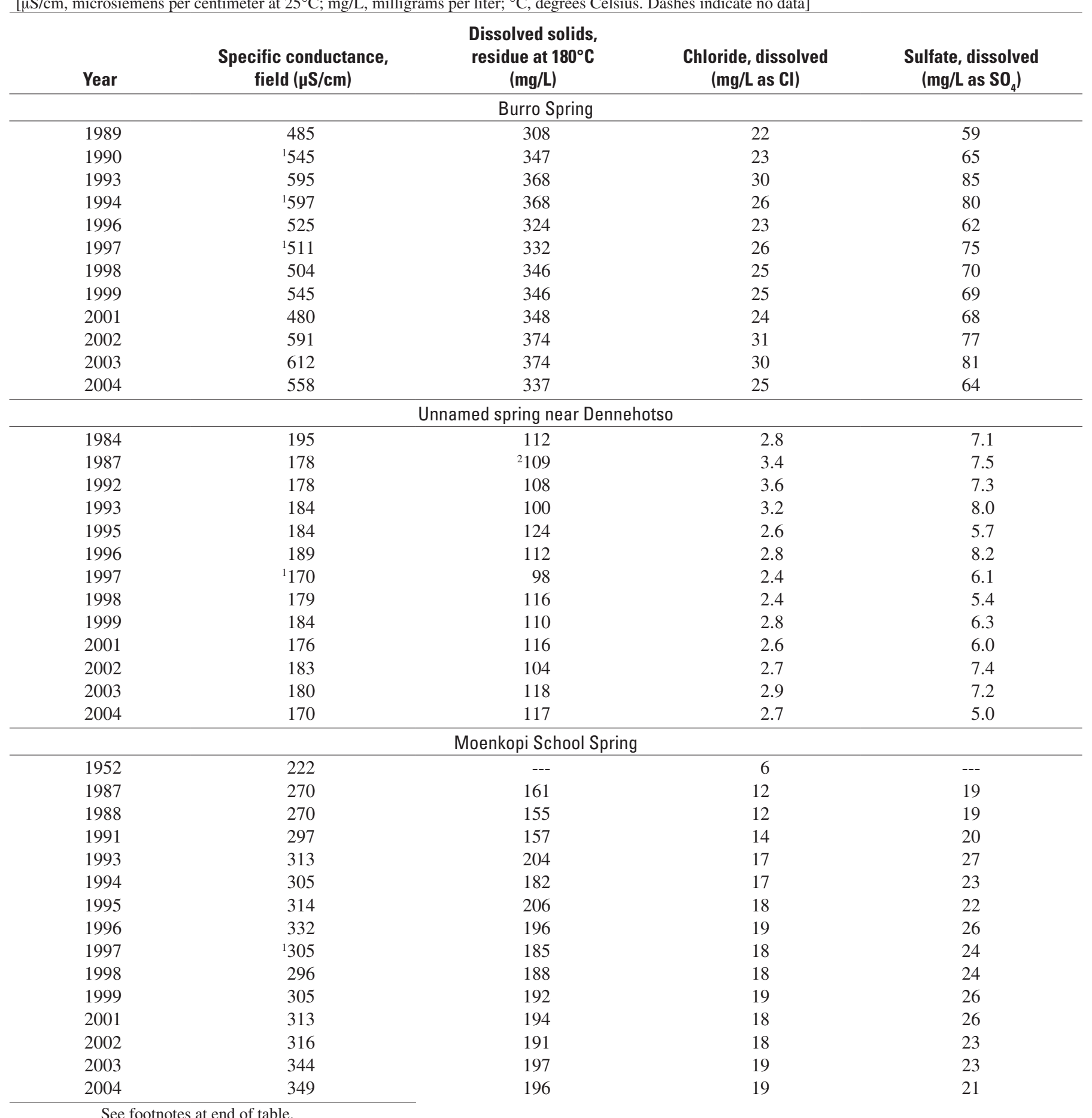

See footnotes at end of table. 
Table 17. Specific conductance and concentrations of selected chemical constituents in water from selected springs that discharge from the N aquifer, Black Mesa area, Arizona, 1948-2004-Continued

\begin{tabular}{|c|c|c|c|c|}
\hline Year & $\begin{array}{c}\text { Specific conductance, } \\
\text { field }(\mu \mathrm{S} / \mathrm{cm})\end{array}$ & $\begin{array}{c}\text { Dissolved solids, } \\
\text { residue at } 180^{\circ} \mathrm{C} \\
\text { (mg/L) }\end{array}$ & $\begin{array}{l}\text { Chloride, dissolved } \\
\text { (mg/L as Cl) }\end{array}$ & $\begin{array}{c}\text { Sulfate, dissolved } \\
\left(\mathrm{mg} / \mathrm{L} \text { as } \mathrm{SO}_{4}\right)\end{array}$ \\
\hline \multicolumn{5}{|c|}{ Pasture Canyon Spring } \\
\hline 1948 & ${ }^{1} 227$ & $\left({ }^{2}\right)$ & 5 & 13 \\
\hline 1982 & 240 & --- & 5.1 & 18 \\
\hline 1992 & 235 & 168 & 7.1 & 17 \\
\hline 1993 & 242 & 134 & 5.3 & 17 \\
\hline 1995 & 235 & 152 & 4.8 & 14 \\
\hline 1996 & 238 & 130 & 4.7 & 15 \\
\hline 1997 & 232 & 143 & 5.3 & 17 \\
\hline 1998 & 232 & 147 & 5.1 & 16 \\
\hline 2004 & 248 & 150 & 5.5 & 16 \\
\hline
\end{tabular}

${ }^{1}$ Value is different in Black Mesa monitoring reports before 2000. Earlier reports showed values determined by laboratory analysis.

${ }^{2}$ Value is different in Black Mesa monitoring reports before 2000. Earlier reports showed values determined by the sum of constituents.

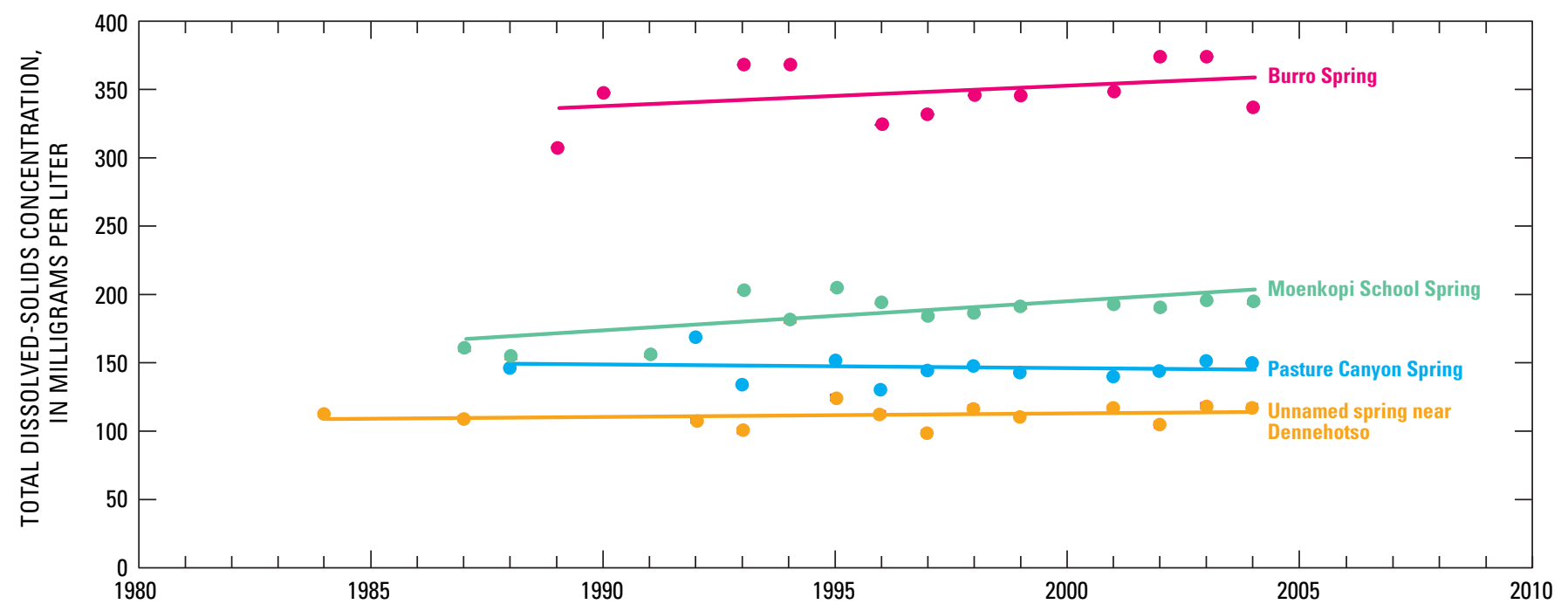

Figure 14. Dissolved-solids concentrations with linear trend lines for water from selected springs, Black Mesa area, Arizona, 1984-2004. 


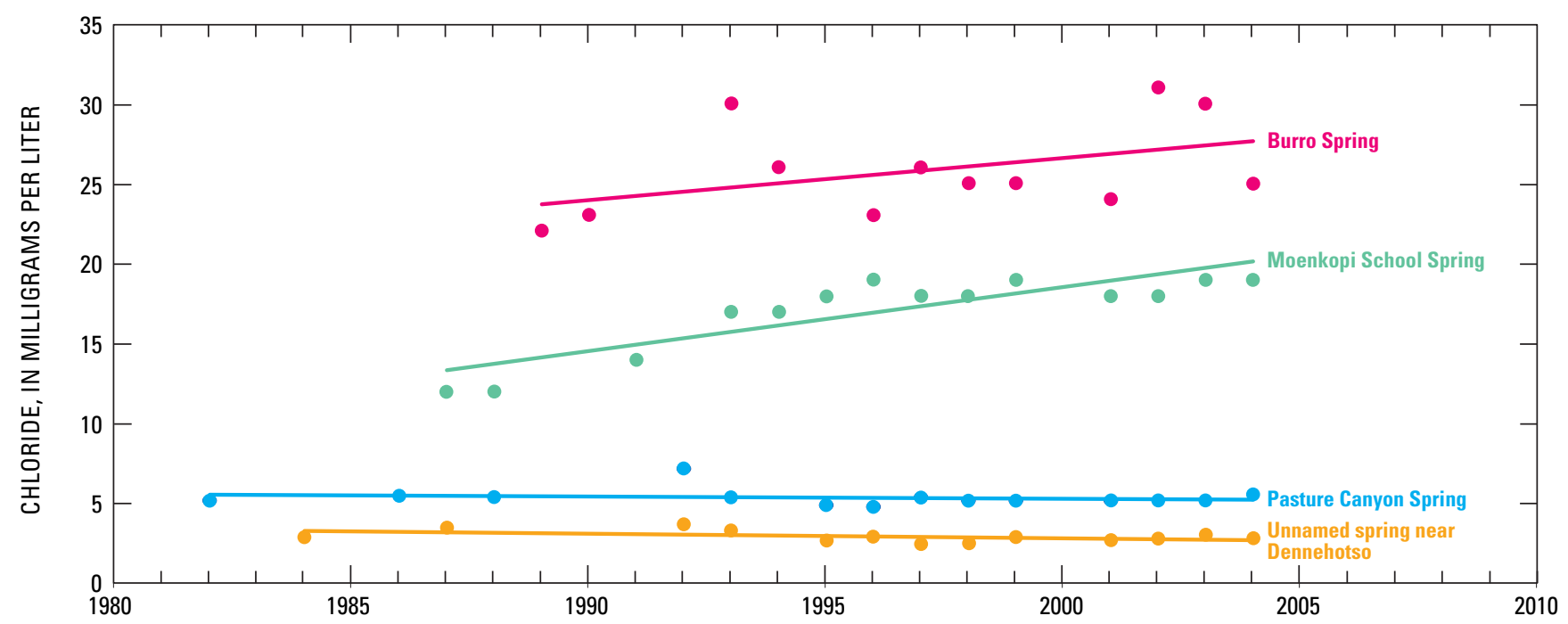

Figure 15. Chloride concentrations with linear trend lines for water from selected springs, Black Mesa area, Arizona, 1982-2004.

\section{Summary}

The $\mathrm{N}$ aquifer is the major source of water for industrial and municipal users in the Black Mesa area of northeastern Arizona. Availability of water is an important issue in the Black Mesa area because of continued industrial and municipal use, a growing population, and precipitation of about 6 to 14 in. per year.

This report presents results of ground-water, surfacewater, and water-chemistry monitoring in the Black Mesa area from January 2003 to September 2004. The monitoring data for 2003-04 are compared with data for 2002-03 and with historical data from the 1950s to the present.

In 2003, total ground-water withdrawals were 7,240 acre-ft, industrial withdrawals were 4,450 acre-ft, and municipal withdrawals were 2,790 acre-ft. From 2002 to 2003, total withdrawals decreased by 10 percent, municipal withdrawals decreased by 20 percent, and industrial withdrawals decreased by 4 percent. Flowmeter testing was completed for 24 municipal wells in June 2004. The median difference between pumping rates for the permanent meter and a test meter for all the sites tested was -2.9 percent. Differences ranged from -10.9 percent at Forest Lake NTUA 1 to +7.8 percent at Rough Rock NTUA 2 .

From 2003 to 2004, ground-water levels declined in 13 of 23 wells. The median water-level change for the 23 wells was $-0.2 \mathrm{ft}$. In unconfined areas, water levels declined in 6 of 12 wells, and the median change was $-0.1 \mathrm{ft}$. In the confined area, water levels declined in 7 of 11 wells, and the median change was $-2.7 \mathrm{ft}$.
For wells in the confined area, the annual median waterlevel change was $-1.8 \mathrm{ft}$, and there is no appreciable trend in the annual water-level changes from 1983 to 2004. For wells in unconfined areas, the annual median water-level change was $+0.2 \mathrm{ft}$, and there is no appreciable trend from 1983 to 2004 .

From the prestress period (prior to 1965) to 2004, the median water-level change in 26 wells was $-23.2 \mathrm{ft}$. Water levels in the 14 wells in the unconfined parts of the aquifer had a median change of $-6.1 \mathrm{ft}$, and the changes ranged from $-55.6 \mathrm{ft}$ to $+6.2 \mathrm{ft}$. Water levels in the 12 wells in the confined part of the aquifer had a median change of $-72.1 \mathrm{ft}$, and the changes ranged from $-205.1 \mathrm{ft}$ to $+15.3 \mathrm{ft}$.

Discharges were measured annually at four springs in 2003 and 2004. Between 2003 and 2004, spring flow decreased 50 percent at Burro Spring, decreased 26 percent at the unnamed spring near Dennehotso, increased 9 percent at Moenkopi School Spring, and stayed the same at Pasture Canyon Spring. For about the past 12 years, discharges in the four springs have fluctuated; however, increasing or decreasing trends are not apparent.

Annual average discharges at four streamflow-gaging stations-Moenkopi Wash, Laguna Creek, Dinnebito Wash, and Polacca Wash - vary considerably during the periods of record. No trends are apparent in streamflow at the four gaging stations. Median flows for November, December, January, and February of each water year are used as an index of groundwater discharge to those streams. Since 1995, the median winter flows have decreased in Moenkopi Wash, Dinnebito Wash, and Polacca Wash. Since 1997, there is no consistent trend in the median winter flow in Laguna Creek. 
In 2004, water samples were collected from 12 wells and analyzed for selected chemical constituents. Dissolved-solids concentrations ranged from 100 to $649 \mathrm{mg} / \mathrm{L}$, and samples from 11 of the wells had dissolved-solids concentrations less than $500 \mathrm{mg} / \mathrm{L}$. There are no appreciable trends in the chemistry of water samples from 7 wells with more than 10 years of data. Samples from Rough Rock PM5 exceeded the SMCL for dissolved solids (500 mg/L), and samples from 9 of the 12 wells exceeded the SMCL maximum for $\mathrm{pH}(8.5)$.

Dissolved-solids concentrations in water samples from the unnamed spring near Dennehotso, Pasture Canyon Spring, and Moenkopi School Spring ranged from 117 to $196 \mathrm{mg} / \mathrm{L}$, and the dissolved-solids concentration in the water sample from Burro Spring was $337 \mathrm{mg} / \mathrm{L}$. From the mid-1980s to 2004, long-term trends are not apparent in the concentrations of dissolved solids, chloride, and sulfate in water samples from the unnamed spring near Dennehotso and Pasture Canyon Spring. There may be an increasing trend in concentrations of dissolved solids and chloride at Burro Spring and Moenkopi School Spring.

\section{Selected References}

Boner, F.C., Davis, R.G., and Duet, N.R., 1992, Waterresources data for Arizona, water year 1991: U.S. Geological Survey Water-Data Report AZ-91-1, 411 p.

Boner, F.C., Garrett, W.B., and Konieczki, A.D., 1989, Water-resources data for Arizona, water year 1988: U.S. Geological Survey Water-Data Report AZ-88-1, 391 p.

Boner, F.C., Konieczki, A.D., and Davis, R.G., 1991, Water-resources data for Arizona, water year 1990: U.S. Geological Survey Water-Data Report AZ-90-1, 381 p.

Boner, F.C., Smith, C.F., Garrett, W.B., and Konieczki, A.D., 1990, Water-resources data for Arizona, water year 1989: U.S. Geological Survey Water-Data Report AZ-89-1, 383 p.

Brown, J.G., and Eychaner, J.H., 1988, Simulation of five ground-water withdrawal projections for the Black Mesa area, Navajo and Hopi Indian Reservations, Arizona: U.S. Geological Survey Water-Resources Investigations Report 88-4000, 51 p.

Cooley, M.E., Harshbarger, J.W., Akers, J.P., and Hardt, W.F., 1969, Regional hydrogeology of the Navajo and Hopi Indian Reservations, Arizona, New Mexico, and Utah: U.S. Geological Survey Professional Paper 521-A, 61 p.
Davis, G.E., Hardt, W.F., Thompson, L.K., and Cooley, M.E., 1963, Records of ground-water supplies, part 1, of Geohydrologic data in the Navajo and Hopi Indian Reservations, Arizona, New Mexico, and Utah: Arizona State Land Department Water- Resources Report 12-A, $159 \mathrm{p}$.

Dubiel, R.F., 1989, Sedimentology and revised nomenclature for the upper part of the upper Triassic Chinle Formation and the lower Jurassic Wingate Sandstone, northwestern New Mexico and northeastern Arizona, in Anderson, O.J., Lucas, S.G., Love, D.W., and Cather, S.M., eds., Southeastern Colorado Plateau: New Mexico Geological Society Fortieth Annual Field Conference, September 28-October 1, 1989, p. 213-223.

Eychaner, J.H., 1983, Geohydrology and effects of water use in the Black Mesa area, Navajo and Hopi Indian Reservations, Arizona: U.S. Geological Survey WaterSupply Paper 2201, 26 p.

Fisk, G.G., Duet, N.R., Evans, D.W., Angeroth, C.E., Castillo, N.K., and Longsworth, S.A., 2004, Water-resources data for Arizona, water year 2003: U.S. Geological Survey Water-Data Report AZ-03-1, 326 p.

GeoTrans, Inc., 1987, A two-dimensional finite-difference flow model simulating the effects of withdrawals to the $\mathrm{N}$ aquifer, Black Mesa area, Arizona: Boulder, Colorado, GeoTrans, Inc., report prepared for Peabody Western Coal Company.

Harshbarger, J.W., Lewis, D.D., Skibitzke, H.E., Heckler, W.L., and Kister, L.R., 1966, Arizona water: U.S. Geological Survey Water-Supply Paper 1648, 85 p.

Hart, R.J., and Sottilare, J.P., 1988, Progress report on the ground-water, surface-water, and quality-of-water monitoring program, Black Mesa area, northeastern Arizona-1987-88: U.S. Geological Survey Open-File Report 88-467, 27 p.

Hart, R.J., and Sottilare, J.P., 1989, Progress report on the ground-water, surface-water, and quality-of-water monitoring program, Black Mesa area, northeastern Arizona-1988-89: U.S. Geological Survey Open-File Report 89-383, 33 p.

Hill, G.W., 1985, Progress report on Black Mesa monitoring program-1984: U.S. Geological Survey Open-File Report 85-483, 24 p.

Hill, G.W., and Sottilare, J.P., 1987, Progress report on the ground-water, surface-water, and quality-of-water monitoring program, Black Mesa area, northeastern Arizona-1987: U.S. Geological Survey Open-File Report 87-458, 29 p. 
Hill, G.W., and Whetten, M.I., 1986, Progress report on Black Mesa monitoring program-1985-86: U.S. Geological Survey Open-File Report 86-414, 23 p.

HSIGeoTrans, Inc., 1993, Investigation of the N- and Daquifer geochemistry and flow characteristics using major ion and isotopic chemistry, petrography, rock stress analyses, and dendrochronology in the Black Mesa area, Arizona: Boulder, Colorado, HSIGeoTrans, Inc., report prepared for Peabody Coal Company.

HSIGeoTrans, Inc., and Waterstone Environmental Hydrology and Engineering, Inc., 1999, A three-dimensional flow model of the D and $\mathrm{N}$ aquifers, Black Mesa Basin, Arizona: Boulder, Colorado, HSIGeoTrans, Inc., and Waterstone Environmental Hydrology and Engineering, Inc., report prepared for Peabody Western Coal Company.

Kister, L.R., and Hatchett, J.L., 1963, Selected chemical analyses of the ground water, part 2 of Geohydrologic data in the Navajo and Hopi Indian Reservations, Arizona, New Mexico, and Utah: Arizona State Land Department Water-Resources Report 12-B, 58 p.

Littin, G.R., 1992, Results of ground-water, surface-water, and water-quality monitoring, Black Mesa area, northeastern Arizona-1990-91: U.S. Geological Survey WaterResources Investigations Report 92-4045, 32 p.

Littin, G.R., 1993, Results of ground-water, surface-water, and water-quality monitoring, Black Mesa area, northeastern Arizona-1991-92: U.S. Geological Survey WaterResources Investigations Report 93-4111, 23 p.

Littin, G.R., Baum, B.M., and Truini, Margot, 1999, Groundwater, surface-water, and water-chemistry data, Black Mesa area, northeastern Arizona-1999: U.S. Geological Survey Open-File Report 98-653, 27 p.

Littin, G.R., and Monroe, S.A., 1995a, Results of groundwater, surface-water, and water-quality monitoring, Black Mesa area, northeastern Arizona-1992-93: U.S. Geological Survey Water-Resources Investigations Report 95-4156, $37 \mathrm{p}$.

Littin, G.R., and Monroe, S.A., 1995b, Results of groundwater, surface-water, and water-chemistry monitoring, Black Mesa area, northeastern Arizona-1994: U.S. Geological Survey Water-Resources Investigations Report 95-4238, 25 p.

Littin, G.R., and Monroe, S.A., 1996, Ground-water, surface-water, and water-chemistry data, Black Mesa area, northeastern Arizona-1995: U.S. Geological Survey OpenFile Report 96-616, 22 p.
Littin, G.R., and Monroe, S.A., 1997, Ground-water, surfacewater, and water- chemistry data, Black Mesa area, northeastern Arizona-1996: U.S. Geological Survey OpenFile Report 97-566, 27 p.

Lopes, T.J., and Hoffmann, J.P., 1997, Geochemical analyses of ground-water ages, recharge rates, and hydraulic conductivity of the N Aquifer, Black Mesa area, Arizona: U.S. Geological Survey Water-Resources Investigations Report 96-4190, 42 p.

McCormack, H.F., Fisk, G.G., Duet, N.R., Evans, D.W., and Castillo, N.K., 2002, Water-resources data for Arizona, water year 2001: U.S. Geological Survey Water-Data Report AZ-01-1, 399 p.

McCormack, H.F., Fisk, G.G., Duet, N.R., Evans, D.W., Roberts, W.P., and Castillo, N.K., 2003, Water-resources data for Arizona, water year 2002: U.S. Geological Survey Water-Data Report AZ-02-1, 337 p.

Smith, C.F., Anning, D.W., Duet, N.R., Fisk, G.G., McCormack, H.F., Pope, G.L., Rigas, P.D., and Wallace, B.L., 1995, Water-resources data for Arizona, water year 1994: U.S. Geological Survey Water-Data Report AZ-94-1, $320 \mathrm{p}$.

Smith, C.F., Boner, F.C., Davis, R.G., Duet, N.R., and Rigas, P.D., 1993, Water-resources data for Arizona, water year 1992: U.S. Geological Survey Water-Data Report AZ-92-1, $360 \mathrm{p}$.

Smith, C.F., Rigas, P.D., Ham, L.K., Duet, N.R., and Anning, D.W., 1994, Water-resources data for Arizona, water year 1993: U.S. Geological Survey Water-Data Report AZ-93-1, $360 \mathrm{p}$.

Smith, C.F., Duet, N.R., Fisk, G.G., McCormack, H.F., Partin, C.K., Pope, G.L., Rigas, P.D., and Tadayon, Saeid, 1996, Water-resources data for Arizona, water year 1995: U.S. Geological Survey Water-Data Report AZ-95-1, 306 p.

Smith, C.F., Duet, N.R., Fisk, G.G., McCormack, H.F., Partin, C.K., Pope, G.L., and Rigas, P.D., 1997, Water-resources data for Arizona, water year 1996: U.S. Geological Survey Water-Data Report AZ-96-1, 328 p.

Sottilare, J.P., 1992, Results of ground-water, surfacewater, and water-quality monitoring, Black Mesa area, northeastern Arizona-1989-90: U.S. Geological Survey Water-Resources Investigations Report 92-4008, 38 p.

Tadayon, Saeid, Duet, N.R., Fisk, G.G., McCormack, H.F., Partin, C.K., Pope, G.L., and Rigas, P.D., 1999, Water-resources data for Arizona, water year 1998: U.S. Geological Survey Water-Data Report AZ-98-1, 454 p. 
Tadayon, Saeid, Duet, N.R., Fisk, G.G., McCormack, H.F., Partin, C.K., Pope, G.L., and Rigas, P.D., 2000, Water-resources data for Arizona, water year 1999: U.S. Geological Survey Water-Data Report AZ-99-1, 389 p.

Tadayon, Saeid, Duet, N.R., Fisk, G.G., McCormack, H.F., Partin, C.K., Pope, G.L., and Rigas, P.D., 2001, Water-resources data for Arizona, water year 2000: U.S. Geological Survey Water-Data Report AZ-00-1, 390 p.

Tadayon, Saeid, Duet, N.R., Fisk, G.G., McCormack, H.F., Pope, G.L., and Rigas, P.D., 1998, Water-resources data for Arizona, water year 1997: U.S. Geological Survey Water-Data Report AZ-97-1, 416 p.

Thomas, B.E., and Truini, Margot, 2000, Ground-water, surface-water, and water-chemistry data, Black Mesa area, northeastern Arizona-1999: U.S. Geological Survey OpenFile Report 00-453, 42

Thomas, B.E., 2002a, Ground-water, surface-water, and waterchemistry data, Black Mesa area, northeastern Arizona2000-2001, and performance and sensitivity of the 1988 USGS numerical model of the N aquifer: U.S. Geological Survey Water-Resources Investigations Report 02-4211, $75 \mathrm{p}$.

Thomas, B.E., 2002b, Ground-water, surface-water, and water-chemistry data, Black Mesa area, northeastern Arizona-2001-02: U.S. Geological Survey Open-File Report 02-485, 43 p.

Truini, Margot, Baum, B.M., Littin, G.R., and ShingoitewaHonanie, Gayl, 2000, Ground-water, surface-water, and water-chemistry data, Black Mesa area, northeastern Arizona-1998: U.S. Geological Survey Open-File Report 00-66, 37 p.

Truini, Margot, and Longsworth, S.A., 2003, Hydrogeology of the D aquifer and movement and ages of ground water determined from geochemical and isotopic analyses, Black Mesa area, northeastern Arizona: U.S. Geological Survey Water-Resources Investigations Report 03-4189, 38 p.

Truini, Margot and Thomas, B.E., 2004, Ground-water, surface-water, and water-chemistry data, Black Mesa area, northeastern Arizona-2002-03: U.S. Geological Survey Open-File Report 03-503, 43 p.

U.S. Department of Agriculture, Natural Resources Conservation Service, 1999, Arizona annual precipitation: Fort Worth, Texas, USDA-NRCS National Cartography \& Geospatial Center, scale 1:1,300,000.

U.S. Environmental Protection Agency, 2002, Current drinking water standards, national primary and secondary drinking water regulations: Washington, D.C., U.S. Environmental Protection Agency, accessed October 21, 2004, at URL http:// www.epa.gov/safewater/mcl.html.
U.S. Geological Survey, 1963-64a, Surface-water records of Arizona: U.S. Geological Survey report.

U.S. Geological Survey, 1963-64b, Ground-water records of Arizona: U.S. Geological Survey report.

U.S. Geological Survey, 1965-74a, Water-resources data for Arizona- Part 1, Surface-water records: U.S. Geological Survey Water-Resources Data Report.

U.S. Geological Survey, 1965-74b, Water-resources data for Arizona- Part 2, Ground-water records: U.S. Geological Survey Water-Resources Data Report.

U.S. Geological Survey 1976-83, Water-resources data for Arizona, water years 1975-81: U.S. Geological Survey Water-Resources Data Reports AZ-75-1 to AZ-81-1.

U.S. Geological Survey 1978, Progress report on Black Mesa monitoring program-1977: U.S. Geological Survey Open-File Report 78-459, 38 p.

White, N.D., and Garrett, W.B., 1984, Water resources data for Arizona, water year 1982: U.S. Geological Survey Water-Data Report AZ-82-1, 440 p.

White, N.D., and Garrett, W.B., 1986, Water resources data for Arizona, water year 1983: U.S. Geological Survey Water-Data Report AZ-83-1, 387 p.

White, N.D., and Garrett, W.B., 1987, Water resources data for Arizona, water year 1984: U.S. Geological Survey WaterData Report AZ-84-1, 381 p.

White, N.D., and Garrett, W.B., 1988, Water resources data for Arizona, water year 1985: U.S. Geological Survey WaterData Report AZ-85-1, 343 p.

Wilson, R.P., and Garrett, W.B., 1988, Water resources data for Arizona, water year 1986: U.S. Geological Survey Water-Data Report AZ-86-1, 341 p.

Wilson, R.P., and Garrett, W.B., 1989, Water-resources data for Arizona, water year 1987: U.S. Geological Survey Water-Data Report AZ-87-1, 385 p.

Zhu, Chen., Waddell, R.K., Star, I., and Ostrander, M., 1998, Responses of ground water in the Black Mesa Basin, northeastern Arizona, to paleoclimatic changes during the late Pleistocene and Holocene: Geology, v. 26, no. 2, p. 127-130.

Zhu, Chen., 2000, Estimate of recharge from radiocarbon dating of groundwater and numerical flow and transport modeling: Water Resources Research, v. 36, no. 9, p. 2607-2620. 
This page left blank intentionally. 


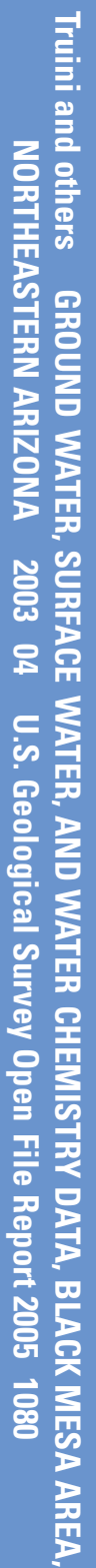

Printed on recycled paper 